Water Operations Technical Support Program

Water Movement in Relation to Fecal Coliform Contamination in the Metro Beach Area of Lake St. Clair, Michigan

Craig S. Smith, William F. James, Harry L. Eakin, and John W. Barko 
The contents of this report are not to be used for advertising, publication, or promotional purposes. Citation of trade names does not constitute an official endorsement or approval of the use of such commercial products.

The findings of this report are not to be construed as an official Department of the Army position, unless so designated by other authorized documents. 
ERDC/EL TR-00-2

February 2000

\section{Water Movement in Relation to Fecal Coliform Contamination in the Metro Beach Area of Lake St. Clair, Michigan}

by Craig S. Smith

Professional Lake Management

8865 100th St. S.E.

Caladonia, MI 49316

William F. James, Harry L. Eakin, John W. Barko

Environmental Laboratory

U.S. Army Engineer Research and Development Center

3909 Halls Ferry Road

Vicksburg, MS 39180-6199

Final report

Approved for public release; distribution is unlimited 


\section{U.S. Army Engineer Research and Development Center Cataloging-in-Publication Data}

Water movement in relation to fecal coliform contamination in the Metro Beach area of Lake

St. Clair, Michigan / by Craig S. Smith... [et al.] ; prepared for U.S. Army Corps of Engineers.

87 p. : ill. ; $28 \mathrm{~cm}$. - (ERDC/EL ; TR-00-2)

Includes bibliographic references.

1. Water - Pollution - Saint Clair, Lake (Mich. and Ont.) 2. Saint Clair, Lake (Mich. and Ont.) 3. Bacteria - Ecology - Saint Clair, Lake (Mich. and Ont.) I. Smith, Craig S. II. United States. Army. Corps of Engineers. III. U.S. Army Engineer Research and Development Center. IV. Environmental Laboratory (U.S.) V. Series: ERDC/EL TR ; 00-2. TA7 E8 no.ERDC/EL TR-00-2 


\section{Contents}

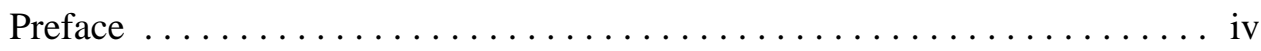

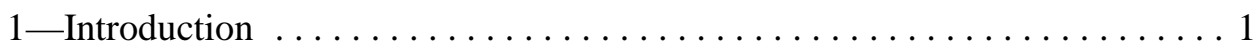

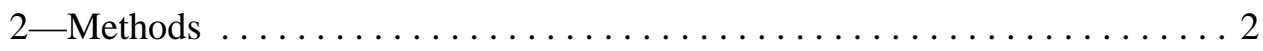

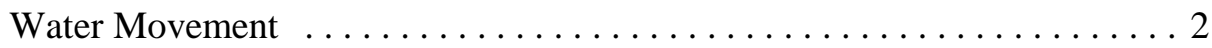

Fecal Coliform Bacteria Sampling $\ldots \ldots \ldots \ldots \ldots \ldots \ldots \ldots \ldots$

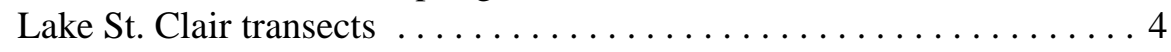

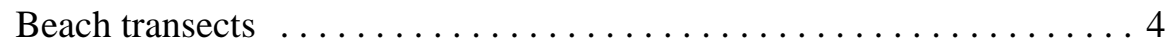

Coliform sampling and enumeration $\ldots \ldots \ldots \ldots \ldots \ldots \ldots \ldots$

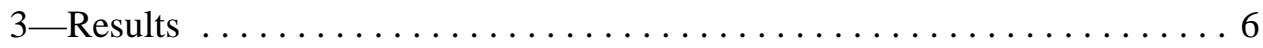

Precipitation and Wind Patterns $\ldots \ldots \ldots \ldots \ldots \ldots \ldots \ldots \ldots \ldots \ldots \ldots \ldots \ldots \ldots$

Dye Cloud Movement and Bacterial Concentrations ...........6 6

1-2 June 1998 ................................. 6

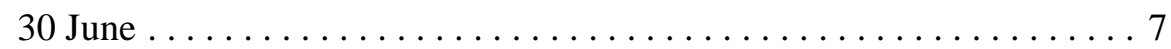

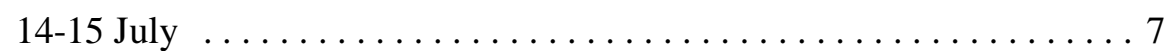

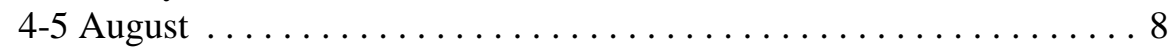

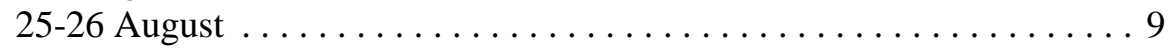

11-12 September . ......................... 10

Water Residence Time Along the Metro Beach ............... 11

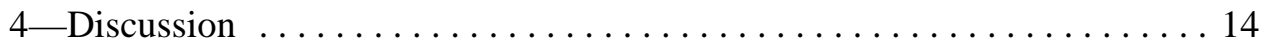

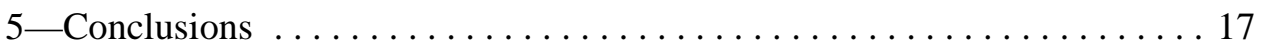

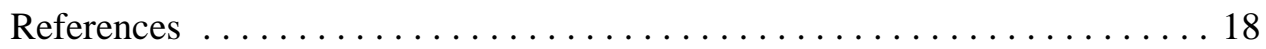

Figures 1-58

SF 298 


\section{Preface}

The work reported herein was conducted as part of the Water Operations Technical Support (WOTS) Program. The WOTS Program is sponsored by the Headquarters, U.S. Army Corps of Engineers (HQUSACE), and is assigned to the U.S. Army Engineer Research and Development Center (ERDC) under the purview of the Environmental Laboratory (EL). Funding was provided under Department of the Army Appropriation 96X3123, Operations and Maintenance. Dr. John W. Barko was Program Manager for the WOTS Program, and Mr. Robert C. Gunkel, Jr. was Assistant Manager. Program Monitors during this study were Mr. Frederick B. Juhle and Mr. Lewis Smith, HQUSACE. This study was also conducted in response to a request from the Huron-Clinton Metropolitan Authority (Detroit, MI).

The study was conducted and the report written by Dr. Craig S. Smith of Professional Lake Management, and Mr. William F. James, Mr. Harry L. Eakin, and Dr. Barko of the Ecosystem Processes and Effects Division (EPED) of the EL, ERDC. We gratefully acknowledge the assistance of Ms. Colette Luff of the USACE District, Detroit, for logistical support, Mr. Steven Ashby for review of this report, Ms. Michele Huppert and Mr. Dale Dressel of AScI Corp., and Mss. Laura Blegen, Brenda Lamb, Emily Schnieder, and Holly Wallace of the Eau Galle Aquatic Ecology Laboratory, ERDC, Spring Valley, WI, for the execution of water movement studies.

This investigation was conducted under the general supervision of Dr. John W. Keeley, Acting Director, EL, and under the direct supervision of Dr. Richard E. Price, Chief, Environmental Processes and Effects Division.

At the time of publication Dr. Lewis E. Link was Acting Director, ERDC, and COL Robin R. Cababa, EN, was Commander.

The contents of this report are not to be used for advertising, publication, or promotional purposes. Citation of trade names does not constitute an official endorsement or approval of the use of such commercial products. 


\section{Introduction}

In 1994, frequent periods of unacceptably high fecal coliform levels in the Metro Beach and Memorial Beach areas of Lake St. Clair, coupled with thick floating mats of decomposing aquatic vegetation, led to beach closures and the loss of millions of dollars in recreational revenue. Since then, beach closures have continued to be a problem at Metro Beach and several other nearby beaches. Although the origin of the waterborne fecal coliform bacteria has not been identified, it has been postulated that combined sewer overflows (CSO) into the Clinton River during storm events result in a plume of contaminated water that enters the lake through the Clinton River cutoff (located $\sim 3 \mathrm{~km}$ to the west of the Metro Beach area). When these flows occur during periods of southwesterly or westerly winds, water circulation from the cutoff to Metro Beach could result in bacterial contamination of the beach. Based on plant populations observed in 1994 and 1995 (U.S. Army Corps of Engineers 1996), it has also been suggested that dense submersed aquatic plant growth may restrict water movement in the Metro Beach area, thereby increasing water residence times in sheltered shoreline regions and retaining contaminated water in these areas.

The objectives of this investigation were to determine (1) the source of fecal coliform bacteria contaminating the Metro Beach area and (2) how likely it is that water currents could move contaminated water from the Clinton River cutoff into the Metro Beach Area rapidly enough and with sufficiently limited dilution that bacteria from this source would exceed state standards for body contact recreation. To address these connections, investigations of bacterial concentrations and water movements were conducted seasonally by employing fluorescent dye as a tracer of water movement. 


\section{Methods}

\section{Water Movement}

Rhodamine WT, a red fluorescent dye, was used as a tracer for monitoring water movement near the Metro Beach area of Lake St. Clair. Dye tracer studies were conducted during the weeks of 1 June, 13 July, 3 August, 24 August, and 7 September 1998. On all dates, dye was injected into the upper $1 \mathrm{~m}$ of the water column along transects established near the Clinton River cutoff and the Metro Beach area (Figure 1). The injection transects were perpendicular to the shoreline and approximately $600 \mathrm{~m}$ in length. During the dye tracer study conducted during the week of 1 June, an additional transect was established between the Clinton River cutoff and the Metro Beach area (Figure 1).

During the morning of each dye study, approximately $3.25 \mathrm{~L}$ of concentrated dye $\left(2.4 \times 10^{8} \mathrm{ppm}\right)$ were diluted with $200 \mathrm{~L}$ of lake water prior to injection for each transect. Using an impeller pump, the dye slurry was injected into the water through a 1-m-long dye injector hose that had a series of holes interspersed throughout it. The dye was injected into the upper $1 \mathrm{~m}$ of the water column at a constant rate by making three to four passes over the transect with a boat traveling at $5 \mathrm{~km} / \mathrm{h}$ (i.e., 7 minutes per pass). During each pass, the dye cloud was gently mixed by the boat motor action to homogenize the dye throughout the upper $1 \mathrm{~m}$ of the water column. Injection of all of the dye along a transect was achieved in less than $30 \mathrm{~min}$. Immediately after injection, each dye cloud was approximately $600 \mathrm{~m}$ long by $10-20 \mathrm{~m}$ wide. The target concentration of dye after injection was $\sim 100 \mathrm{ppb}$. Thus, the dye cloud was clearly visible for a number of hours after injection.

Dye cloud movement from each transect was tracked at $\sim 2 \mathrm{hr}$ intervals over a 12- to 24-hr period. To characterize the size and movement of the dye cloud as a function of time, a series of sampling transects were established through the dye cloud, based on visual approximation of the size of the cloud. Two transects were located along the leading edges of the cloud, and one transect was established through the approximate center of it (Figure 2). Two additional transects were established just beyond the visible bounds of the cloud to characterize the extent of the leading edges. Along each sampling transect, five to seven stations were sampled for determination of dye concentrations. The location of each 
sampling station was determined using a differential global positioning system (dGPS; Micrologic Model ML-250).

At each station, a sample of the upper $1 \mathrm{~m}$ of the water column was collected using an integrated sampler (Barko et al. 1981), which consisted of a 1.5-in. (0.0381-m) PVC pipe with a one-way check valve attached to the base of the pipe. When the pipe was lowered into the water column down to the 1-m depth, the check valve remained open, allowing water to pass freely through the pipe. When the sampler was raised from the water column, the check valve closed, trapping a water sample integrated over the upper 1-m depth. Samples were carefully poured into a rinsed bucket, gently mixed, and subsampled for fluorometric analysis.

Dye concentrations were measured using a Turner Designs Fluorometer (10-005R) that was calibrated using known dye standards. The position, extent, and movement of dye clouds through time were graphically determined using the contour mapping software SURFER (Golden Software 1997).

In addition to dye tracer studies, dye dissipation (residence time) studies were conducted for water located along the Metro Beach during the weeks of 3 and 24 August and 7 September. A dye streak measuring approximately $800 \mathrm{~m}$ long by $5 \mathrm{~m}$ wide was injected along the beach area on these dates. Reference points were established along the beach at 100-m intervals for dye concentration and bacteria determinations (Table 1). The Universal Transverse Mercator (UTM) coordinates of the reference points were determined by dGPS, and water samples for dye concentration determination were collected just offshore from these reference points (at about $2 \mathrm{~m}$ offshore). Short-term (hourly) changes in concentration were monitored over a 6- to 24 -hr period on each date.

\begin{tabular}{||l|l|l||}
\hline \hline \multicolumn{2}{|l|}{$\begin{array}{l}\text { Table 1 } \\
\text { Locations of Beach Sampling Reference Points for Bacterial } \\
\text { Sampling }\end{array}$} & \multicolumn{2}{|c|}{ UTM Coordinates } \\
\cline { 2 - 4 } Location & East & North \\
\hline \hline C0 & 352280 & 4714664 \\
\hline C1 & 352375 & 4714670 \\
\hline C2 & 352470 & 4714680 \\
\hline C3 & 352559 & 4714666 \\
\hline C4 & 352687 & 4714553 \\
\hline C5 & 352754 & 4714520 \\
\hline C6 & 352846 & 4714490 \\
\hline C7 & 352939 & 4714462 \\
\hline C8 & 352998 & 4714437 \\
\hline \hline 11927 North American Datum & & \\
\hline
\end{tabular}


Wind speed and direction were monitored continuously during each study using a logging weather station deployed at Metro Beach. A 3-cup anemometer and wind vane (DataLoggers Model ES-055; range $=0-175 \mathrm{mph}$; Threshold $=1.1$ $\mathrm{mph}$; Accuracy $=2 \%$ ) were positioned on a pole approximately $2 \mathrm{~m}$ in elevation above the beach. Wind speed and direction were averaged over 5-min intervals every $15 \mathrm{~min}$ for the duration of each study using a data logging system (DataLoggers Model ES-824).

\section{Fecal Coliform Bacteria Sampling}

\section{Lake St. Clair transects}

Based on an initial sampling grid established for dye studies, bacterial sampling transects perpendicular to the shore were located at intervals from just west of the Clinton River spillway to just east of Black Creek (Figure 3). Along each transect, samples were collected at distances of approximately 100, 300, and 700-1000 m from shore. Bacterial sampling stations were located in the field by their UTM coordinates (Table 2) using dGPS. A sample was also taken from the mouth of the Clinton River spillway. Beginning in August, as mounting evidence indicated that bacterial contamination might be a localized nearshore phenomenon, an additional nearshore sampling location was added to each transect. Nearshore samples were collected along the transect lines as close to shore as samples could be collected from a boat. Samples were collected from lake transects on 1 June, 30 June, 14 July, 4 August, 26 August, and 13 September 1998. Except for the 30 June sampling date, bacterial sampling was coordinated with water movement studies.

\section{Beach transects}

During water residence time studies, bacterial concentrations were sampled along a series of transects located off the Metro beach swimming area (Figure 3). These transects extended perpendicular to the shoreline just offshore from the reference points used in the dye dissipation studies. Samples were collected along each transect as described below at locations with water depths of approximately $2.5,15,30$, and $90 \mathrm{~cm}(1$ in., 6 in., $1 \mathrm{ft}$, and $3 \mathrm{ft})$.

\section{Coliform sampling and enumeration}

Bacterial samples were collected in sterile 100-mL containers by immersing the inverted containers to elbow depth and then turning them right-side up and allowing them to fill. Where the water depth was too shallow for this technique (i.e., the $2.5-\mathrm{cm}$ samples on beach transects), water was collected using a sterile 60-mL syringe, which was then used to fill the sterile sample containers.

Concentrations of Escherichia coli (E. coli) in the samples were determined by National Environmental Testing, Inc., of Pontiac, MI. 


\begin{tabular}{|c|c|c|}
\hline \multicolumn{3}{|c|}{$\begin{array}{l}\text { Table } 2 \\
\text { Locations of Lake St. Clair Bacteria Sampling Sites }\end{array}$} \\
\hline \multirow[b]{2}{*}{ Location } & \multicolumn{2}{|c|}{ UTM Coordinates $^{1}$} \\
\hline & East & North \\
\hline \multicolumn{3}{|l|}{ T1-0 } \\
\hline T1-1 & 348500 & 4713201 \\
\hline T1-2 & 348700 & 4713000 \\
\hline T1-3 & 349100 & 4712601 \\
\hline \multicolumn{3}{|l|}{ T2-0 } \\
\hline T2-1 & 348900 & 4713600 \\
\hline T2-2 & 349100 & 4713400 \\
\hline T2-3 & 349500 & 4713000 \\
\hline \multicolumn{3}{|l|}{ T3-0 } \\
\hline T3-1 & 350200 & 4714400 \\
\hline T3-2 & 350200 & 4714200 \\
\hline T3-3 & 350200 & 4713800 \\
\hline \multicolumn{3}{|l|}{$\mathrm{T} 4-0$} \\
\hline T4-1 & 351600 & 4714500 \\
\hline T4-2 & 351600 & 4714300 \\
\hline T4-3 & 351600 & 4713900 \\
\hline \multicolumn{3}{|l|}{ T5-0 } \\
\hline T5-1 & 352800 & 4714400 \\
\hline T5-2 & 352800 & 4714200 \\
\hline T5-3 & 352800 & 4713800 \\
\hline \multicolumn{3}{|l|}{ T6-0 } \\
\hline T6-1 & 353673 & 4714041 \\
\hline T6-2 & 353901 & 4713800 \\
\hline T6-3 & 354035 & 4713721 \\
\hline
\end{tabular}




\section{Results}

\section{Precipitation and Wind Patterns}

Mean daily flow for the Clinton River near Fraser, MI, exhibited peaks exceeding 1000 cubic feet per second (cfs) in April and early May (Figure 4). Elevated flows were also observed in late May, early and mid-July, and early August. In particular, the largest storm inflow during the summer of 1998 occurred on 6 August ( $2510 \mathrm{cfs}$ ). In contrast, flows were low for extended periods in mid- to late June, late July, and mid-August through September. Average flow for the summer period (April through September) of 1998 was 320 cfs. This value was slightly lower than average summer flows of $356 \mathrm{cfs}$, based on a 50-year record (Figure 5).

During April through September 1998, winds blew most frequently out of the northwest (NW) and southwest (SW) (Figure 6). Winds blew out of the southeast (SE) $21 \%$ of the time and out of the northeast (NE) $17 \%$ of the time. Wind speeds averaged $\sim 7.5 \mathrm{mph}$ over all wind directions $(\mathrm{NW}=7.1 \mathrm{mph}$, $\mathrm{SW}=7.8 \mathrm{mph}, \mathrm{SE}=7.3 \mathrm{mph}, \mathrm{NE}=7.4 \mathrm{mph}$ ). Mean daily wind speeds during summer 1998 fluctuated between $\sim 3$ and $15 \mathrm{mph}$ (Figure 7).

\section{Dye Cloud Movement and Bacterial Concentrations}

\section{1-2 June 1998}

From midnight to 1100 hours on 1 June, winds blew steadily from the northnorthwest (NNW) at approximately $7 \mathrm{mph}$ (Figure 8). Between 1115 and 2400 hours, wind velocity increased and shifted to the east-southeast (ESE). Shortly before the study, precipitation occurred in the region, resulting in elevated flow in the Clinton River on 31 May and 1 June (Figure 4). Mean daily flows were $524 \mathrm{cfs}$ on 31 May and $288 \mathrm{cfs}$ on 1 June. Dye was injected along three transects in the Metro Beach area between 0700 and 0800 hours on 1 June (Figure 9). In general, all dye clouds were strongly influenced by wind-driven currents. The dye cloud deployed near the Metro Beach area moved in a SE 
direction between 0700 and 1300 as a result of wind shear. During this time period, the southern edge of the cloud moved more than $600 \mathrm{~m}$. Dye clouds located near the Clinton River cutoff and in the middle of the study area also initially moved in a SE direction from 0700 until 1300 on 1 June. The dramatic shift in winds to the south-southeast (SSE) direction at noon caused dye clouds to reverse direction and move NW toward the shore. Sampling of dye clouds located near the Clinton River cutoff and in the middle of the study area shortly after the wind shift demonstrated movement in a NW direction toward the shore. In particular, the dye cloud located near the Clinton River cutoff moved in a southerly direction during the morning of 1 June, but then moved back to the NW by the time of sampling (1300 hours).

Bacterial concentrations were uniformly low throughout the Lake St. Clair sampling grid (Figure 10). In most locations the E. coli concentration was below the detection limit of 10 colony-forming units $(\mathrm{CFU}) / 100 \mathrm{~mL}$. A few isolated locations had E. coli concentrations of 10 or $20 \mathrm{CFU} / 100 \mathrm{~mL}$. No location had an E. coli concentration above $20 \mathrm{CFU} / 100 \mathrm{~mL}$.

\section{June}

Bacterial concentrations were measured along the Lake St. Clair transects on 30 June (Figure 11). No dye movement studies were conducted on this date. Concentrations of E. coli were slightly elevated (i.e., 10-50 CFU/100 mL) at the shoreward end of the transects and decreased to levels below the detection limit at the outer end of the transects. The only sample having an $E$. coli concentration above $100 \mathrm{CFU} / 100 \mathrm{~mL}$ was collected at the shoreward end of the transect just east of the Clinton River cutoff channel. This sample had an E. coli concentration of $140 \mathrm{CFU} / 100 \mathrm{~mL}$

\section{4-15 July}

Between 1200 and 2000 hours on 14 July, wind speeds averaged $11 \mathrm{mph}$ out of the SSE (Figure 12). Wind speed diminished to near 0 mph between 2030 and 2200 hours, increased to near $10 \mathrm{mph}$ out of the south-southwest (SSW) at 2300 hours, then declined to minimal speeds after midnight on 15 July. Six days (i.e., on 8 July 1998) prior to injection of dye clouds in the Metro Beach area, a storm event resulted in a peak flow of $1040 \mathrm{cfs}$ for the Clinton River (Figure 4). Flows quickly declined and returned to nominal levels several days before dye injection. Flows were nominal during the dye study on 14 July 1998.

Dye streaks were injected in the surface waters along transects established near the Metro Beach area and the Clinton River cutoff between 1130 and 1300 hours on 14 July (Figure 13). Near the Metro Beach area, the dye cloud moved along a NW trajectory away from the swimming beach, reflecting wind direction (Figures 14 through 16). Trajectory speed during the afternoon of $14 \mathrm{July}$, determined for the center of mass of the dye cloud, averaged $\sim 2 \mathrm{~cm} / \mathrm{s}$. 
Twenty-four hours after dye injection, the dye cloud deployed near the Metro Beach area had moved $>1000 \mathrm{~m}$ away from its original position (Figure 17).

The dye streak injected near the Clinton River cutoff exhibited a complex dispersion pattern during the afternoon of 14 July (Figures 14 through 17). The southern leading edge of the cloud moved in a SSW direction toward Detroit during that afternoon. At 1900 hours this edge of the dye cloud had moved nearly $500 \mathrm{~m}$ from its original position (Figure 16). In contrast the northern leading edge of the dye cloud moved back into shore along a NE trajectory and became trapped along a break wall that was located to the east of the mouth of the Clinton River cutoff. These patterns suggested the occurrence of some eddying of water near the cutoff region under southerly winds.

Bacterial concentrations were measured along the Lake St. Clair transects on 14 July (Figure 18). Concentrations of E. coli were below the detection limit everywhere except along the transect just west of the Clinton River cutoff channel. Samples collected along this transect had E. coli concentrations of 20 to $50 \mathrm{CFU} / 100 \mathrm{~mL}$

\section{4-5 August}

On 4 August, wind speed was nearly constant at $6.3 \mathrm{mph}$ out of the SE during the afternoon (Figure 19). Wind direction shifted to the E and north-northeast (NNE) between 2100 hours on 4 August and 1200 hours on 5 August. Flows via the Clinton River were < 100 cfs between 27 July and 4 August (Figure 4). Elevated flows from the Clinton River occurred on 22 July and averaged $656 \mathrm{cfs}$ over a 24 -hr period.

Dye clouds injected near the Metro Beach area and the Clinton River cutoff between 1130 and 1300 hours on 4 August followed trajectories similar to those observed on 14 July (Figures 20-24). Near the Metro Beach area, the dye cloud moved in a NW direction away from the beach during the afternoon of 4 August. Like dye cloud movement on 14 July, the trajectory speed on 4 August was $\sim 2 \mathrm{~cm} / \mathrm{s}$. Sustained winds from the SSE and east (E) during the night of 4 August and morning of 5 August resulted in dispersion and movement of the dye cloud toward the Clinton River cutoff (Figure 24). The leading edge of the dye cloud moved $2100 \mathrm{~m}$ from its original injection transect by 1030 hours on 5 August.

The dye streak injected near the Clinton River cutoff moved in a northerly direction on 4 August. In particular, some of the dye cloud moved considerably north into the Clinton River cutoff throughout the afternoon of 4 August (Figure 22). As on 14 July, much of the dye cloud also eddied along the break wall located east of the mouth of the Clinton River cutoff during 4 August. On the morning of 5 August, the shift in wind direction during the night out of the NE appeared to be associated with movement of some of the dye cloud along a southern trajectory (Figure 24). Much of the dye trapped along the break wall moved south by the morning of 5 August. There was also considerable 
movement of dye upstream into the Clinton River cutoff by the morning of 5 August.

Bacterial concentrations were measured along the Lake St. Clair transects on 4 August (Figure 25). This sampling date was the first occasion when additional sampling locations close to shore were added to the transects. Concentrations of E. coli were slightly elevated (i.e., $10-30 \mathrm{CFU} / 100 \mathrm{~mL}$ ) at the shoreward end of the transects and decreased to levels below the detection limit at the outer end of the transects. No sample had an E. coli concentration above $30 \mathrm{CFU} / 100 \mathrm{~mL}$, and concentrations of $30 \mathrm{CFU} / 100 \mathrm{~mL}$ were encountered only in the Clinton River cutoff channel and the nearshore sample just east of the Metro Beach swimming area.

\section{5-26 August}

During the afternoon of 25 August, winds blew steadily out of the west at $\sim 6 \mathrm{mph}$ between 1200 hours and 1800 hours (Figure 26). Peaks in wind speed near $10 \mathrm{mph}$ out of the west occurred at 1400 hours. Between 1800 hours on 25 August and 0900 hours on 26 August, wind speed decreased to a mean 2.9 out of the NNW. Shortly before noon on 26 August, wind direction shifted to the $\mathrm{NNE}$ and east with wind speeds averaging $5.1 \mathrm{mph}$. Before dye injection, mean daily flows from the Clinton River were $<150$ cfs between 20 and 24 August. On the day of dye injection (25 August, see below), mean daily flows increased slightly to 312 cfs. Mean daily flow declined to nominal levels on 26 August.

A 600-m-long dye streak was injected near the Metro Beach area at $\sim 1300$ hours on 25 August (Figure 27). Injection of the second dye streak near the Clinton River cutoff was postponed until 26 August at 1200 hours, due to elevated wind speeds and high waves during the afternoon of 25 August.

The trajectory of the dye cloud on 25 August was clearly influenced by winds blowing out of the west, as it moved in an easterly direction, parallel to the shoreline of the Metro Beach area (Figures 27-31). By 1830 hours, its center of mass had moved directly east over $200 \mathrm{~m}(\sim 2 \mathrm{~cm} / \mathrm{s})$. At 1100 hours on 26 August, the southern portion of the dye cloud moved in a southerly direction, coincident with winds blowing out of the NW and NE during the evening of 25 August. At that particular time the dye cloud was $\sim 1100 \mathrm{~m}$ long and $600 \mathrm{~m}$ wide.

Due to shifts in wind direction to the NE during the afternoon of 26 August, the dye cloud deployed near the Clinton River cutoff moved in a SW direction (Figures 32-35). By 1600 hours on 26 August, the southern edge of the dye cloud had moved nearly $1000 \mathrm{~m}$ from its original injection point. The northern edge of the dye cloud dispersed toward the shoreline and toward the break wall located east of the mouth of the cutoff.

Bacterial concentrations were measured along the Lake St. Clair transects on 26 August (Figure 36). On this date concentrations of E. coli were below the 
detection limit everywhere except in and around the mouth of the Clinton River cutoff and near the shore at Metro Beach. The E. coli concentration in the cutoff channel was $880 \mathrm{CFU} / 100 \mathrm{~mL}$. Concentrations between 10 and $100 \mathrm{CFU} /$ $100 \mathrm{~mL}$ were encountered in all but the outermost locations along the transects on both sides of the channel. The two locations on the shoreward end of the transect just east of the Metro Beach swimming area had E. coli concentrations of 170 and 20. No location between the cutoff channel and the beach had an E. coli concentration above the detection limit.

\section{1-12 September}

Similar to wind patterns observed during the afternoon of 25 August, winds blew from a westerly direction on 11 September (Figure 37). Wind speeds during this period averaged $\sim 13 \mathrm{mph}$. Winds continued to blow from the west and SW throughout the afternoon and evening of 11 September and until $\sim 1500$ hours on 12 September. Wind direction shifted to the NNE over a 6-hour period during the evening of 12 September. Wind speeds out of the north declined substantially during the early morning of 13 September. During the study period, mean daily flows from the Clinton River cutoff were nominal with the exception of a minor peak of $227 \mathrm{cfs}$ that occurred on 2 September (Figure 4).

A dye cloud was injected at the Clinton River cutoff region at 1130 hours on 11 September (Figure 38). During the afternoon of 11 September, movement of dye exhibited a complex spatial pattern (Figures 38-41). The southern portion of the dye cloud followed an easterly and NE trajectory, coinciding with wind direction that afternoon. However, the northern portion of the dye cloud, located near the mouth of the Clinton River cutoff, both remained near the shoreline region and dispersed south slightly along the shoreline west of the cutoff region. By 0930 hours on 12 September (Figure 42), the dye cloud had split, with one portion moving along an east and NE trajectory toward the Metro Beach area and another portion remaining near the cutoff area. These results suggest that near the shoreline on the leeward side of the wind, wind-generated currents were slight, while further out into the lake, where wind speeds and waves were noticeably stronger, wind-generated currents were resulting in water movement toward the beach.

Continued sustained winds out of the west on 12 September resulted in movement of a second dye cloud, deployed near the Metro Beach area at 1000 hours on 12 September, toward the beach area during the afternoon (Figures 43-46). The center of mass of the dye cloud moved over $300 \mathrm{~m}$ between 1000 and 1630 hours, for an estimated velocity of $1 \mathrm{~cm} / \mathrm{s}$. The eastern leading edge of the dye cloud reached the western edge of the beach area by 1630 hours. A shift in wind direction toward the north and NE between 1500 hours and 2100 hours on 12 September resulted in movement of the southern portion of the dye cloud along a NW trajectory back toward the original injection transect. By 0900 hours on 13 September (Figure 47), the dye cloud appeared to have split due to shifting wind direction during the previous day. 
One portion of the dye cloud appeared to continue to follow a NW trajectory during that evening and was located along the shoreline to the west of the Metro Beach area on the morning of 13 September. Another portion of the dye cloud appeared to continue to move toward the NE and was tracked to the shoreline east of the Metro Beach area on the morning of 13 September.

Bacterial concentrations were measured along the Lake St. Clair transects on 13 September (Figure 48). On this date concentrations of $E$. coli were below the detection limit everywhere except in two locations along the transect just west of the Clinton River cutoff. The E. coli concentrations in these locations were 20 to $40 \mathrm{CFU} / 100 \mathrm{~mL}$. No other locations had E. coli concentrations above the detection limit.

\section{Water Residence Time Along the Metro Beach}

On 5 August, dye streaks were deployed directly along the shoreline area just to the east of the beach to observe dissipation. Sampling station locations are shown in Figure 49. During the late morning and early afternoon of 5 August, winds were blowing from the east at $\sim 8 \mathrm{mph}$ (range=5.9 $-10.4 \mathrm{mph}$ ). Concentrations of dye in the middle of the transect were $\sim 500 \mathrm{ug} / \mathrm{L}$ shortly after injection. The dye cloud dissipated very rapidly, as concentrations declined to near zero about 3 hours after injection (Figure 50), suggesting substantial water exchange. The dye cloud traveled rapidly along a westerly trajectory through the beach area and toward the Clinton River cutoff during the afternoon of 5 August.

Bacterial concentrations on 5 August generally decreased from west to east and outwards from the shore (Figure 51). The highest E. coli concentrations were observed 200 to $400 \mathrm{~m}$ east and slightly offshore $100 \mathrm{~m}$ east of the western end of the beach. In these locations, bacterial counts exceeded $2500 \mathrm{CFU} /$ $100 \mathrm{~mL}$ (Table 3). Samples collected at the two locations nearest to shore on each transect exceeded the single-sample threshold of $300 \mathrm{CFU} / 100 \mathrm{~mL}$ for body contact recreation (e.g., swimming) in nearly every location, and many samples exceeded $1000 \mathrm{CFU} / 100 \mathrm{~mL}$.

On 25 August, a dye cloud was injected along the shoreline east of the beach area at $\sim 1230$ hours (Figure 52). Average wind speeds during the afternoon were $\sim 6 \mathrm{mph}$ (range $=3.6-9.6 \mathrm{mph}$ ) from the west. Dissipation again occurred very rapidly as dye concentrations in the middle of the transect became diluted within an hour of initial injection (Figure 53). The dye cloud moved toward the peninsula located to the east of the beach area on this date.

Bacterial concentrations on 25 August generally decreased from east to west and outwards from the shore (Figure 54). The highest $E$. coli concentrations were observed near the shore at the east end of the beach. In these locations, bacterial counts exceeded $5000 \mathrm{CFU} / 100 \mathrm{~mL}$ (Table 3). Some of the samples collected along the two westernmost transects were below the single-sample threshold of $300 \mathrm{CFU} / 100 \mathrm{~mL}$ for body contact recreation (e.g., swimming), but 


\begin{tabular}{|c|c|c|}
\hline \multicolumn{3}{|c|}{$\begin{array}{l}\text { Table } 3 \\
\text { Bacterial Concentrations Measured in the Beach Area }\end{array}$} \\
\hline \multirow[b]{2}{*}{ Location } & \multicolumn{2}{|c|}{ E. coli CFU/100 mL } \\
\hline & 5-Aug & 25-Aug \\
\hline 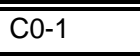 & 1440 & 20 \\
\hline $\mathrm{C} 0-2$ & 1770 & 30 \\
\hline $\mathrm{C} 0-3$ & 1890 & 10 \\
\hline $\mathrm{CO}-4$ & 1220 & 10 \\
\hline C1-1 & 1800 & 260 \\
\hline C1-2 & 7100 & 430 \\
\hline C1-3 & 1400 & 250 \\
\hline C1-4 & 1800 & 100 \\
\hline C2-1 & 4700 & 600 \\
\hline C2-2 & 2100 & 1200 \\
\hline C2-3 & 3000 & 580 \\
\hline C2-4 & 1300 & 330 \\
\hline C3-1 & 2600 & 800 \\
\hline C3-2 & 2300 & 540 \\
\hline C3-3 & 1800 & 550 \\
\hline C3-4 & 900 & 800 \\
\hline C4-1 & 4700 & 1200 \\
\hline C4-2 & 1000 & 300 \\
\hline C4-3 & 1900 & 480 \\
\hline C4-4 & 700 & 390 \\
\hline C5-1 & 1800 & 2700 \\
\hline C5-2 & 1400 & 600 \\
\hline C5-3 & 500 & 1500 \\
\hline $\mathrm{C} 5-4$ & 50 & 900 \\
\hline C6-1 & 200 & 3500 \\
\hline C6-2 & 700 & 3600 \\
\hline C6-3 & 400 & 2400 \\
\hline C6-4 & $<10$ & 2700 \\
\hline C7-1 & 850 & 8000 \\
\hline $\mathrm{C} 7-2$ & 770 & 6000 \\
\hline C7-3 & 700 & 3500 \\
\hline $\mathrm{C} 7-4$ & $<10$ & 3200 \\
\hline C8-1 & 470 & 6500 \\
\hline C8-2 & 300 & 7000 \\
\hline C8-3 & 120 & 3200 \\
\hline C8-4 & 10 & 2300 \\
\hline
\end{tabular}


all samples from the other transects exceeded $300 \mathrm{CFU} / 100 \mathrm{~mL}$. Many samples had $E$. coli concentrations above $1000 \mathrm{CFU} / 100 \mathrm{~mL}$.

On 11 September, winds were blowing steadily from the west during the dye dissipation study conducted along the beach shoreline area. Dye was injected along the shoreline at $\sim 1000$ hours on this date. As with other dissipation studies, the dye cloud rapidly dissipated, as concentrations in the middle of the dye cloud declined to near zero ug/L within 1.5 hours (Figures 55 and 56).

Bacterial samples were not collected in conjunction with the 11 September dye dissipation study. 


\section{Discussion}

Based on the dye tracer studies conducted in 1998, water currents in the part of Lake St. Clair between Metro Beach and the Clinton River cutoff were predominantly driven by wind direction and speed. Winds blowing out of the north and northwest resulted in water movement toward the south, away from the beach. Easterly and southeasterly winds caused water circulation in a westerly direction, from the beach toward the Clinton River cutoff. Winds blowing out of the west and southwest resulted in water circulation that followed an easterly trajectory toward the beach area. During the summer of 1998, winds blew out of the westerly wind rose (i.e., NW and SW wind rose) $62 \%$ of the time; thus water movement from the mouth of the cutoff toward Metro Beach would have been expected to dominate circulation patterns from April until September.

Wind patterns observed in the summer of 1998 were typical of those reported for this area. Based on analysis of long-term wind data collected at Selfridge Air National Guard Base, located 10 miles north of the Metro Beach area, Fox (1998) reported that winds generally blew out of the SSW during the summer. During the summer of 1998, average wind direction was out of the SW. Monthly wind speeds during May through August 1998 ranged from 6.4 to $7.5 \mathrm{mph}$, slightly lower than the long-term average of 8.7 to $11.5 \mathrm{mph}$ (Fox 1998).

One possible source of fecal coliform contamination in the Metro Beach area was contaminated Clinton River water from the cutoff, transported to the beach by water currents circulating from the cutoff toward the beach due to winds blowing out of the westerly wind rose. In order for this mechanism to operate, three conditions must be met: (1) the Clinton River cutoff must carry water with a high concentration of bacteria, (2) the flow of contaminated water from the Clinton River cutoff must be sufficient to produce a mass of contaminated water in the lake, and (3) water circulation must move the contaminated water mass from the cutoff to the beach rapidly enough so that the bacteria remain viable.

These conditions were rarely met during the summer of 1998. Bacterial concentrations in the vicinity of the cutoff were relatively low on all sampling dates. No significant plumes of bacterially contaminated water were observed in the vicinity of the cutoff or moving from the cutoff toward Metro Beach. Mean summer flow from the Clinton River in 1998 was slightly below the average determined over a 50-year period, and there were several relatively long periods 
of low flow (i.e., 2- to 3-week periods) in July, August, and September. Concentrations of $E$. coli measured in the cutoff by the Macomb County Health Department were also relatively low (Figure 57). The E. coli count exceeded $1000 \mathrm{CFU} / 100 \mathrm{~mL}$ on 9 and 10 March, 6 and 10 August, and 8 September. Counts exceeded $2500 \mathrm{CFU} / 100 \mathrm{~mL}$ only on 6 and 10 August.

Observed water movement from the Clinton River cutoff toward the beach area was rapid under westerly wind conditions, as illustrated for conditions on 11-13 September 1998 (see Figures 38-42), when water movement was traced from the mouth of the Clinton River cutoff to the Metro Beach area over a twoday period. Through a comparison of the daily wind rose with periods of elevated flow from the Clinton River and E. coli counts above $1000 \mathrm{CFU} /$ $100 \mathrm{~mL}$ in the cutoff, elevated flow and bacterial counts were found to coincide with winds blowing from the NW or SW only between 6 and 8 August. Thus, if the Clinton River cutoff were a substantial source of bacteria contamination in the beach area, a pulse of high bacterial concentration to within a day or two of the above dates would have been likely. In fact, bacterial counts measured at the beach by the Macomb County Health Department during this period were lower than in the weeks before or after this storm (Figure 58).

Despite low flows from the Clinton River cutoff and low bacterial concentrations in the area between the cutoff and Metro Beach, E. coli concentrations were often elevated in the immediate vicinity of the beach. Bacterial concentrations along the beach transects were consistently highest close to shore, suggesting that bacteria were entering the lake from the beach. Bacterial concentration patterns observed near the beach during dye studies indicated relatively low bacterial concentrations in the water on the upstream end of the beach, and higher concentrations toward the downstream end of the beach. This pattern suggests that relatively clean water from the lake was becoming contaminated as it passed by the beach.

Relatively high levels of bacterial contamination in the beach area were attained despite the brief residence time of water in the area, indicating that the beach must be a substantial source of bacteria. Water ponded on the beach after rainstorms contained extremely high concentrations of $E$. coli (Aquest Corporation, Flint, Michigan, unpublished data), indicating that the beach itself is highly contaminated with E. coli. The source of bacteria contaminating the beach was not positively identified, but large numbers of gulls and geese congregate on the beach at night, and their droppings are the most likely source.

Although the frequency of beach closings due to elevated bacterial counts became a major concern in 1994 when abundant submersed plant growth was also a problem, there is little reason to believe that submersed plant growth is currently an important factor contributing to elevated bacterial counts at Metro Beach. In 1994, large amounts of plant material accumulated in the Metro Beach area to the extent that plant biomass may have severely impeded water circulation. Submersed plant growth may also have impacted water circulation in 1995, when Eurasian watermilfoil (Myriophyllum spicatum) growth on the sandbar offshore from Metro Beach nearly reached the surface. In 1998, 
although submersed plants were abundant throughout much of the area off Metro Beach, most of the plant growth consisted of low-growing species such as wild celery (Vallisneria americana). Even on the offshore sandbar, little of the plant biomass extended into the upper $3 \mathrm{ft}$ of the water column. Thus the impact of submersed plant growth on water circulation was probably minimal.

Below-average precipitation and extended dry periods in 1998 represent conditions that were less favorable for loading of fecal coliform bacteria via the Clinton River cutoff than in years such as 1994, when fecal coliform bacterial contamination was prevalent. During conditions leading to more frequent CSO overflows and greater flow from the Clinton River cutoff, the contribution of bacteria from the cutoff to problems at Metro Beach might be considerably greater than in 1998. 


\section{Conclusions}

The results of this study provide very strong evidence that bacterial contamination of the beach at Metro Beach is an important source of bacterial contamination in the swimming area. During the summer of 1998, E. coli contamination was frequent in the beach area, despite few occasions conducive to the transport of bacteria from the Clinton River. No plumes of contaminated water were observed between the cutoff and the beach, yet $E$. coli concentrations in the Metro Beach swimming area frequently exceeded state standards for fullbody contact recreation. Bacterial concentrations in the beach area were consistently highest near the shore and increased as water moved alongshore past the beach, suggesting that the beach itself is a major source of bacterial contamination. Extremely high counts of $E$. coli in water ponded on the beach following rainstorms suggest that the beach sand is highly contaminated, probably due to droppings from gulls and geese that congregate on the beach. High bacterial counts in the beach area occurred despite a relatively short water residence time in the area, thus contamination problems are more the result of high levels of contamination on the beach than inadequate water movement in the area.

During periods of sustained winds coming from the westerly wind rose (NW, $\mathrm{W}$, and SW), water movement from the cutoff toward the beach was relatively rapid; thus contaminated water could potentially be transported from the cutoff to the beach rapidly enough to result in contamination of the beach. In a year when CSO overflows occur more frequently, the Clinton River cutoff could be a more important source of bacterial contamination in the beach area than it was in 1998. Measurements of water movements and bacterial distribution patterns during a year with more frequent CSO overflows will be necessary to determine whether transport of contaminated water from the cutoff actually results in significant contamination of the beach. 


\section{References}

Barko, J. W., D. J. Bates, G. J. Filbin, S. M. Hennington, and D. G. McFarland. (1981). Seasonal growth and community composition of phytoplankton in a eutrophic Wisconsin impoundment. Journal of Freshwater Ecology 2:519534.

Fox, A. P. (1998). Meteorolgical analysis of the Lake St. Clair Region, as it pertained to the aquatic plant episode of 1994. M.S. Thesis, Eastern Michigan University, Ypsilanti, MI.

Golden Software. (1997). SURFER FOR WINDOWS, User's Guide. Version 6. Golden Software, Inc., Golden, CO.

U.S. Army Corps of Engineers. (1996). "Lake St. Clair, Michigan aquatic plant management investigation,” U.S. Army Engineer District, Detroit, Detroit, MI. 


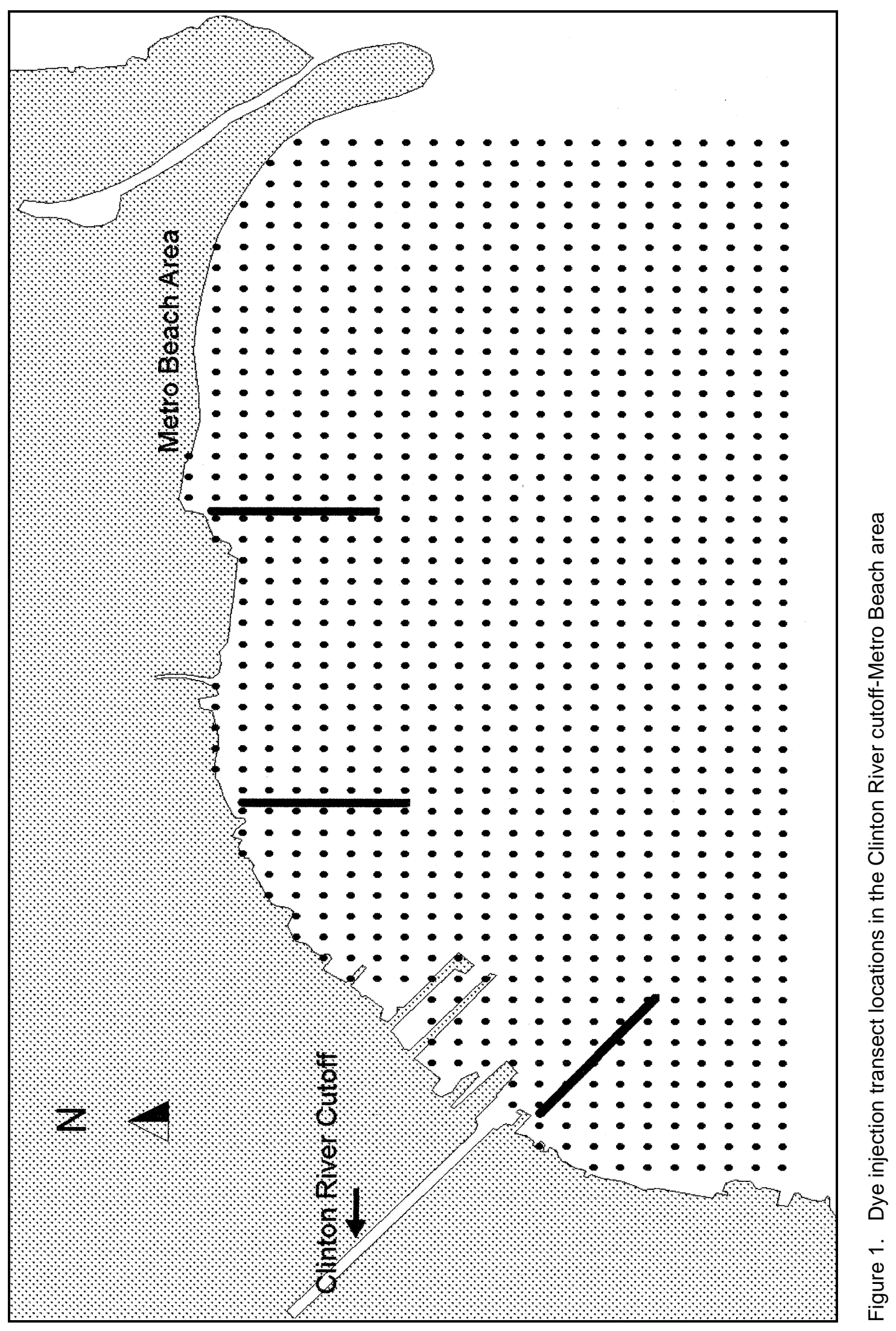




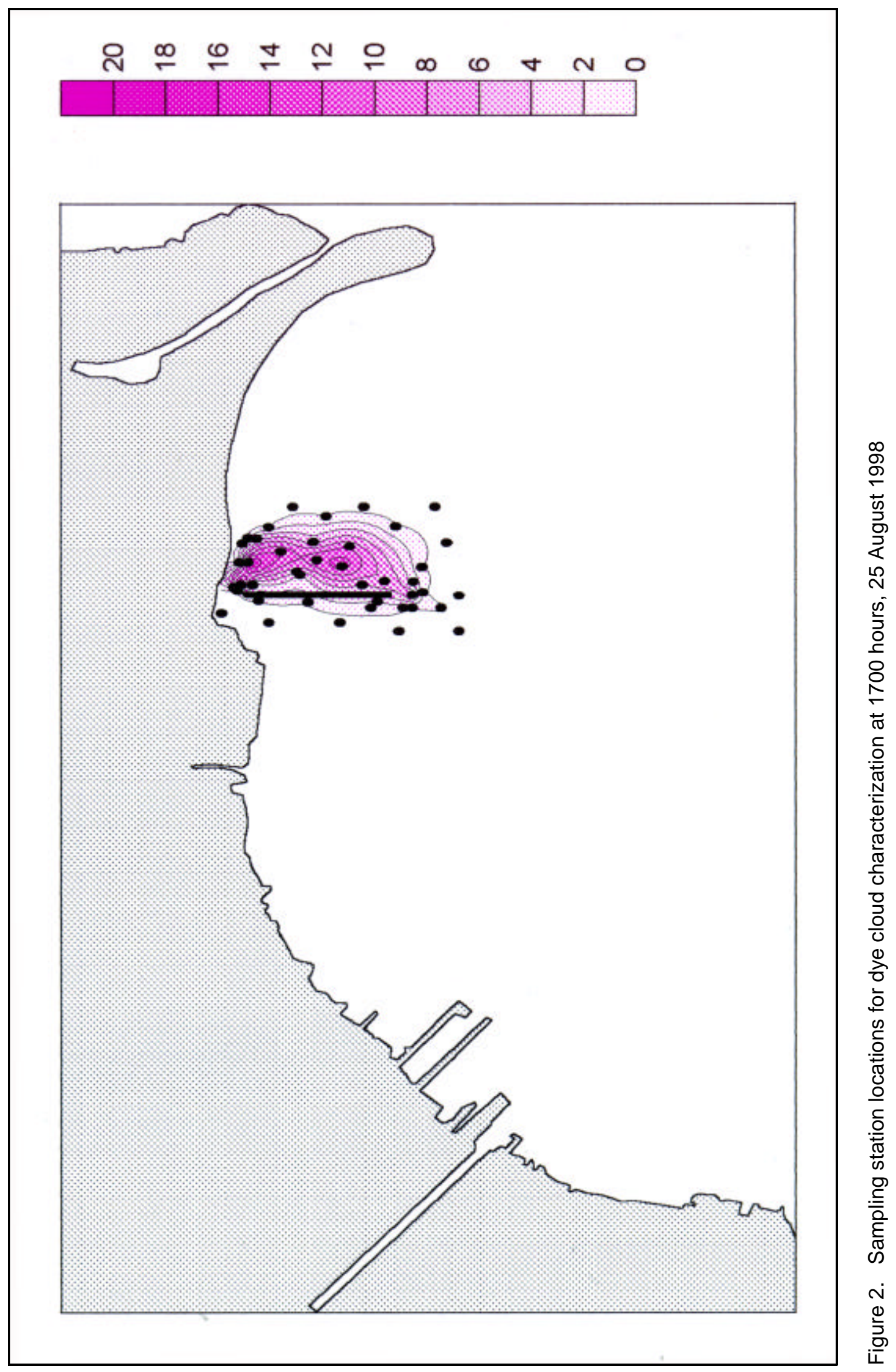




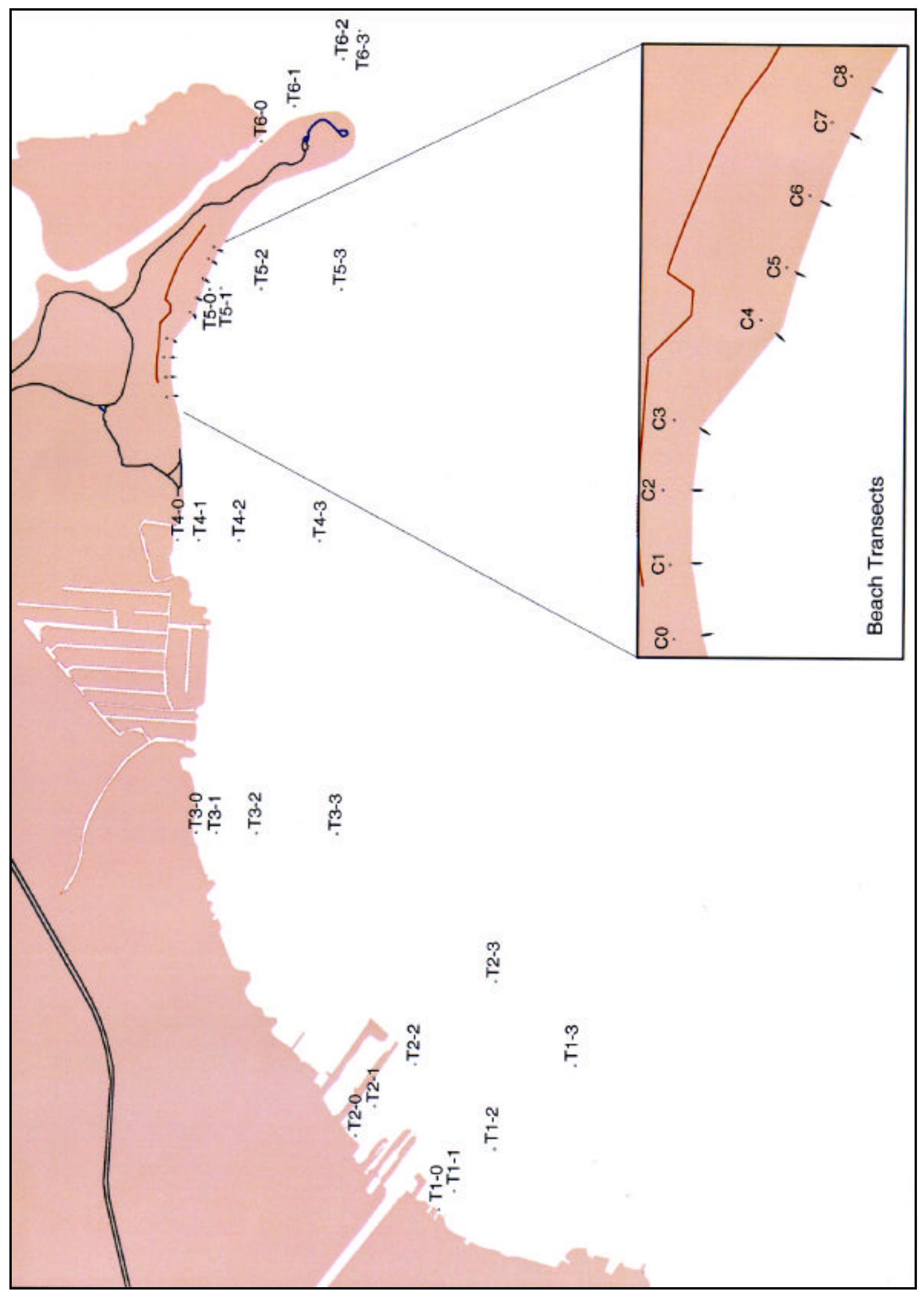

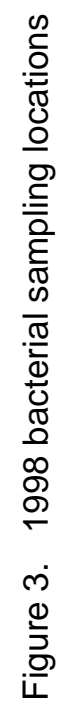




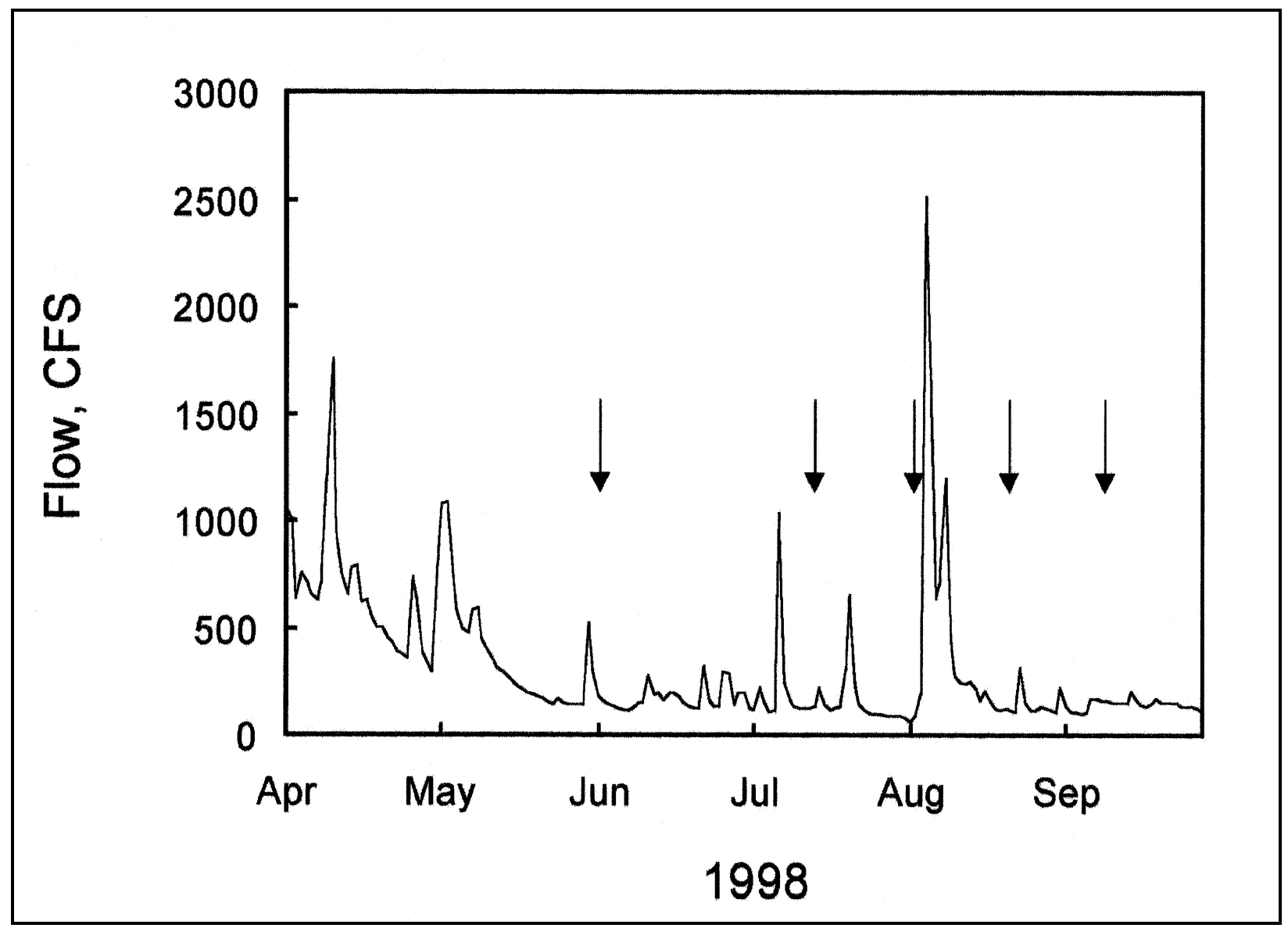

Figure 4. Mean daily flow for the Clinton River near Fraser, MI, for the summer period, 1998. Arrows denote study periods for examination of water movement near the Clinton River cutoff-Metro Beach area of Lake St. Clair 


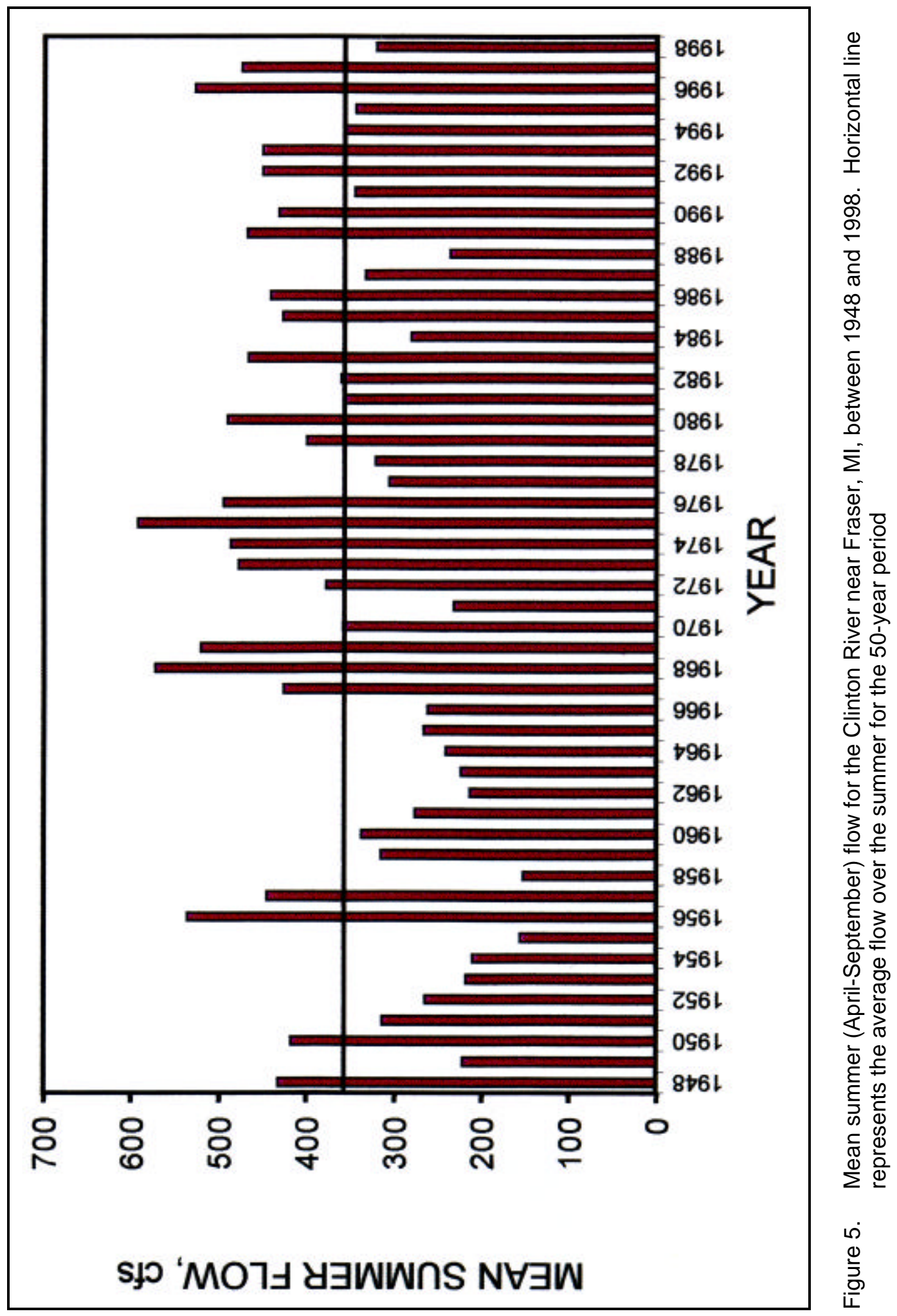




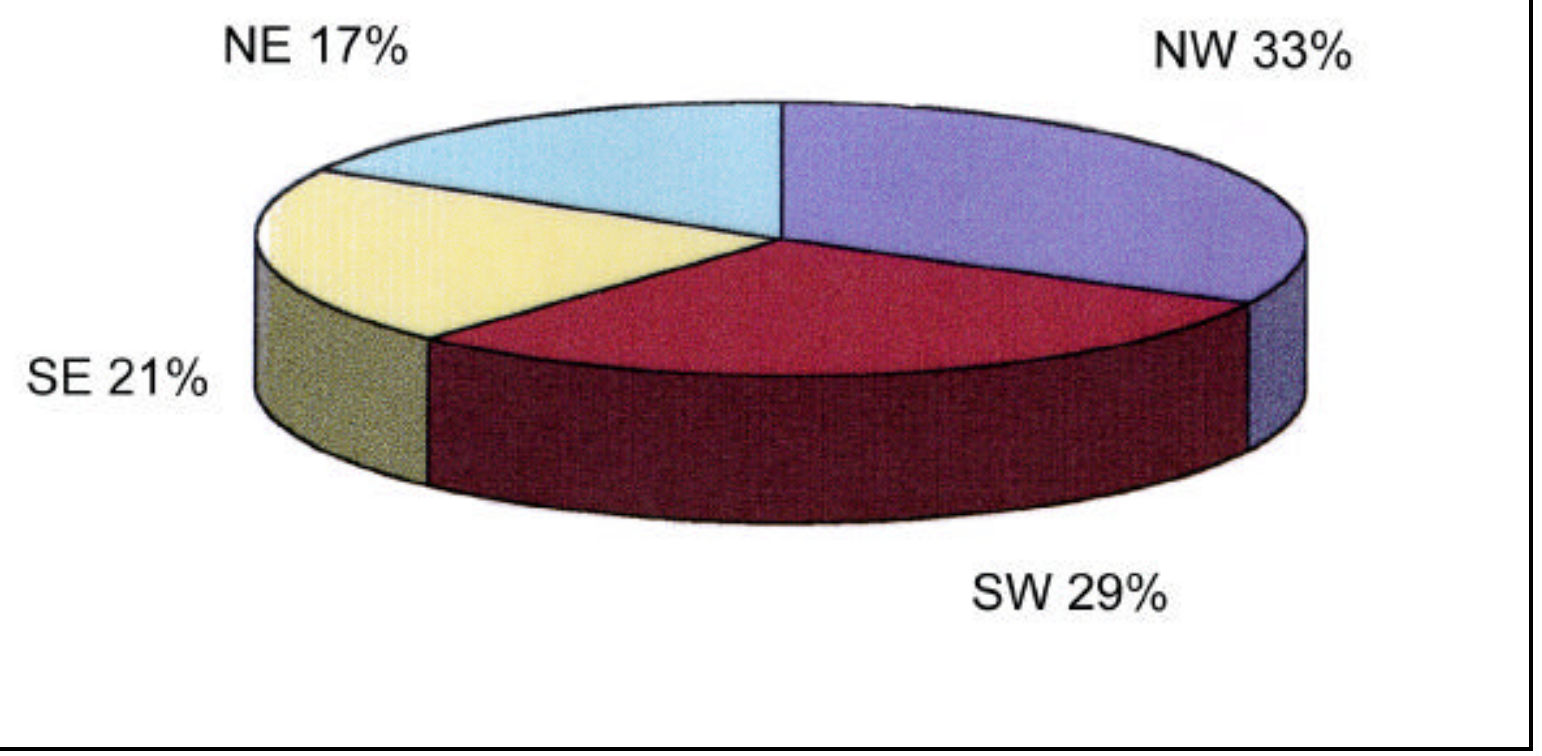

Figure 6. Wind direction relative percent during the summer of 1998 


\section{ヨSOy ONIM}

专需㟧崖
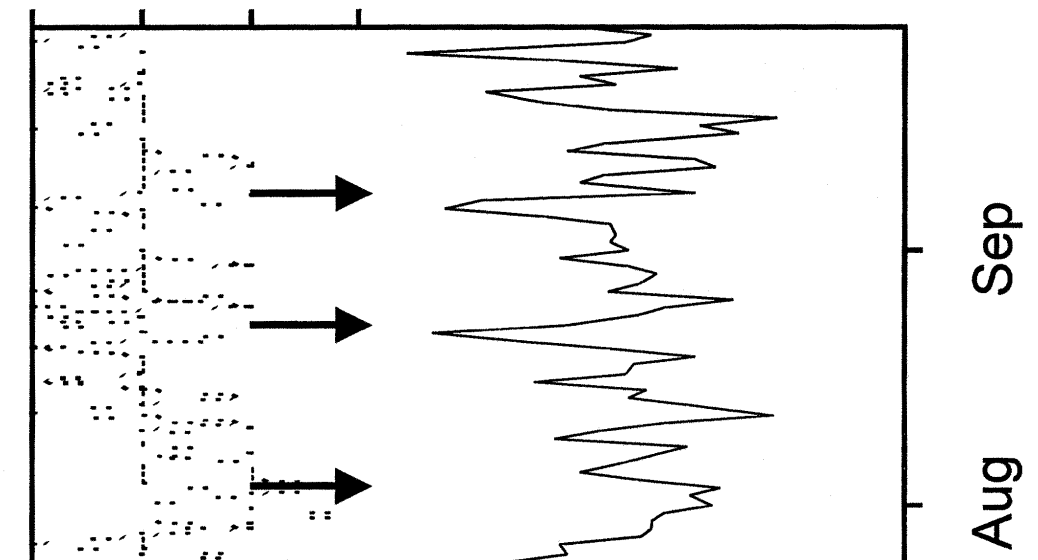

$\frac{0}{1}$

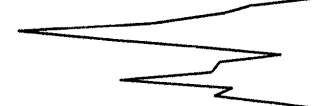

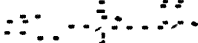
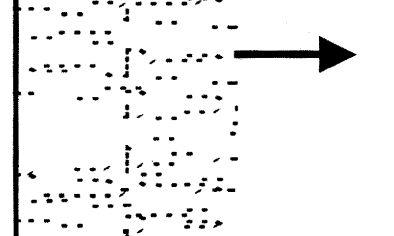

…

$\because: 3$

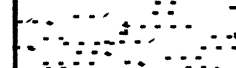
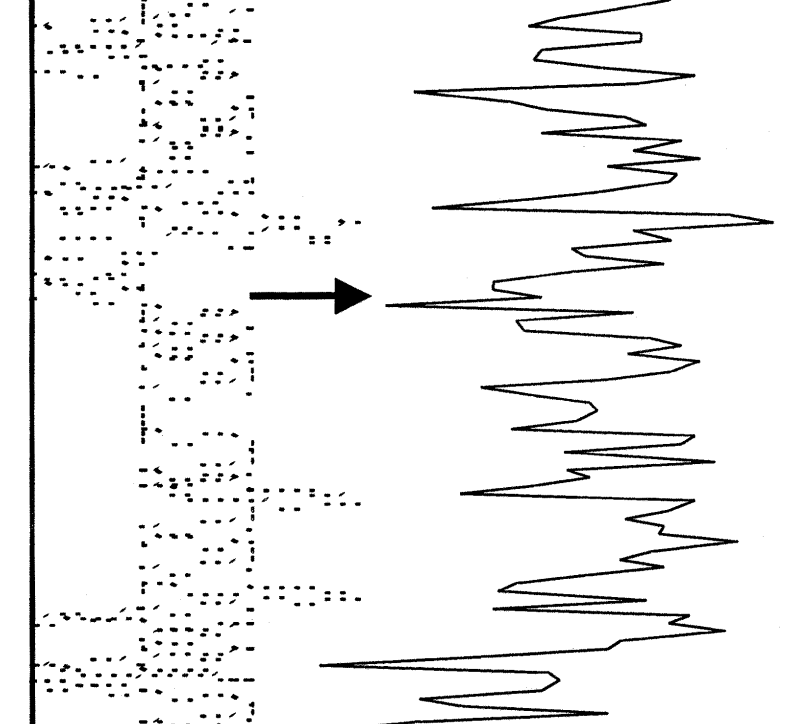

$\because \ldots$

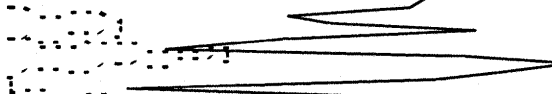

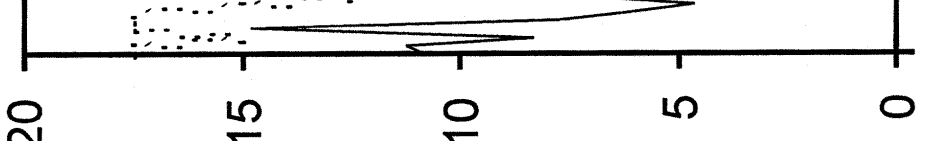

훈

$\bar{i} \stackrel{\infty}{\infty}$

웆

ळ

ब

ธั ส

ঠั

ह 들

का

$\risingdotseq$

인

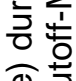

ฮิ

이

幽:

蛋

으월

必

임

등

3

त्ञ

तु

또을

¿

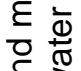

สิ 3

(1)

드 등 을

응 옹

ज़ $\frac{0}{0}$

రृ

क은

든 응

ㅊํㅇ

중

들 혼

ฮ

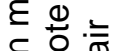

$\therefore \frac{\pi}{0}$

ट

을

离造离

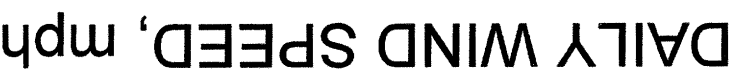

손 


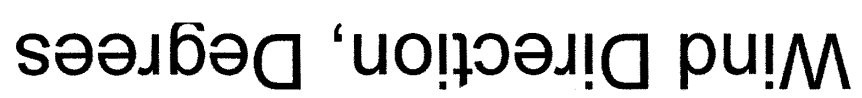

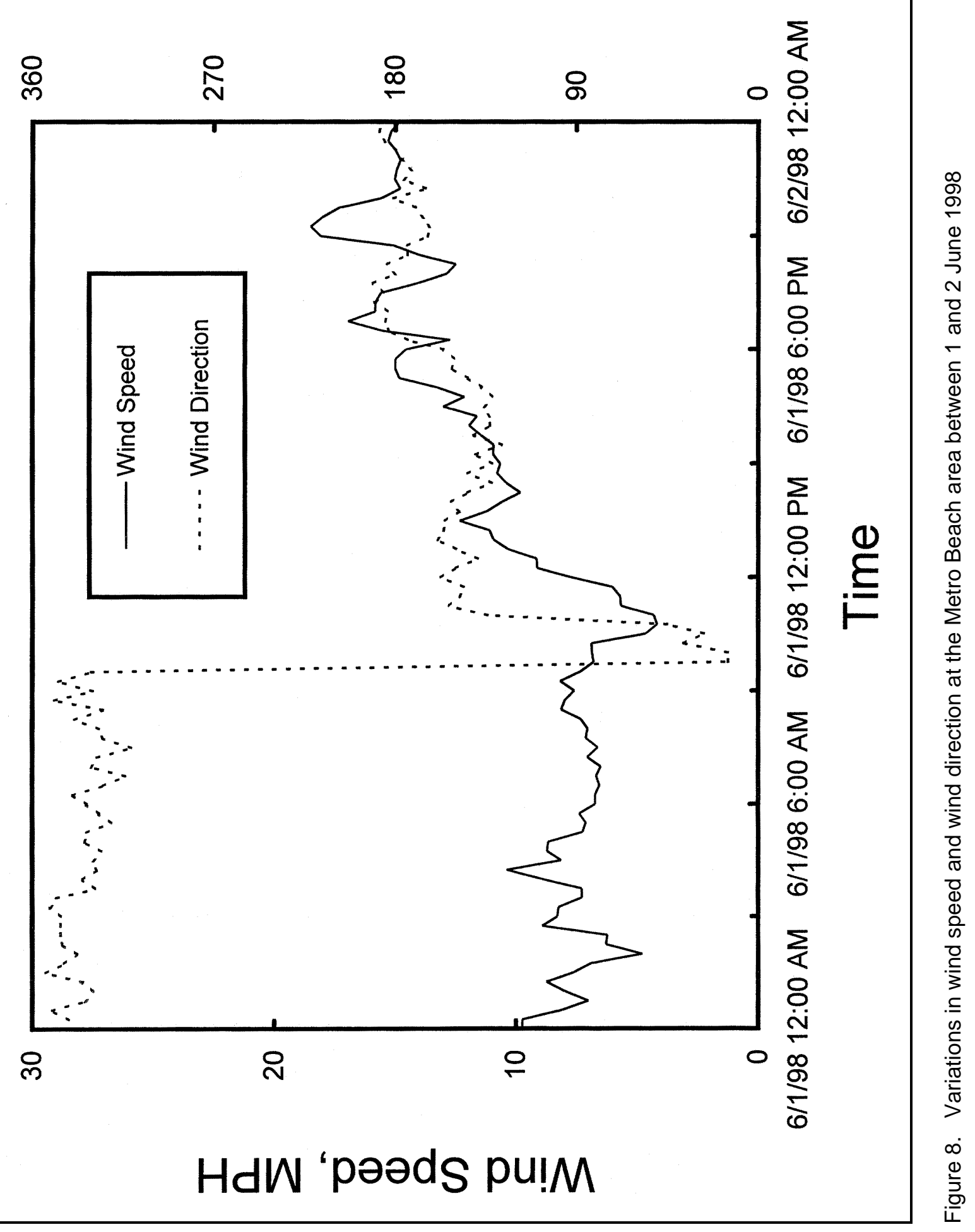




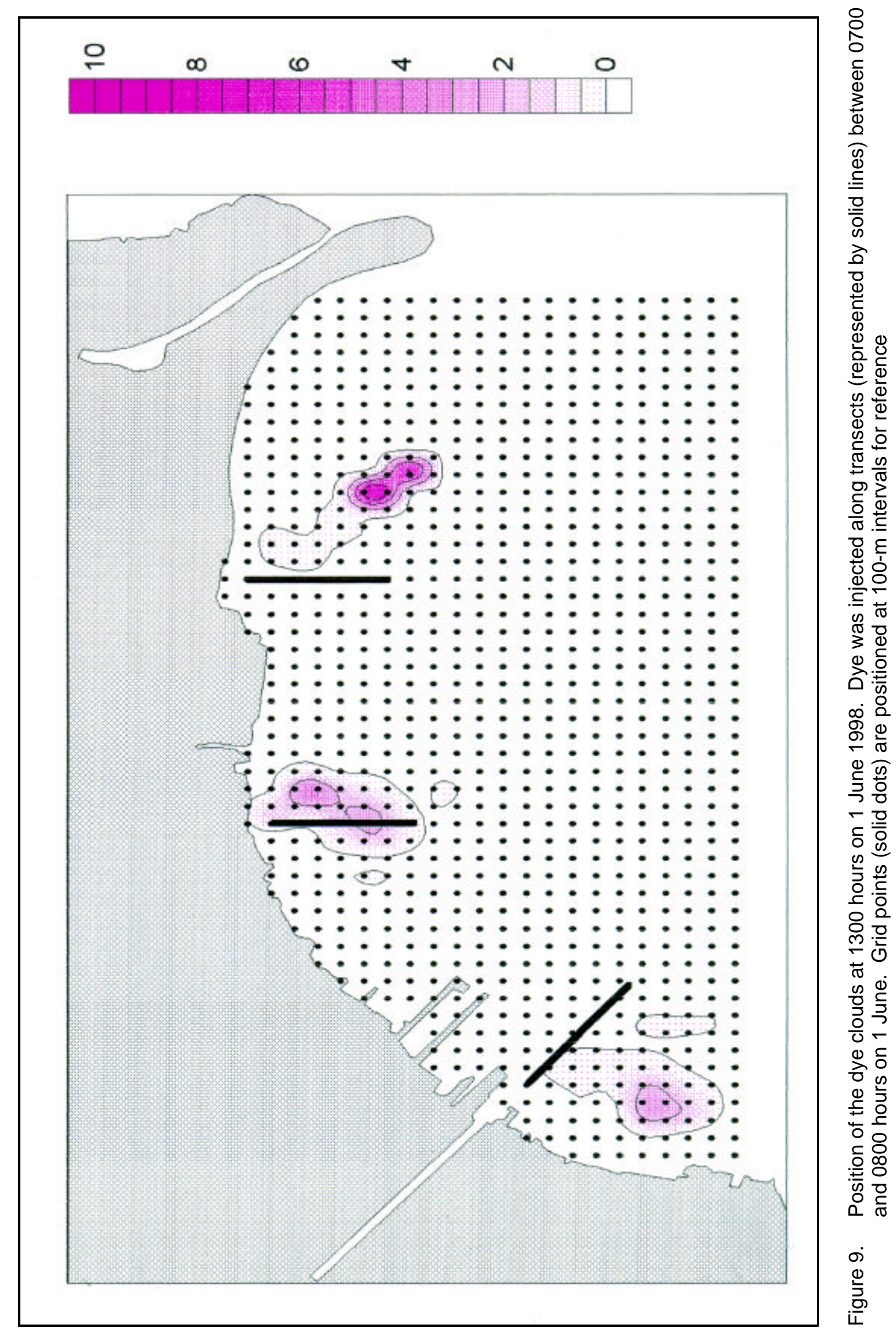




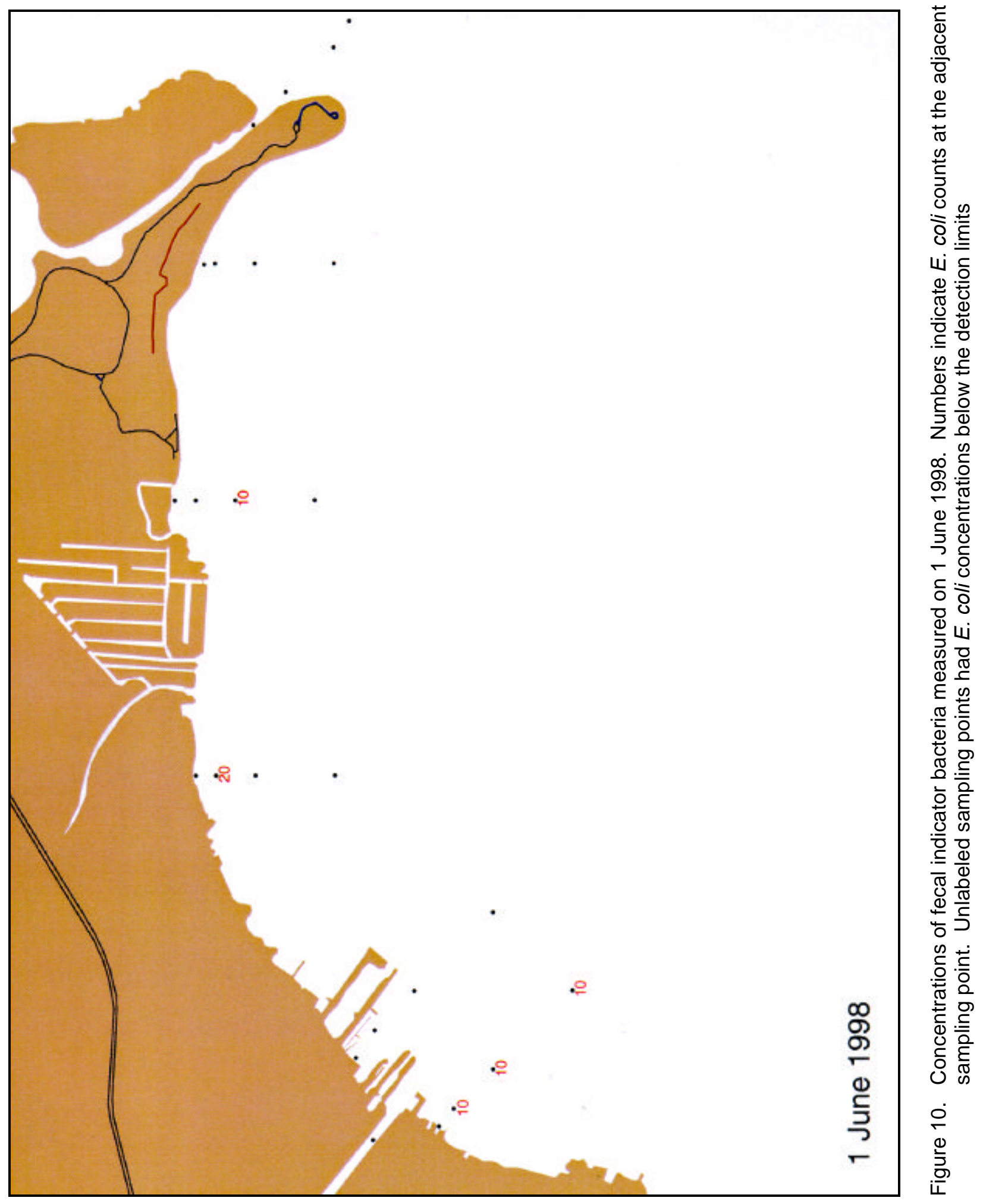




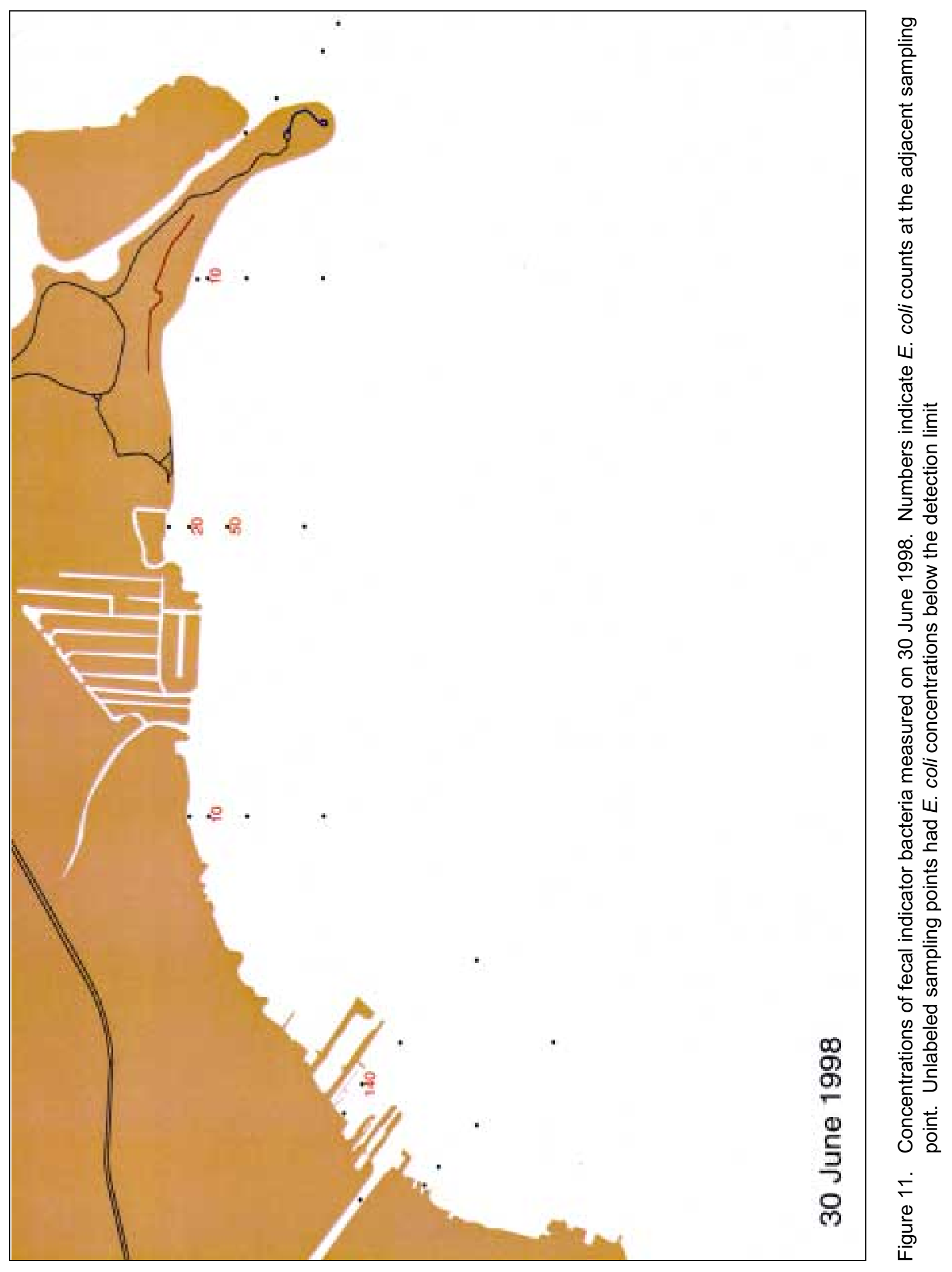




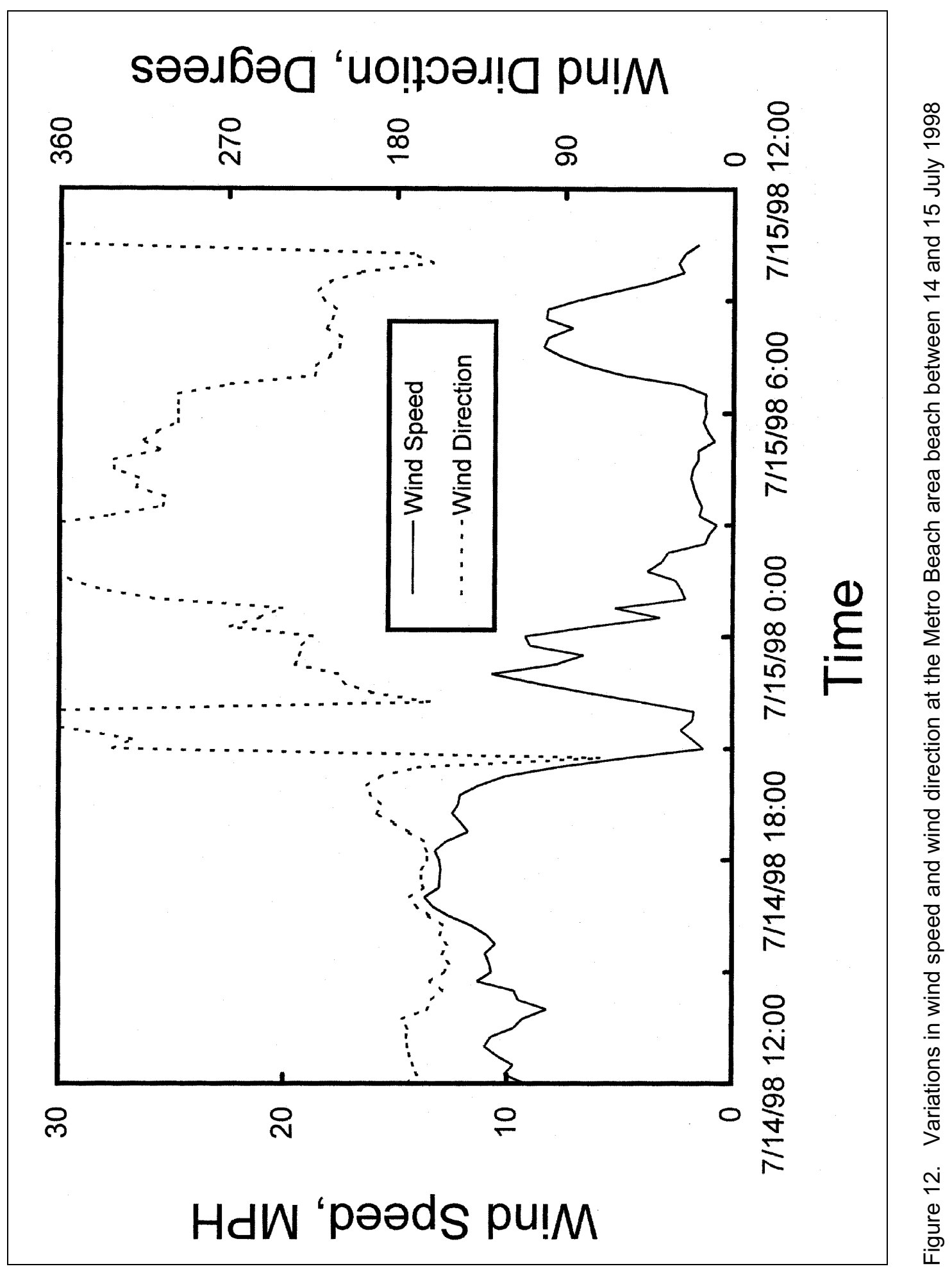




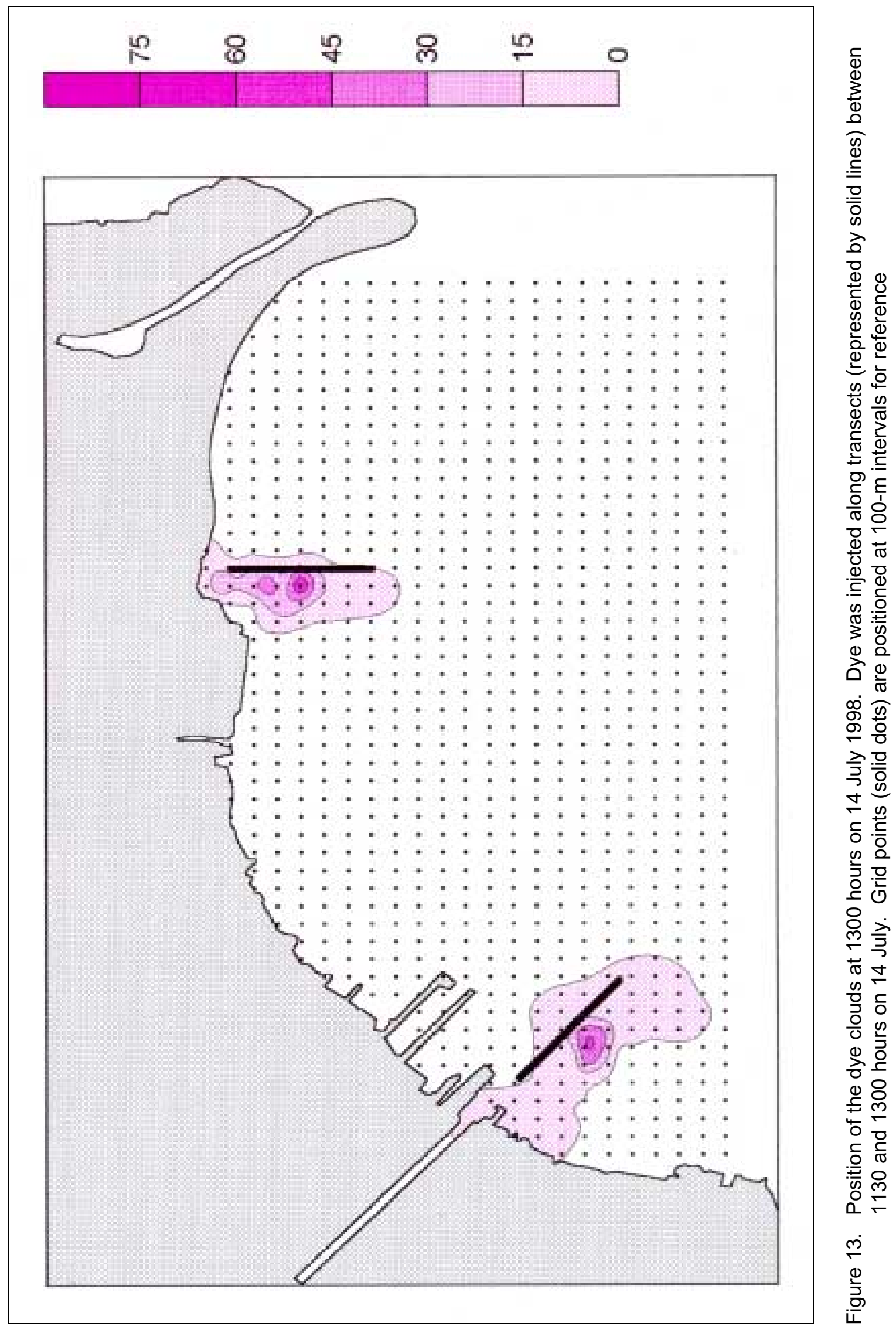




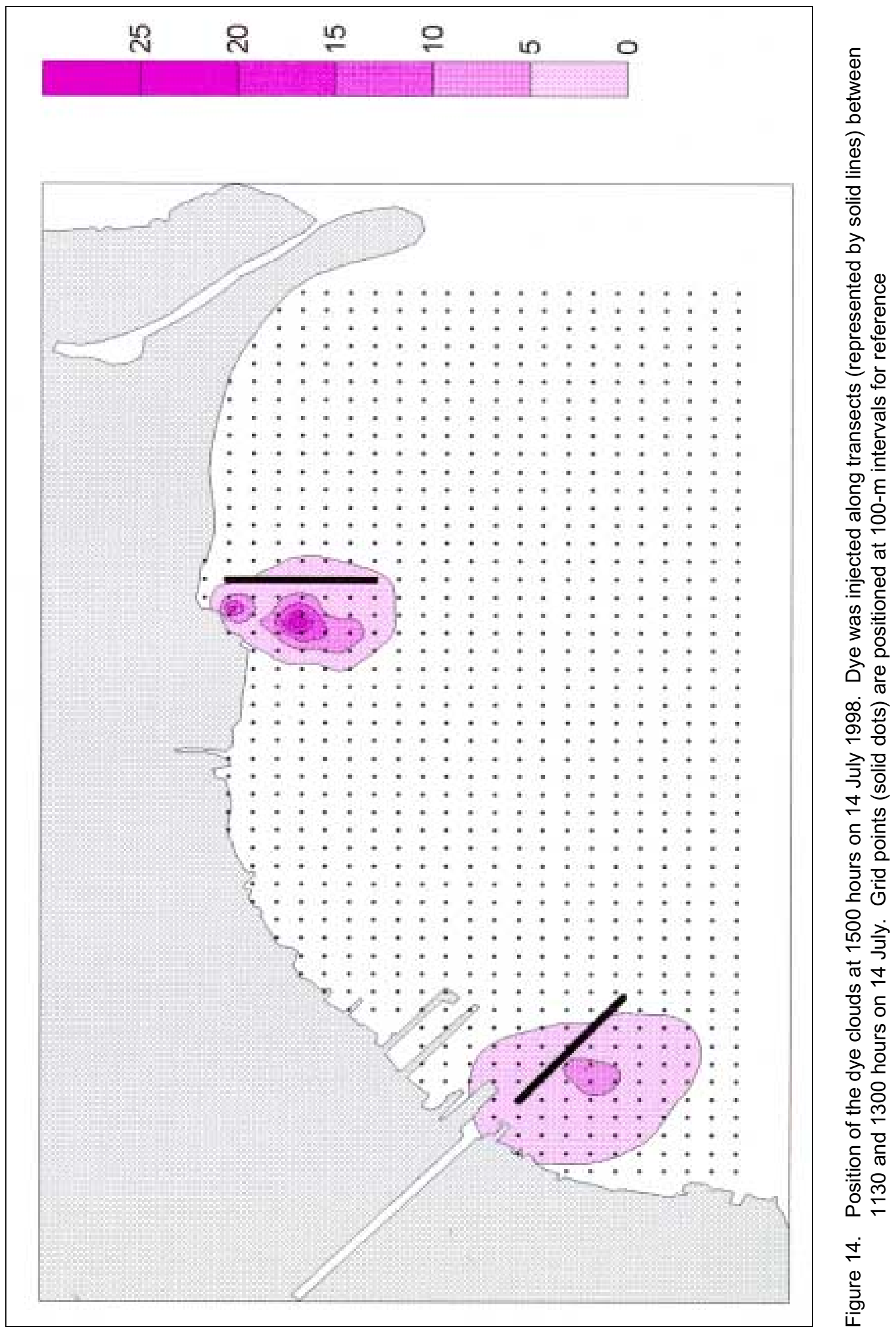




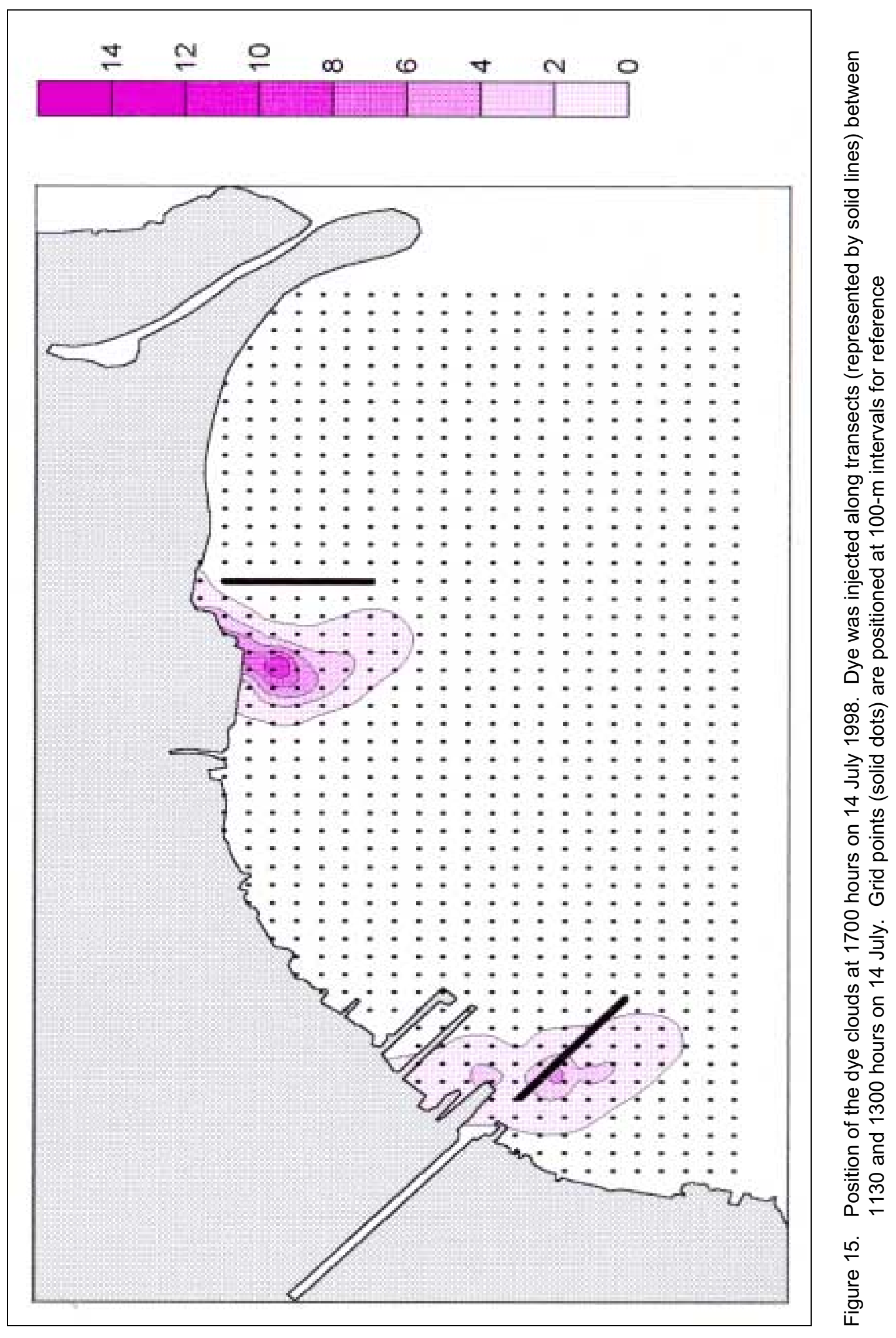




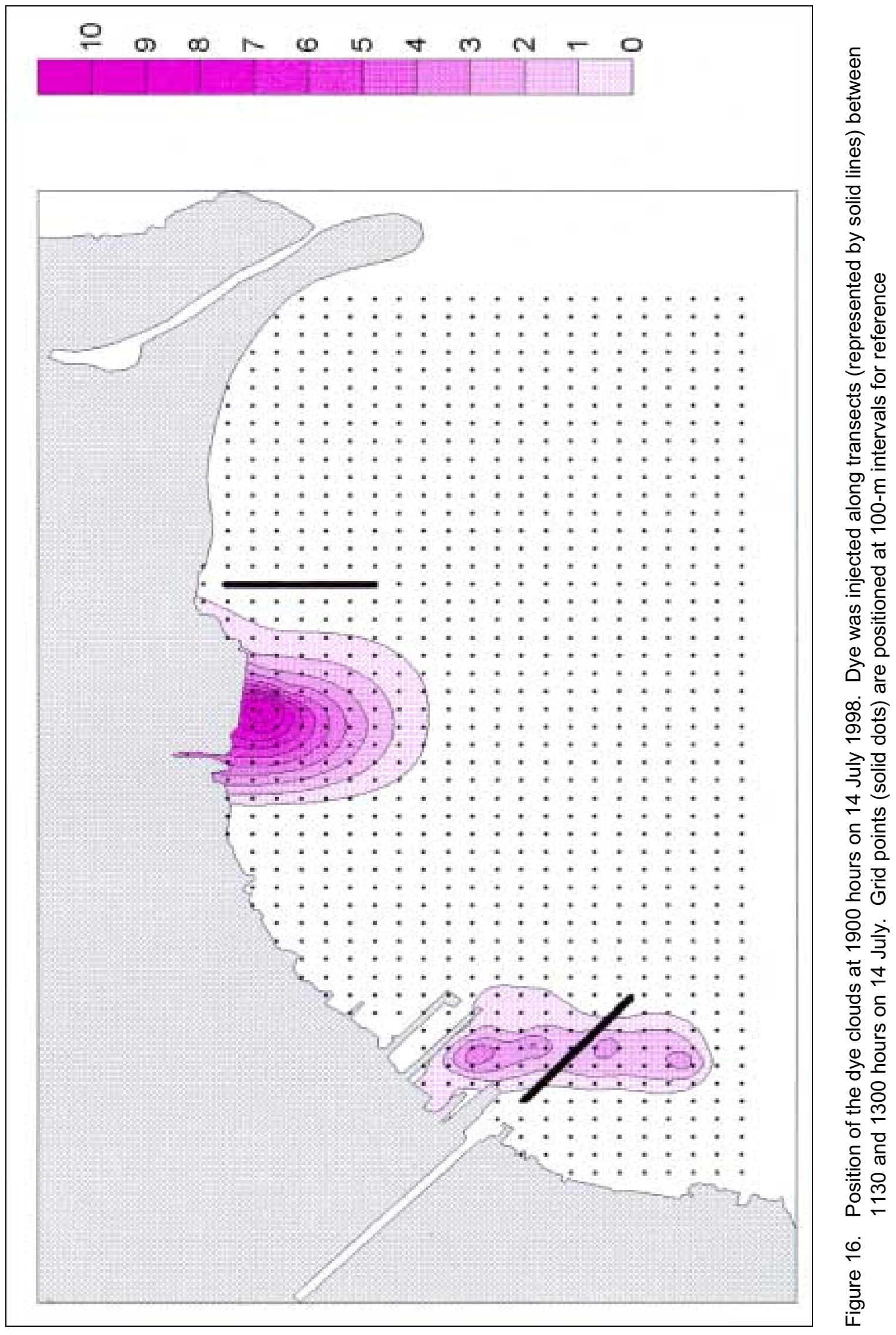




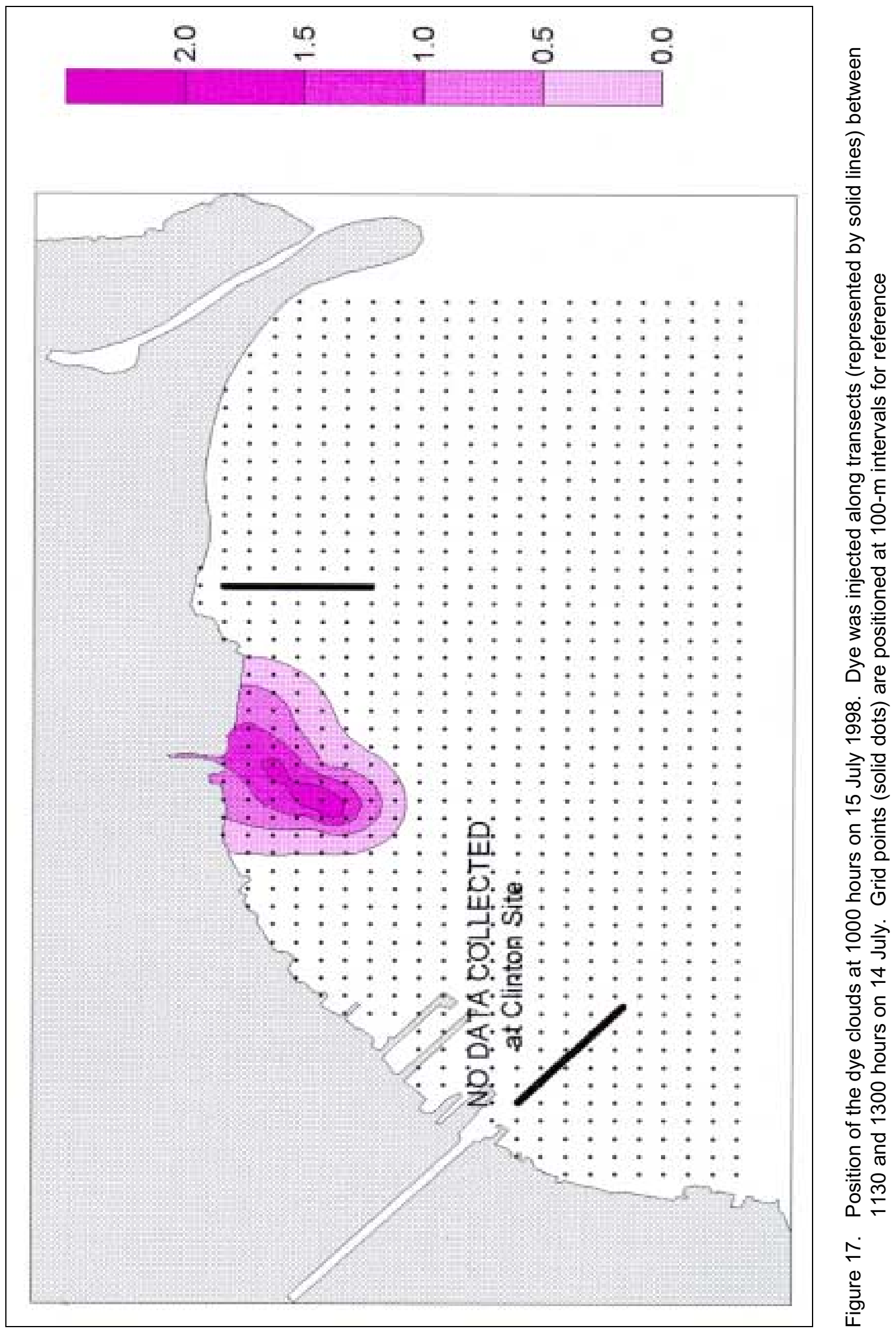




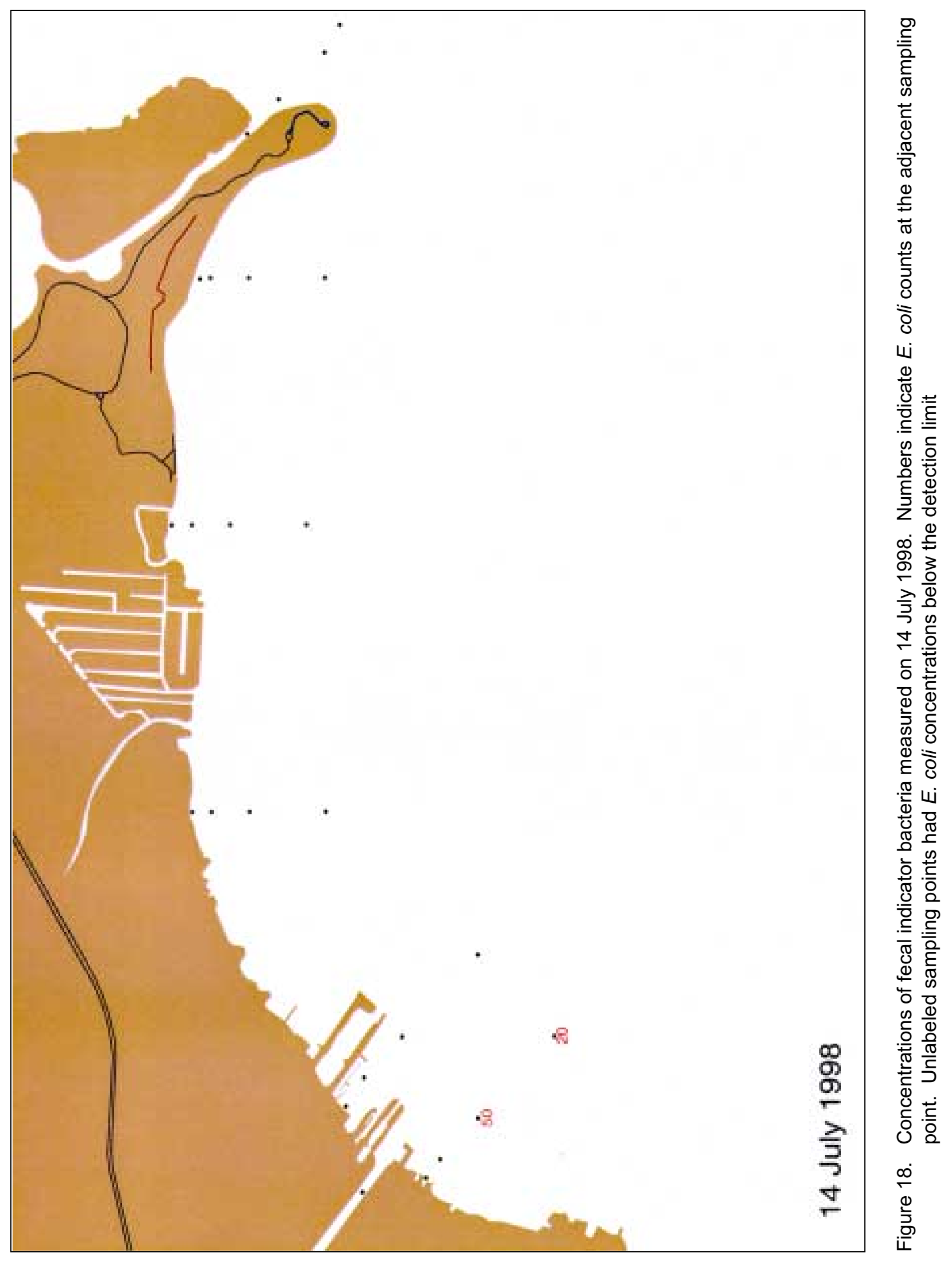




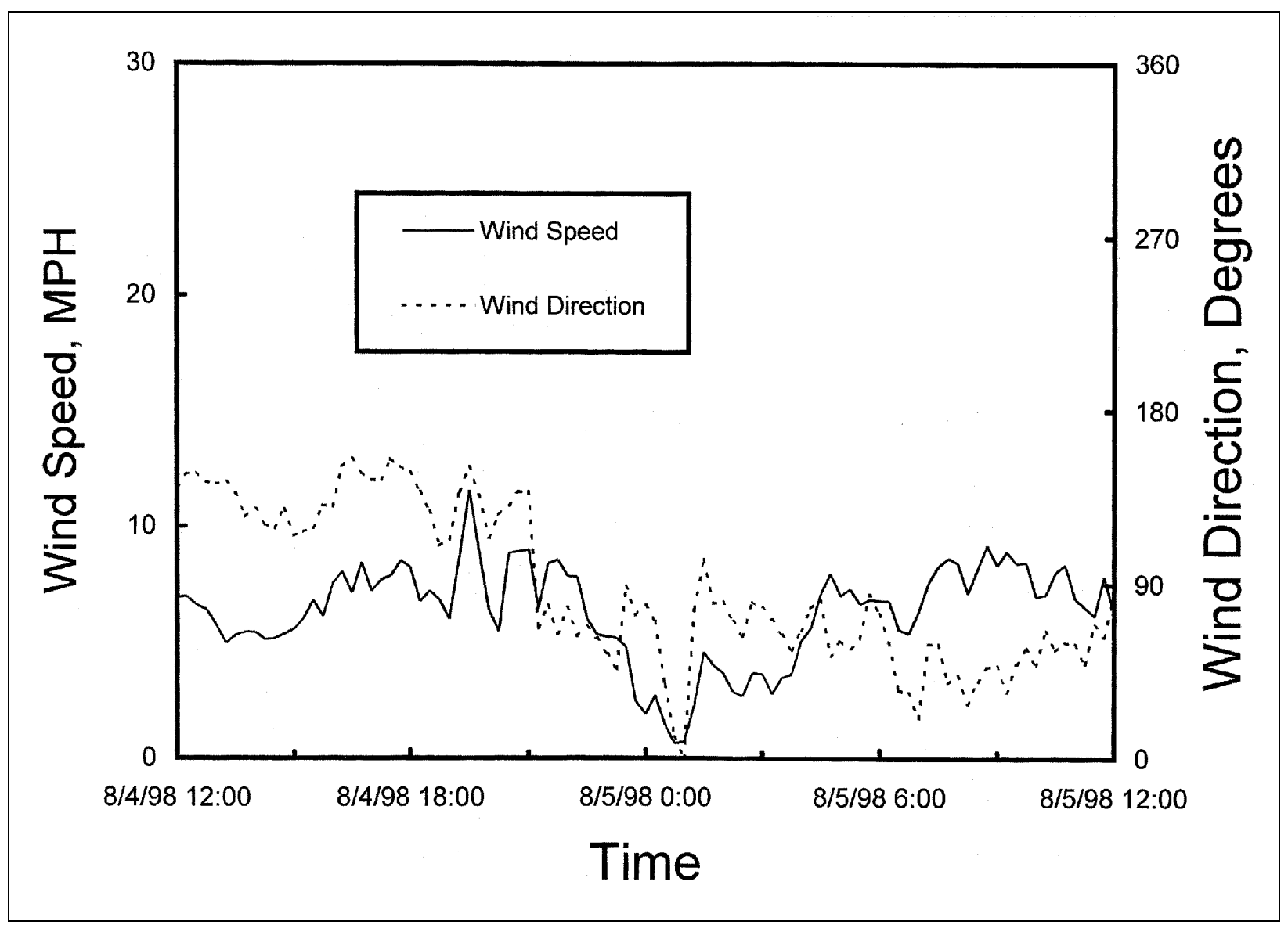

Figure 19. Variations in wind speed and wind direction at the Metro Beach area beach between 4 and 5 August 1998 


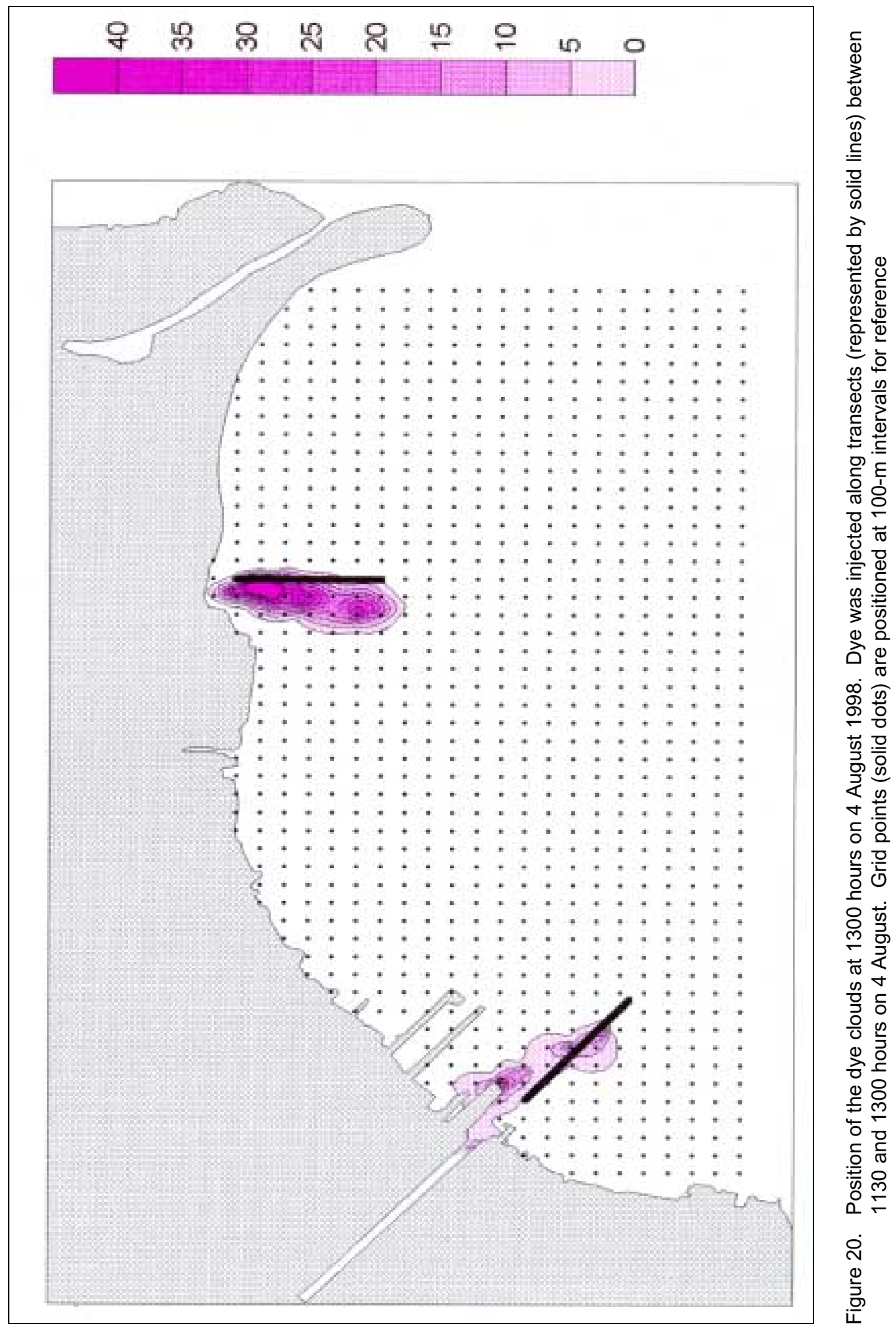




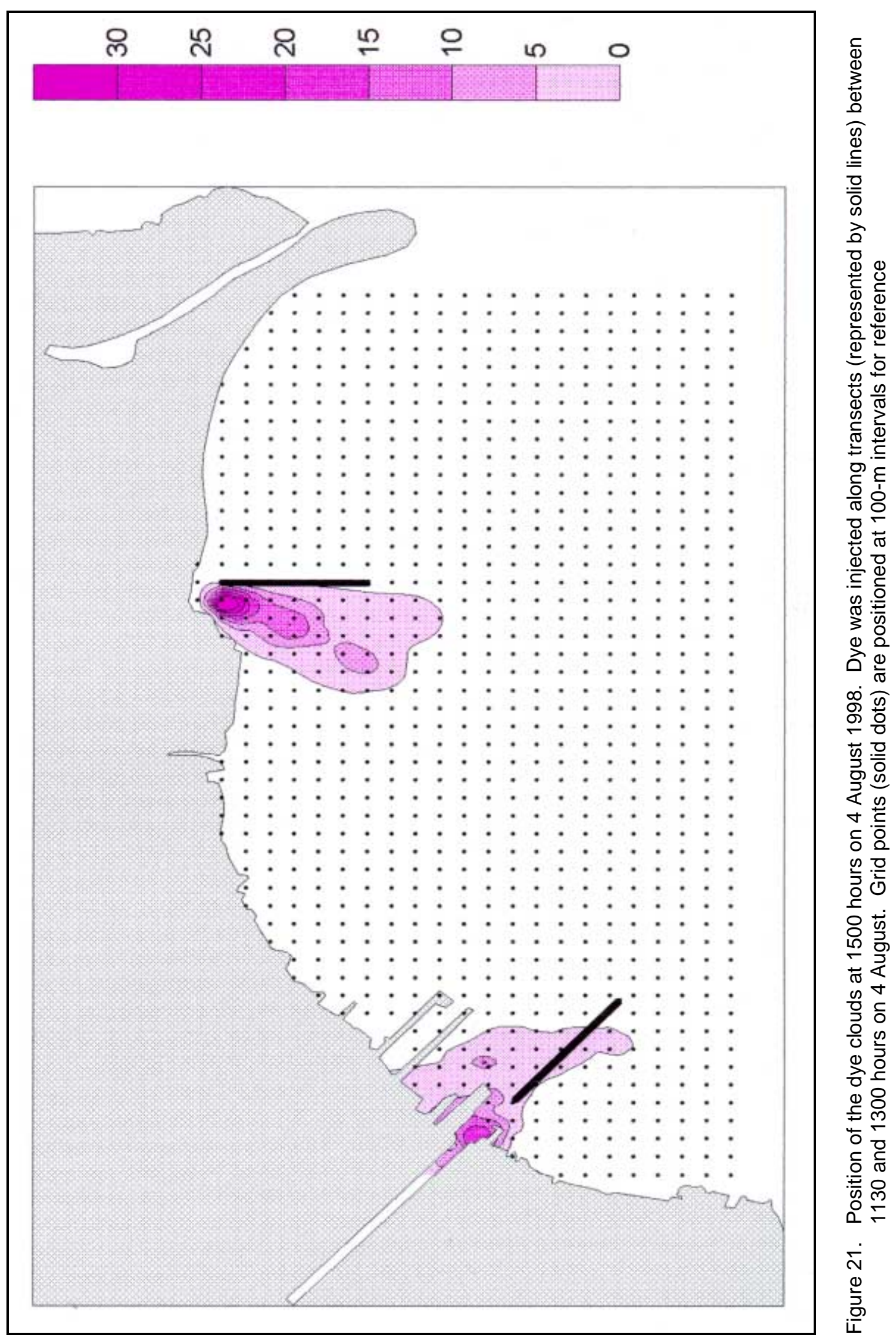




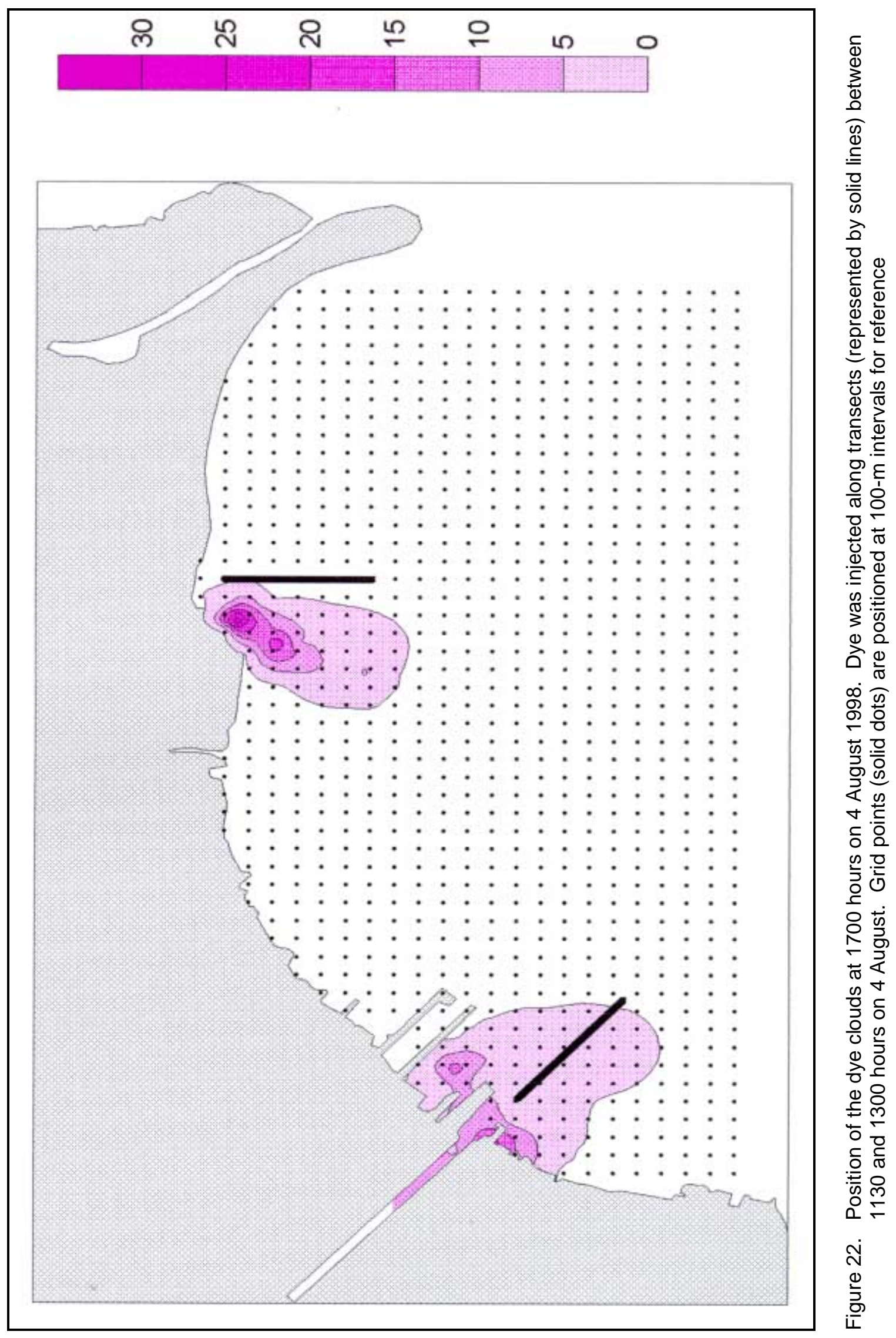




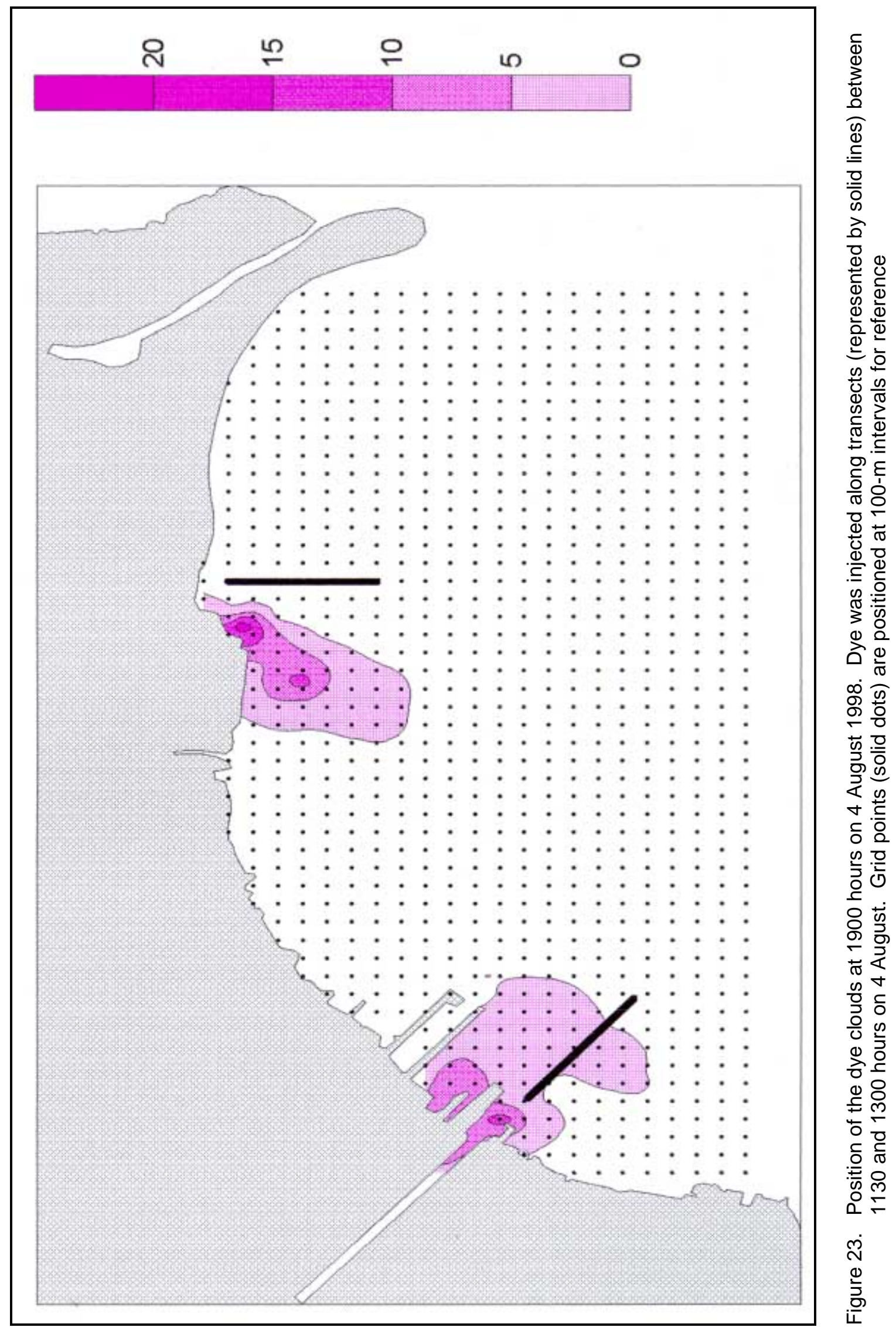




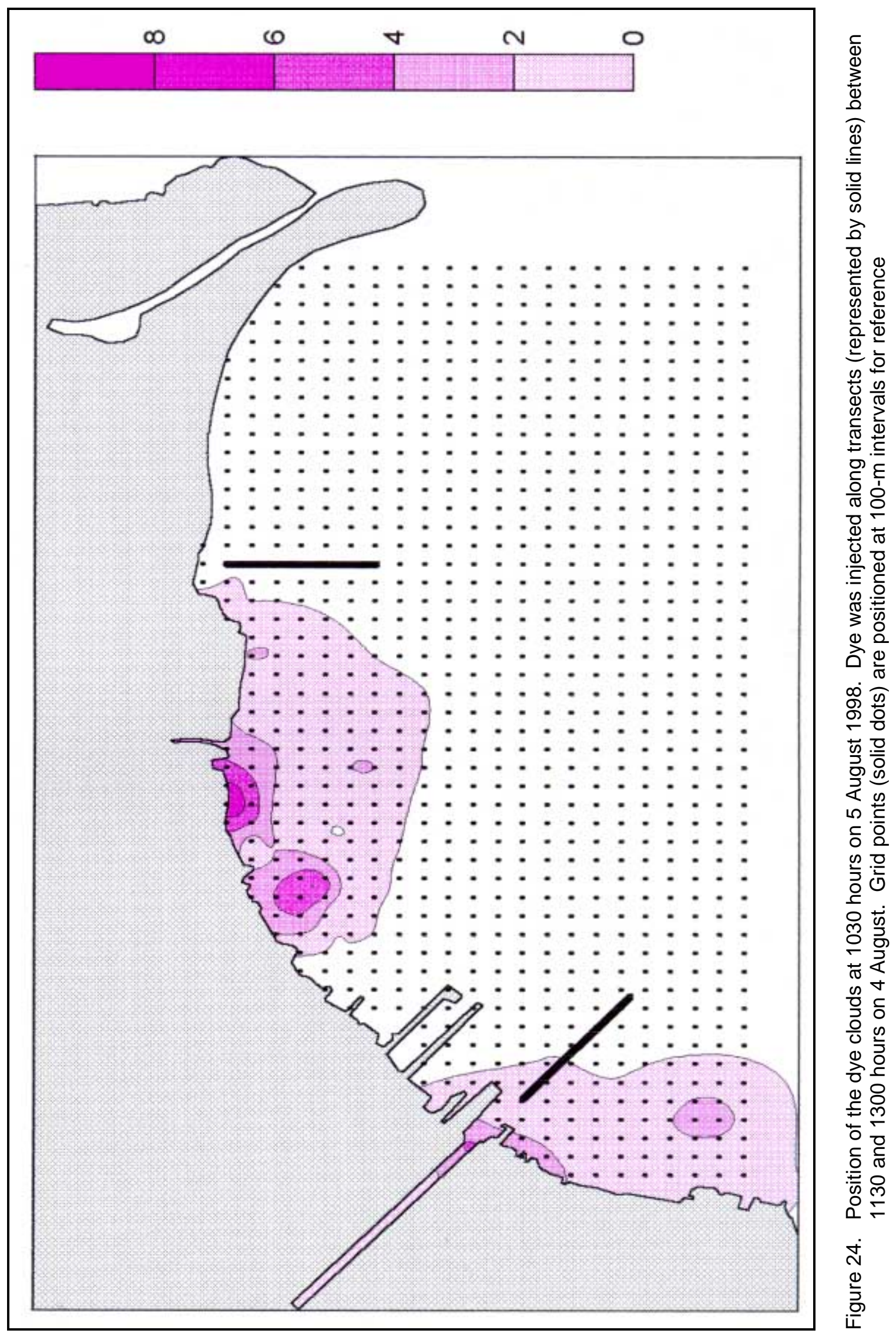




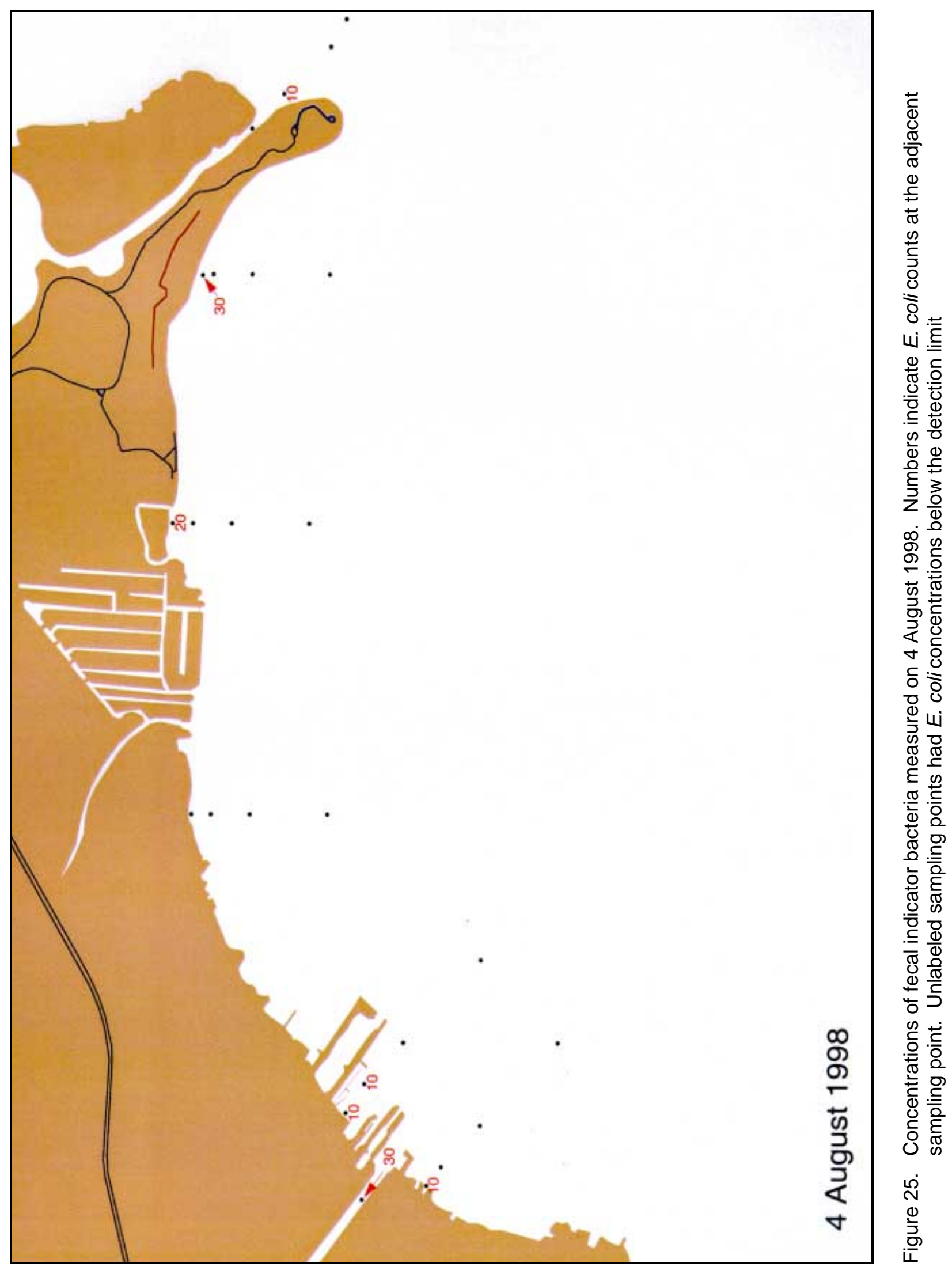




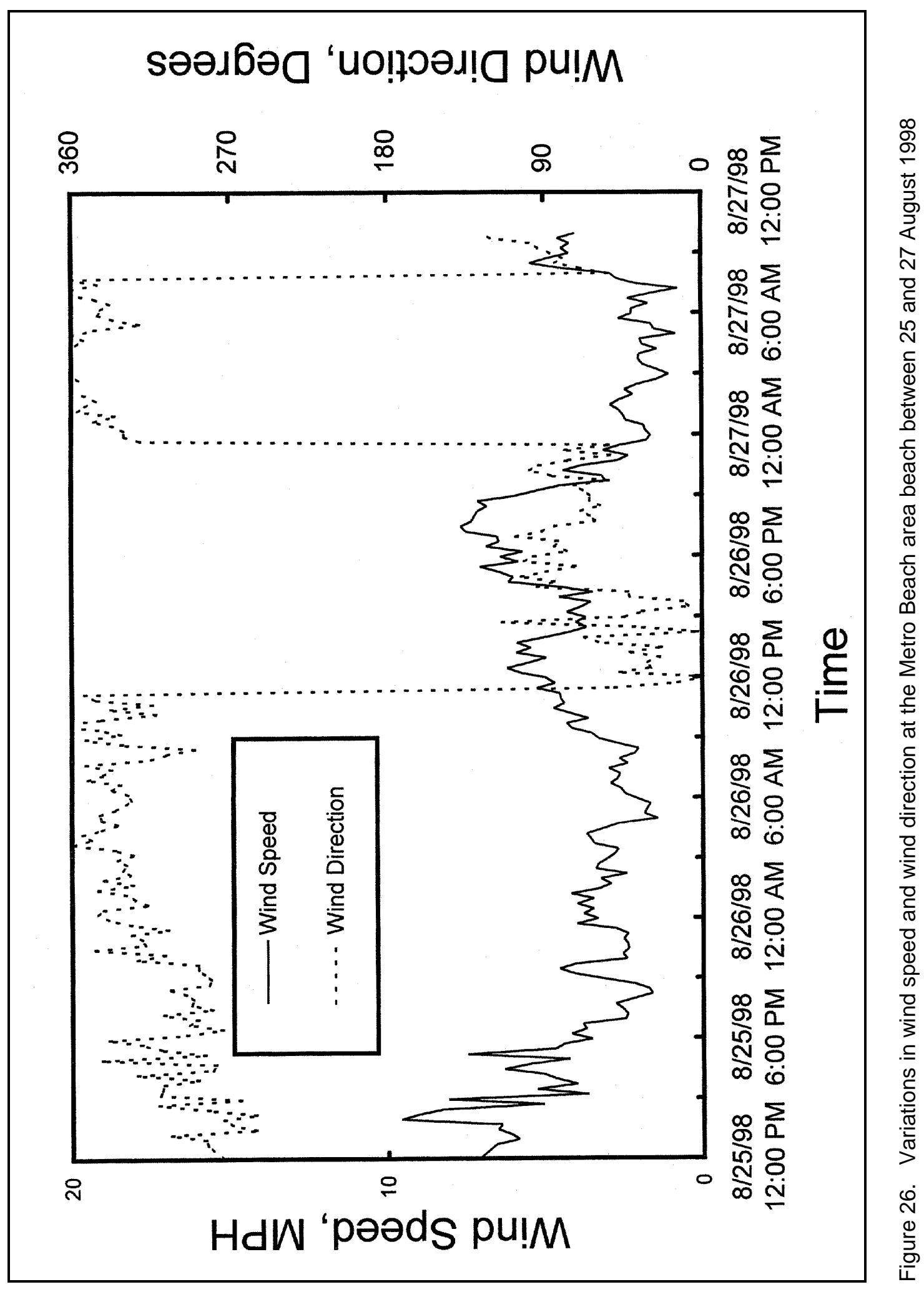




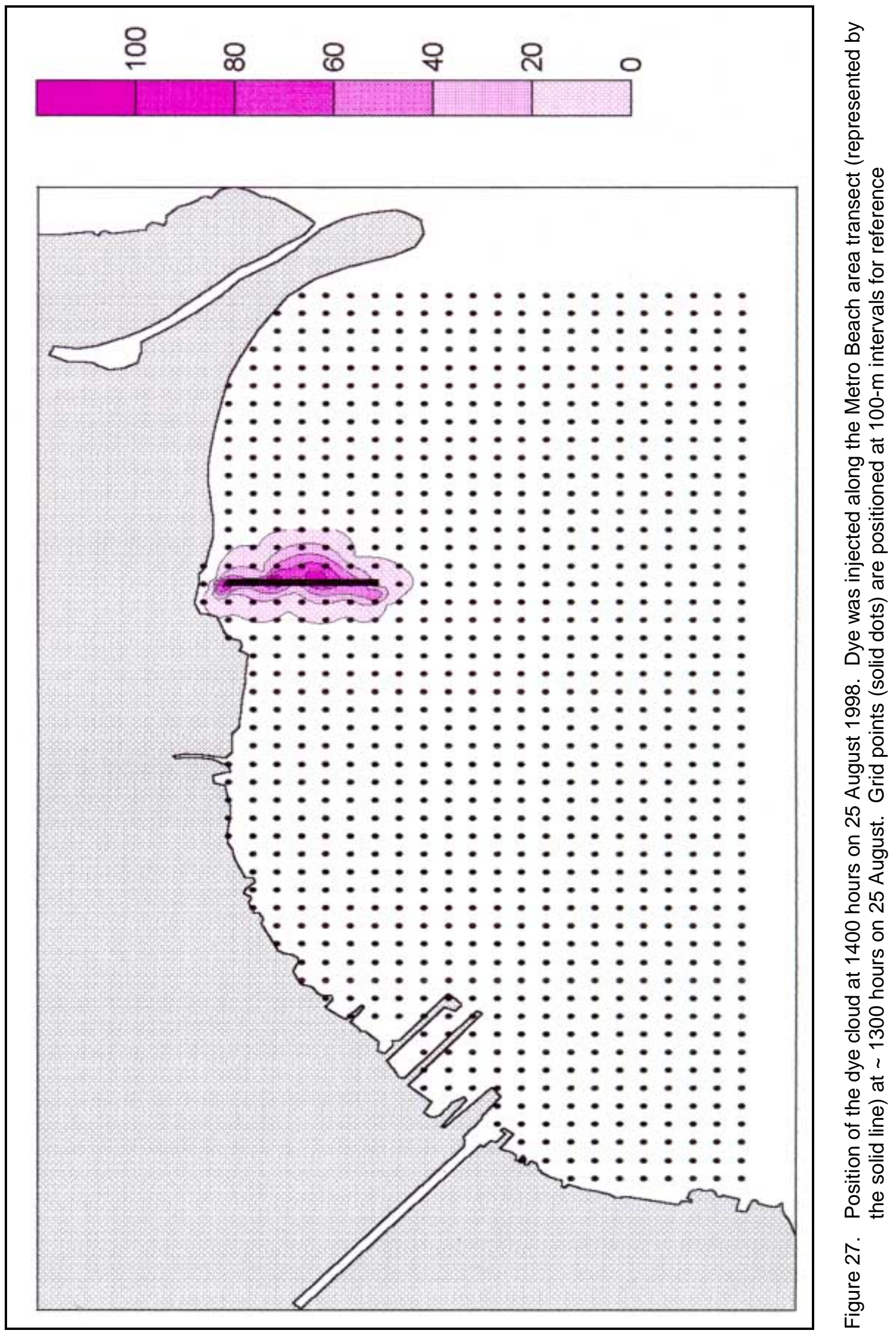




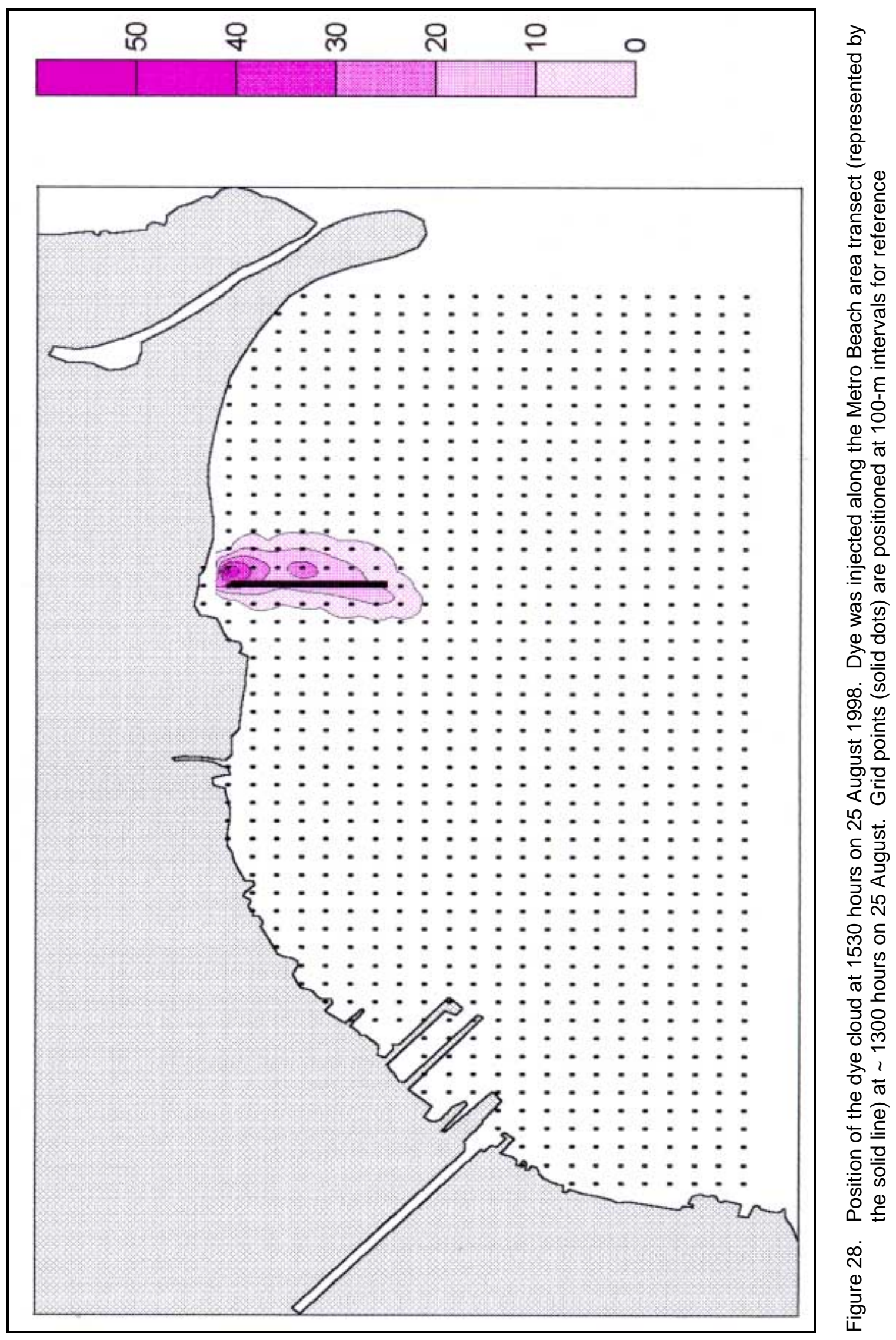




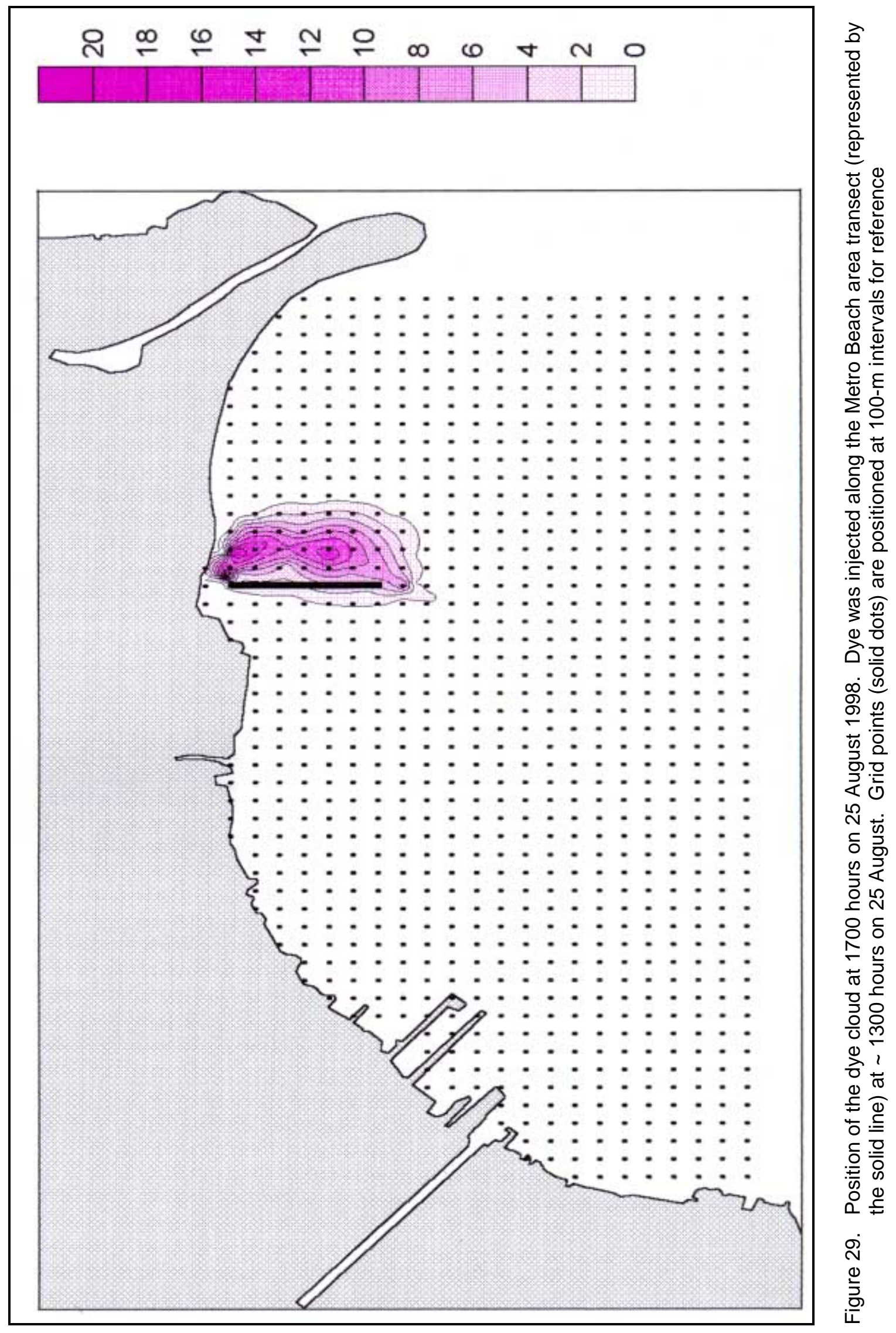




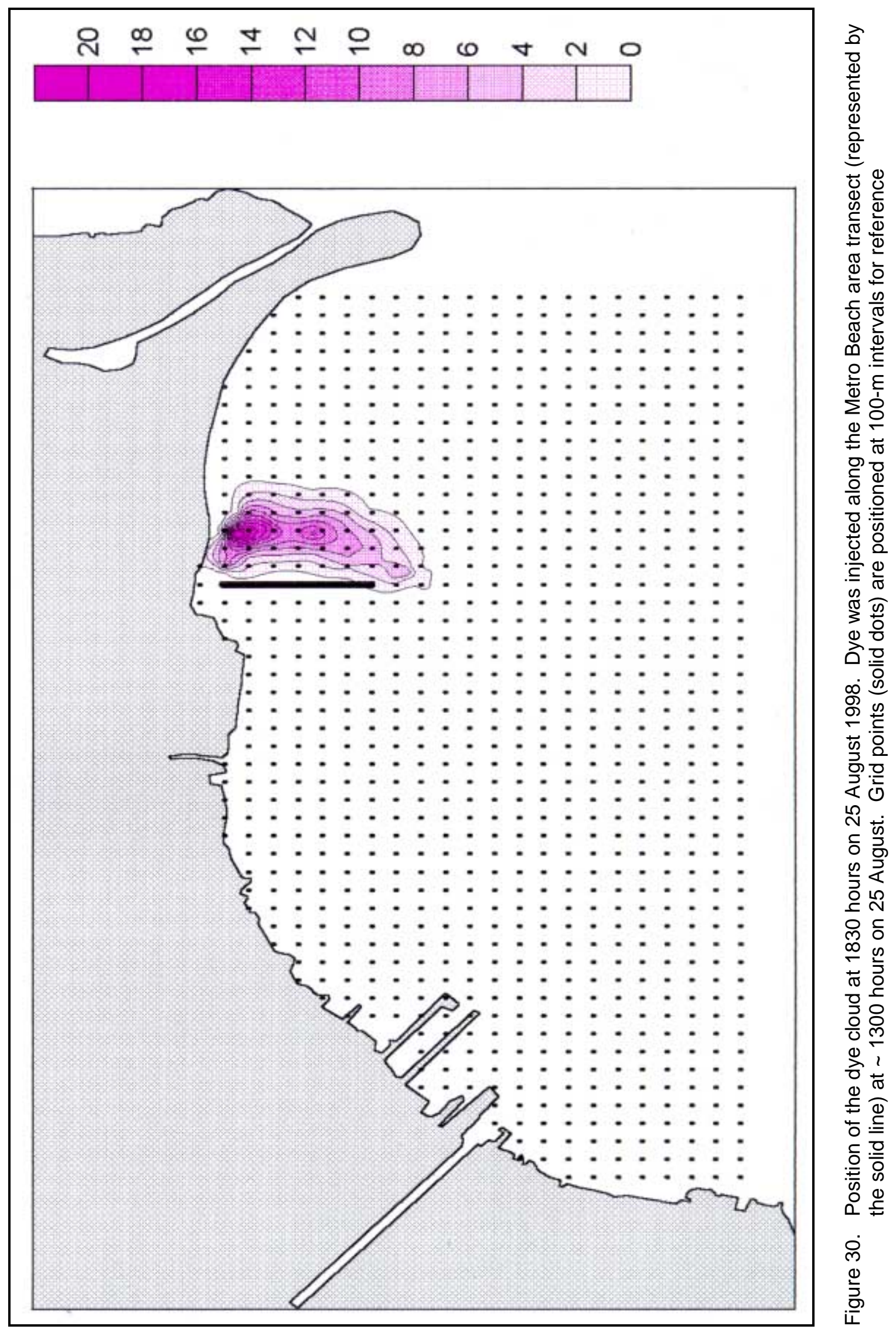




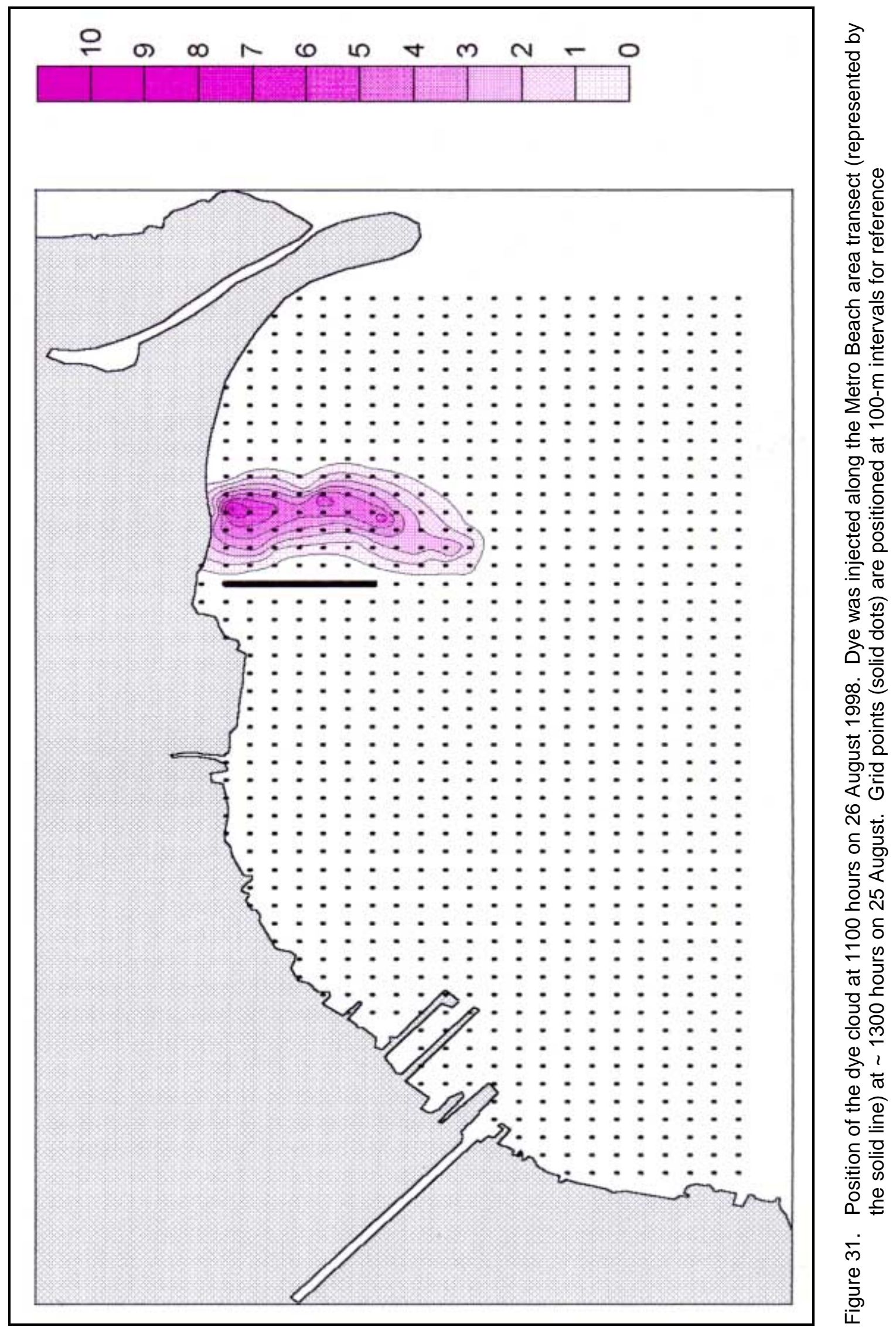




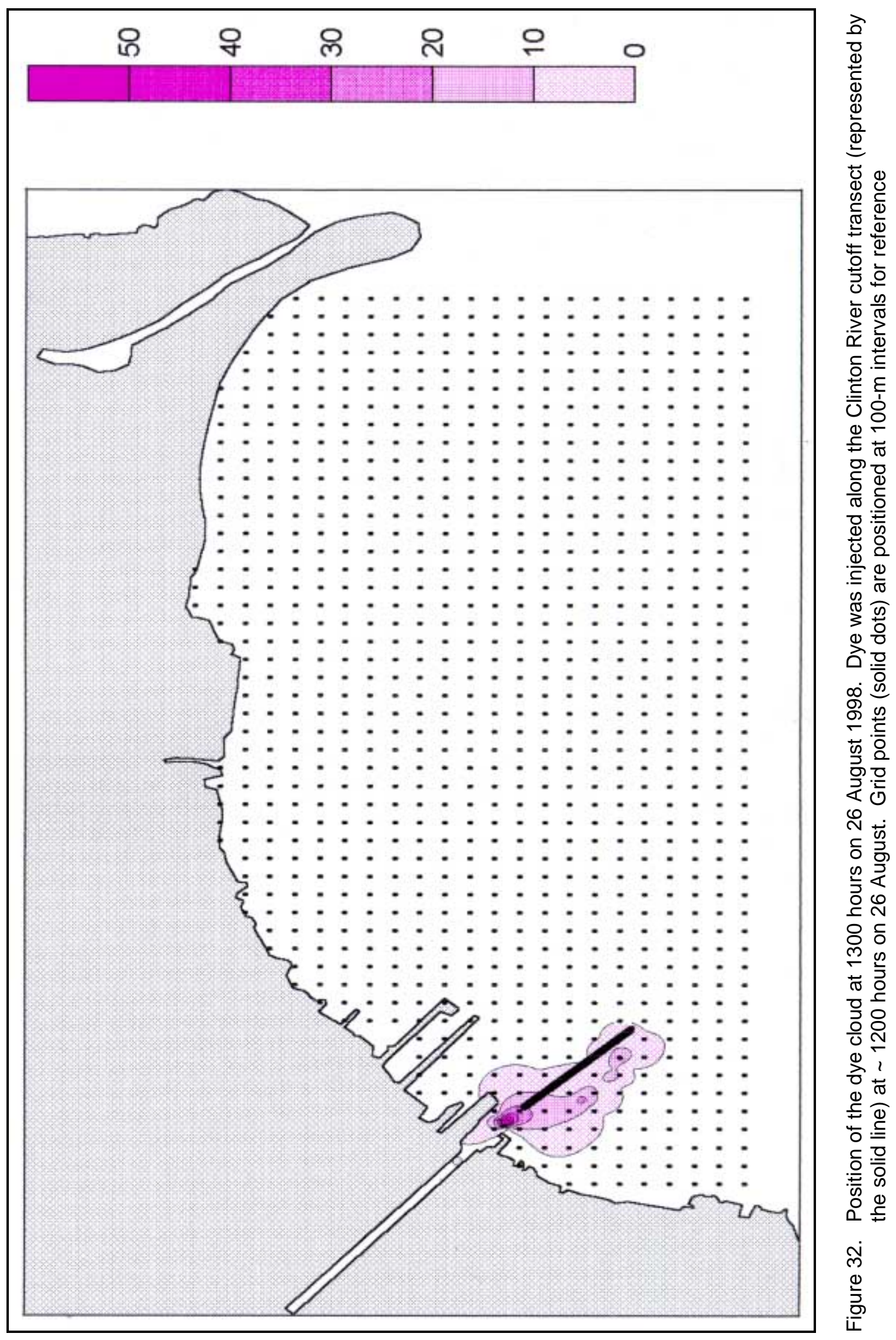




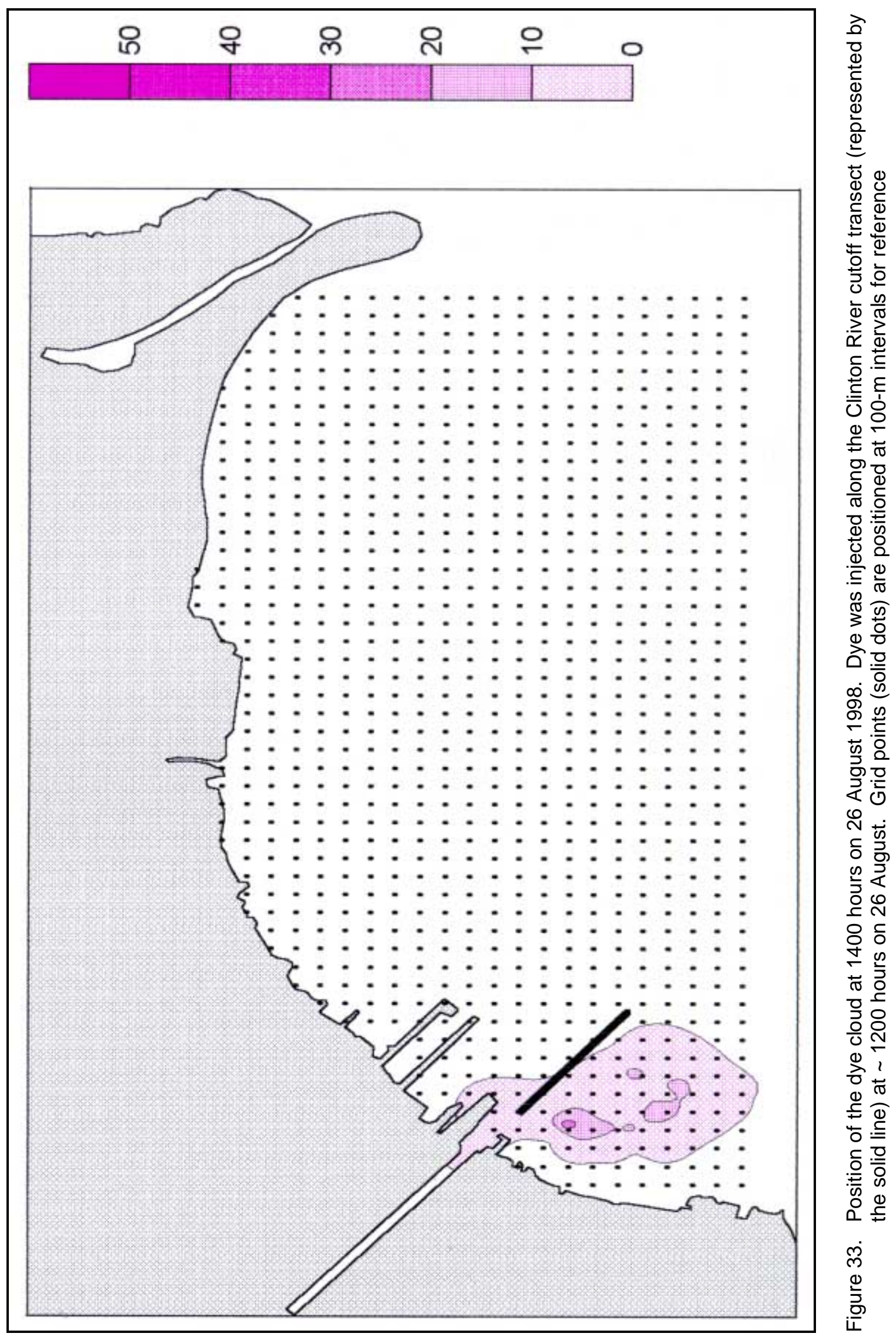




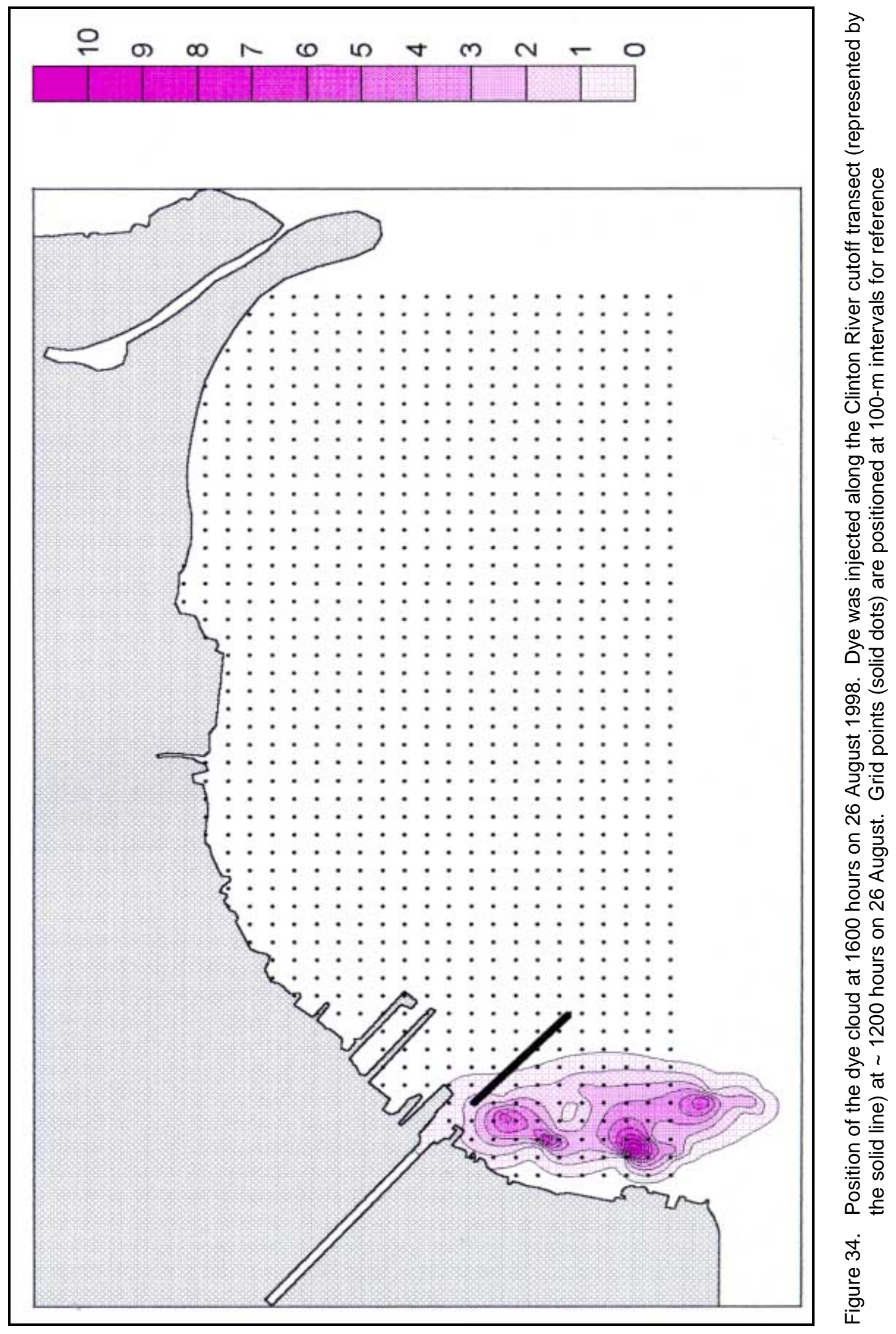




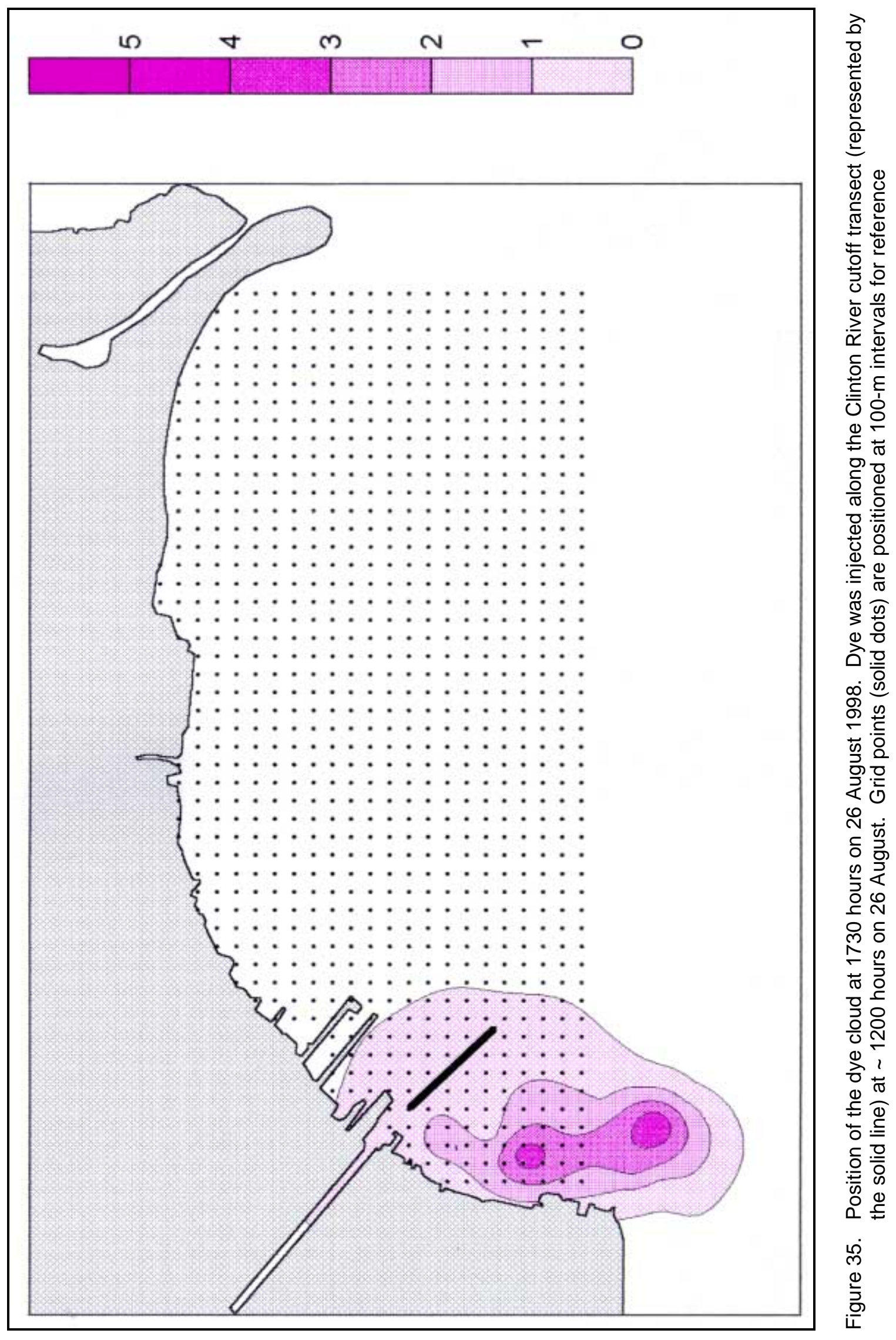




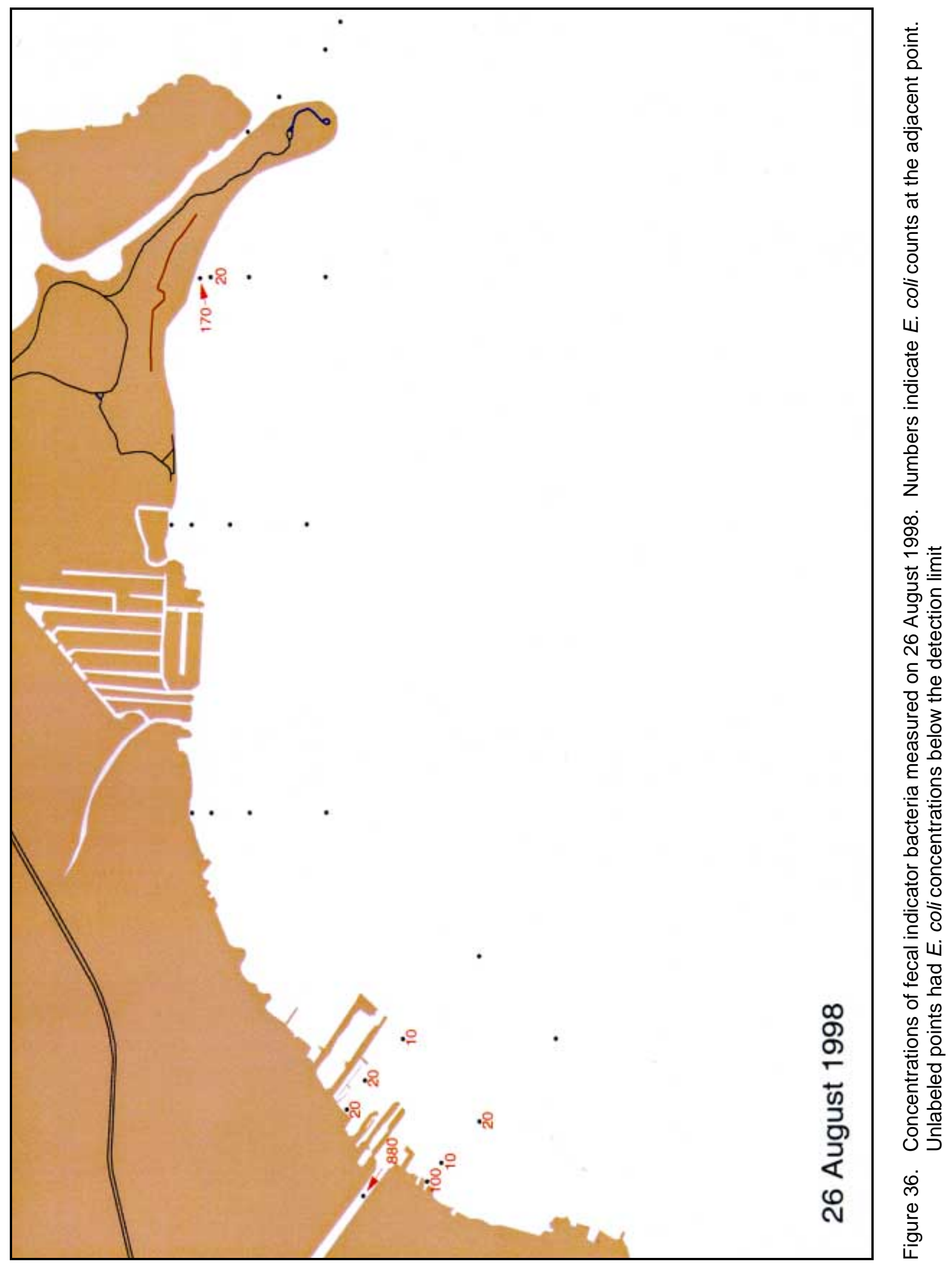




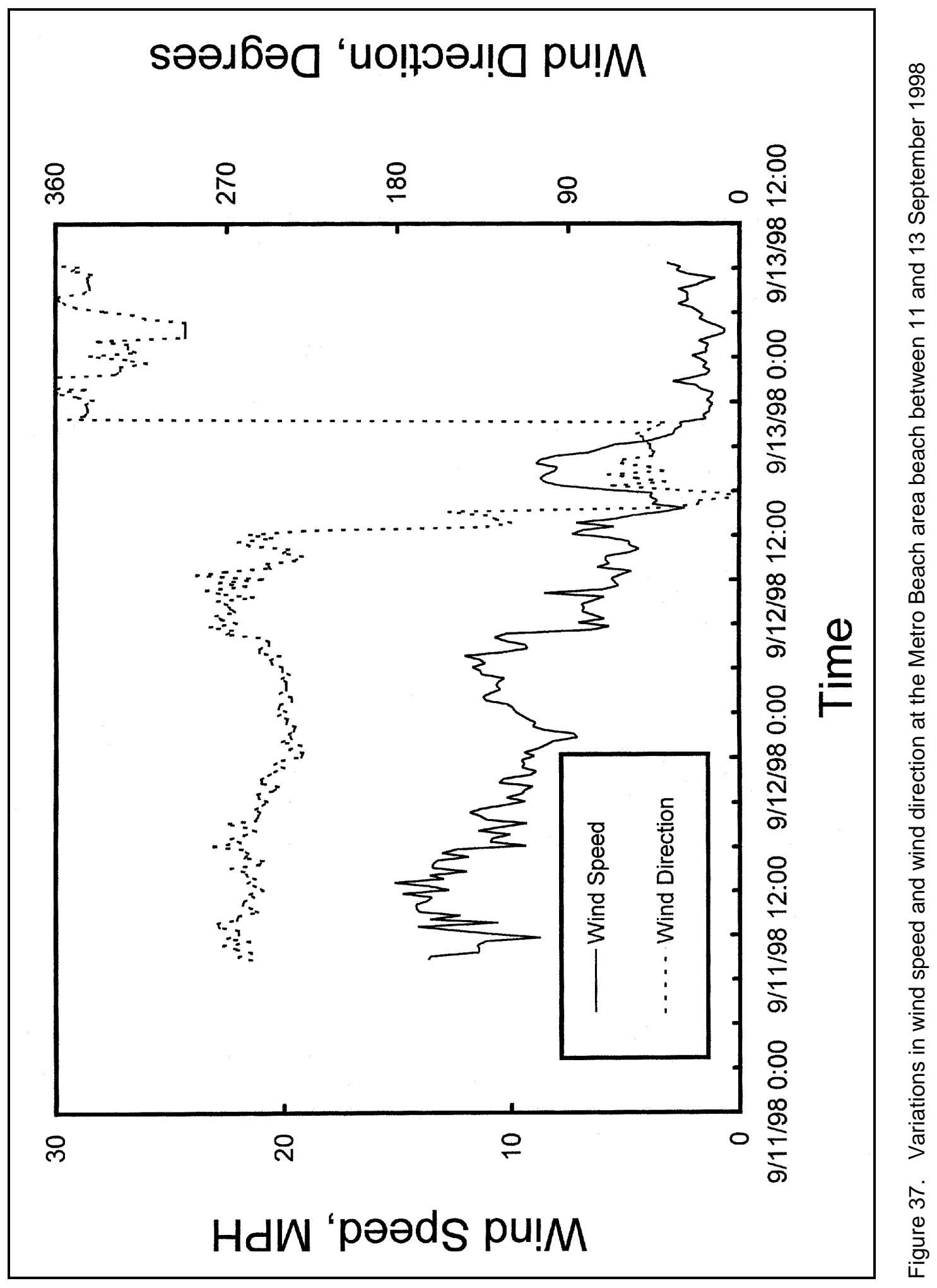




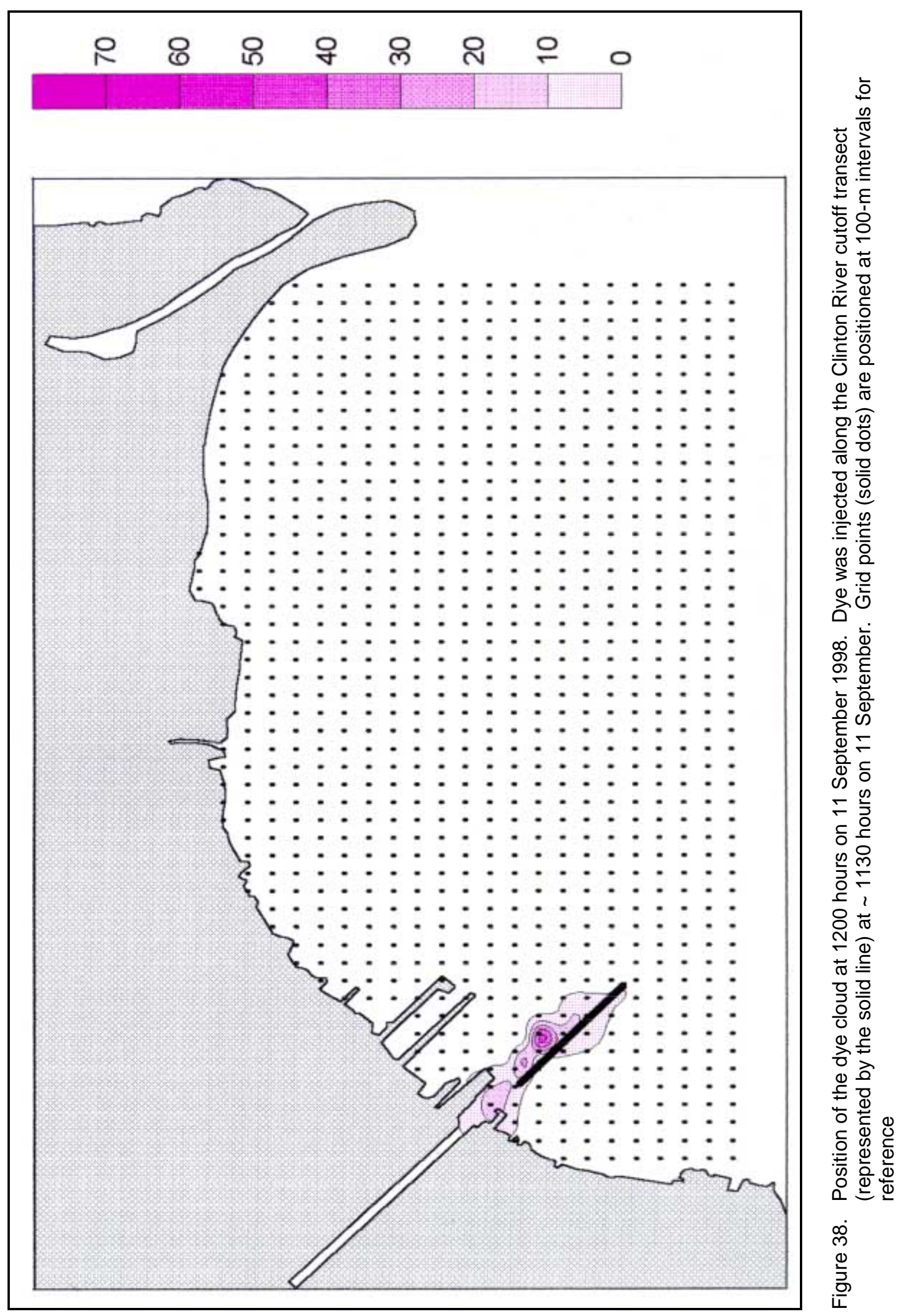




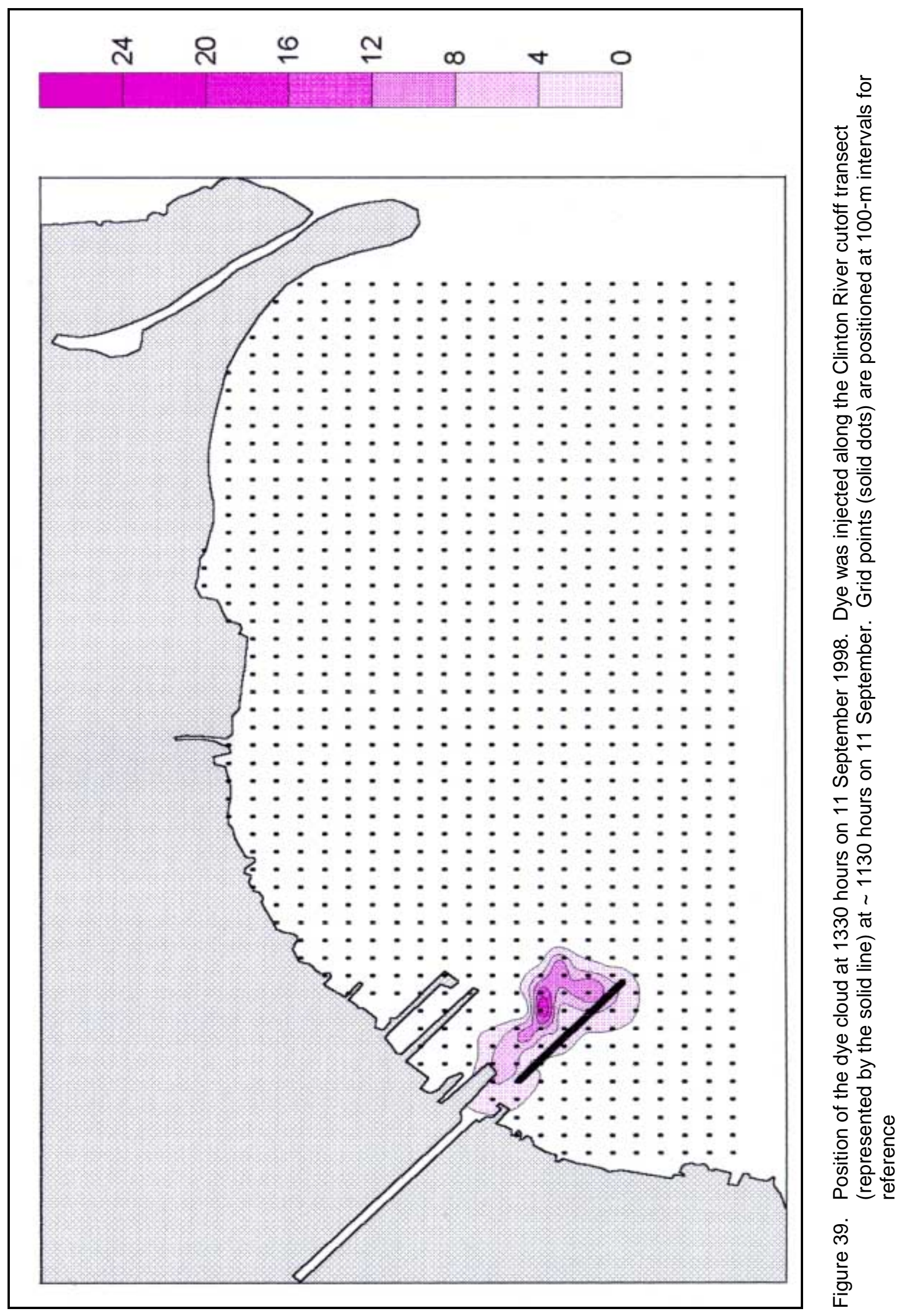




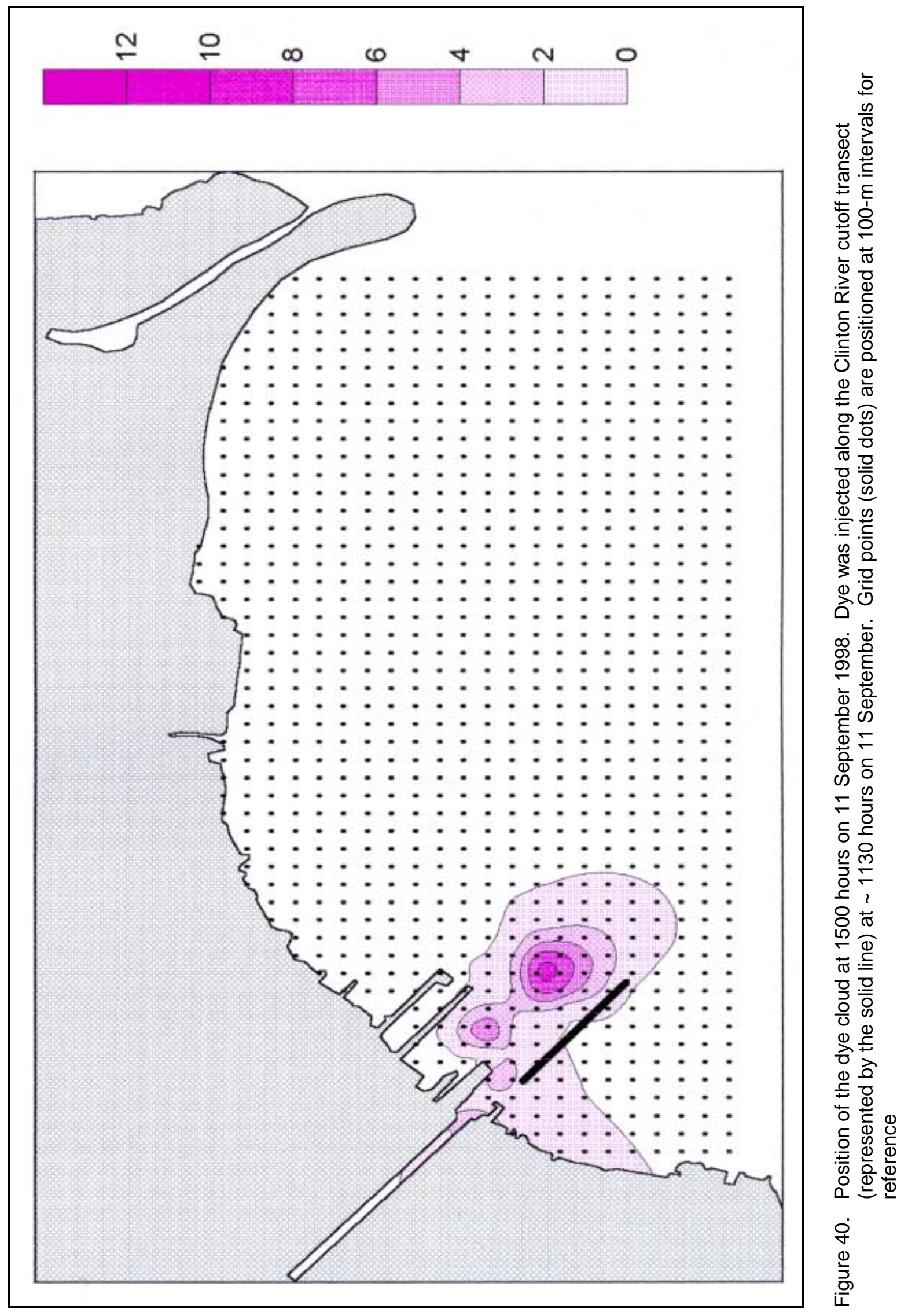




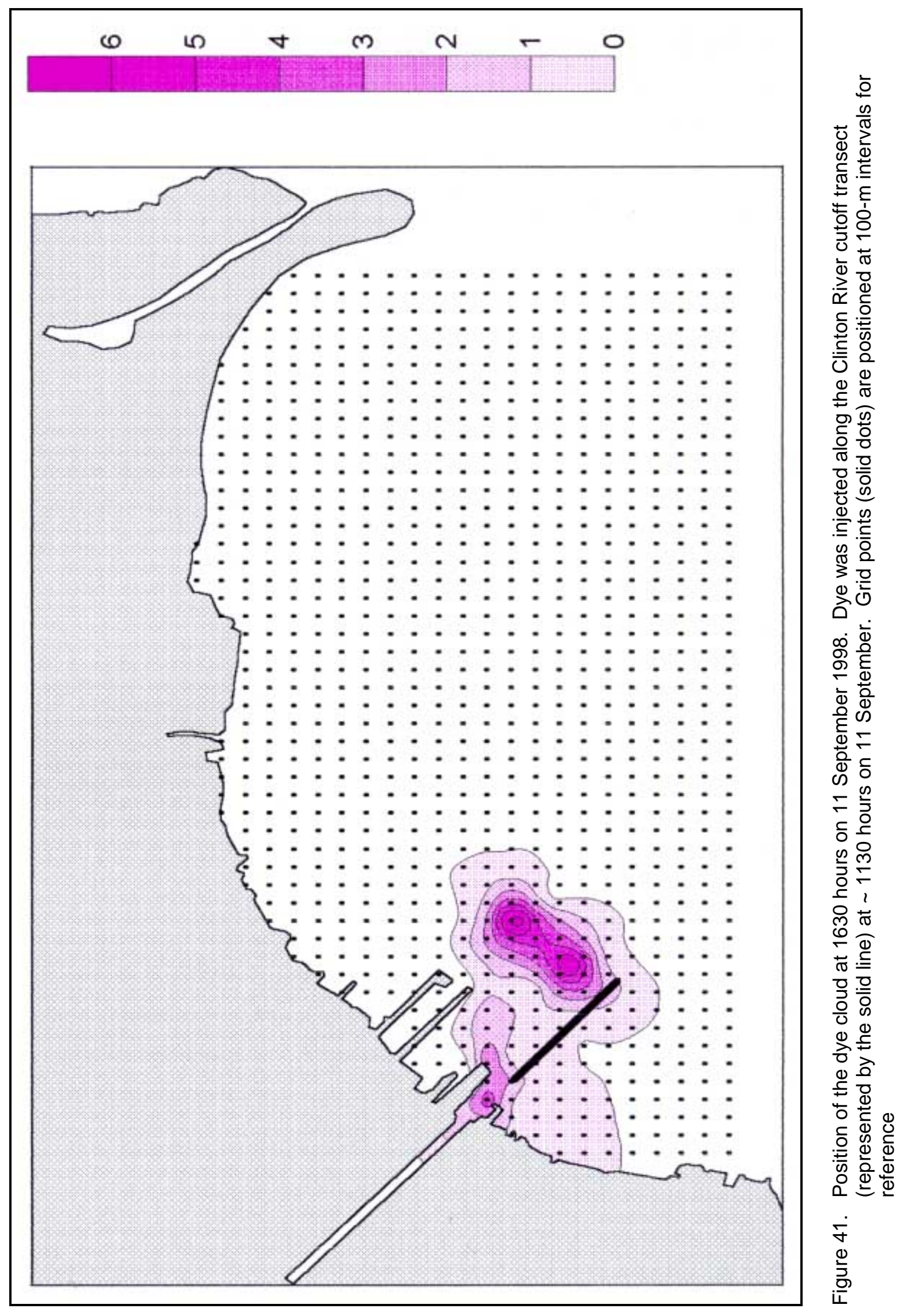




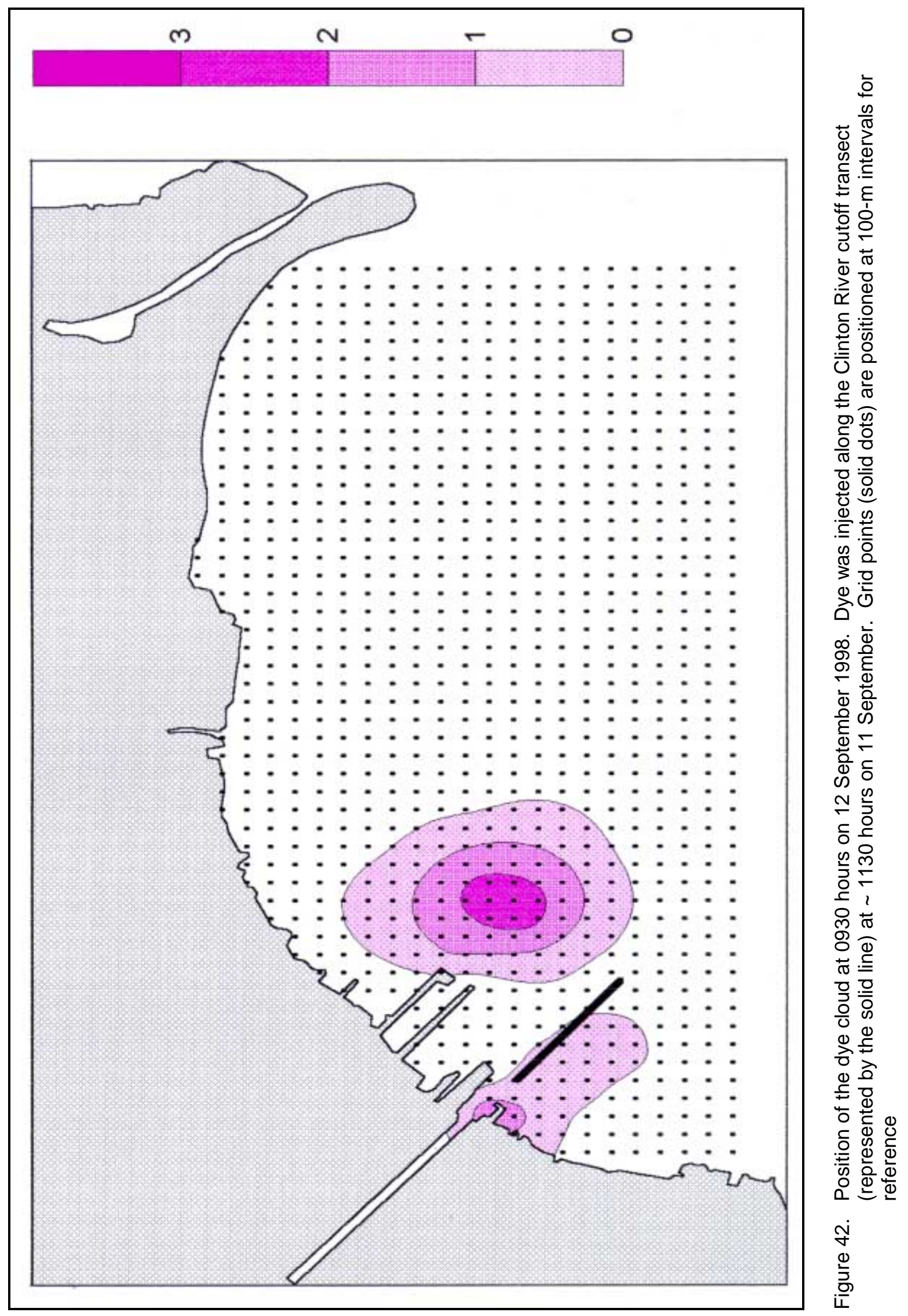




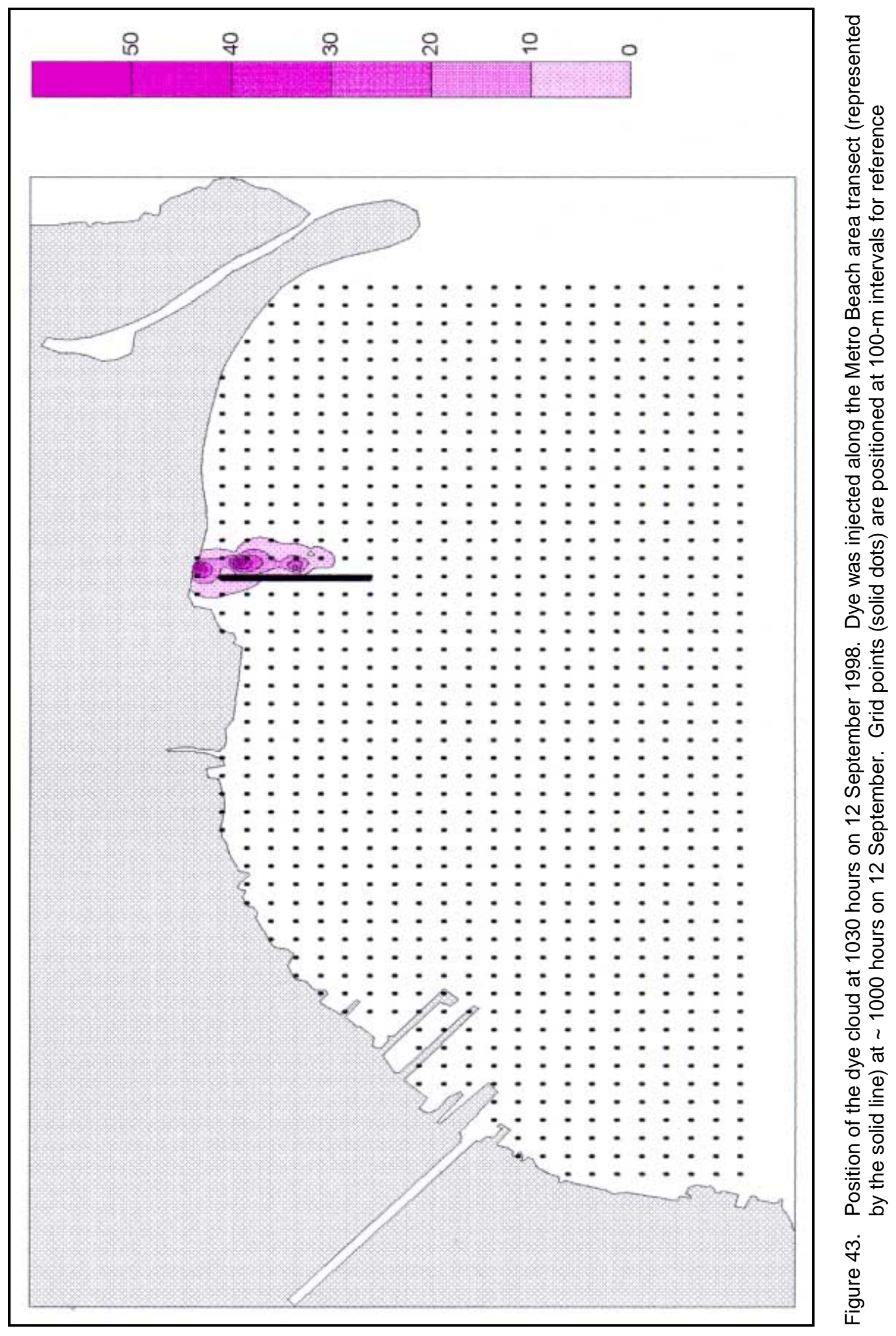




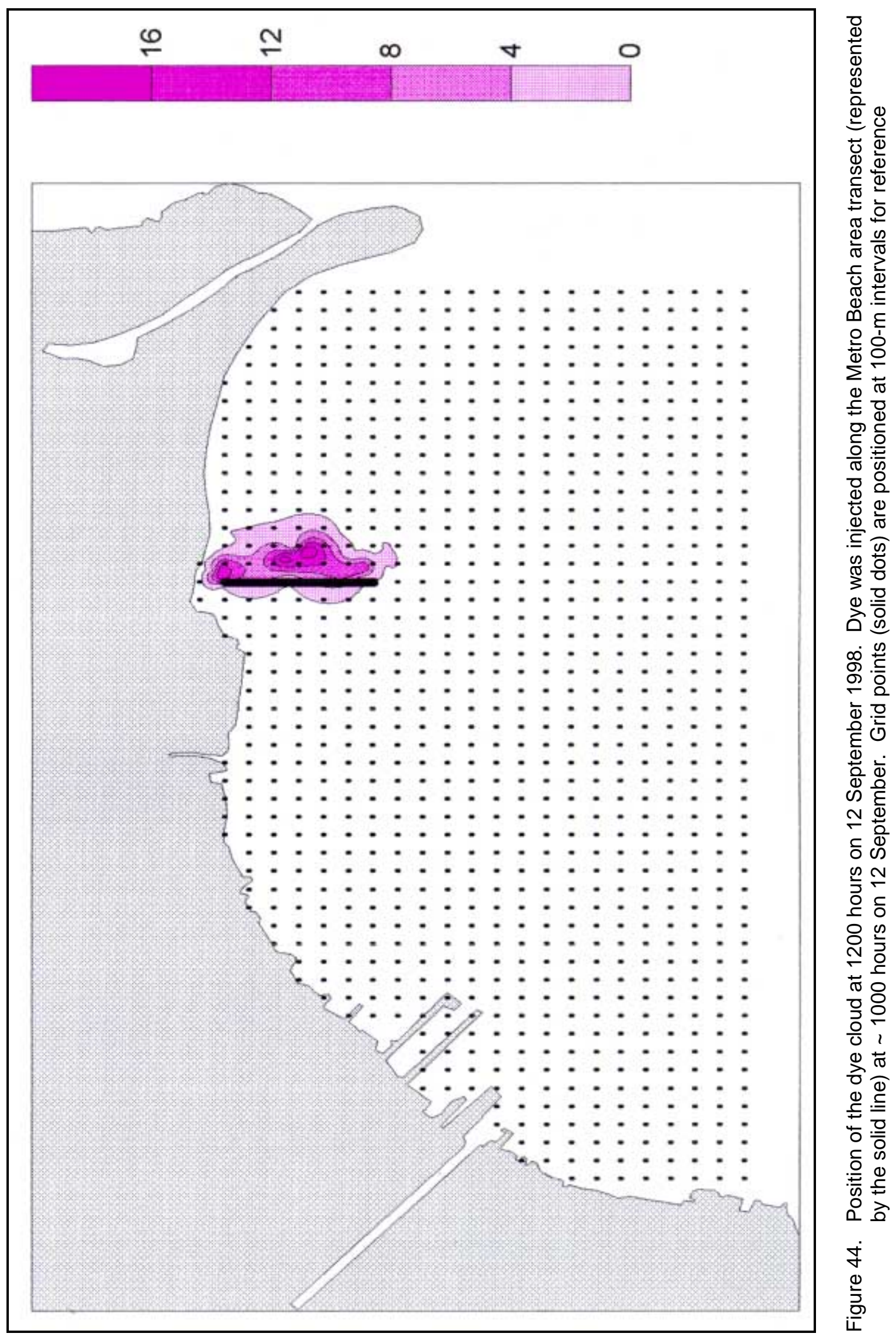




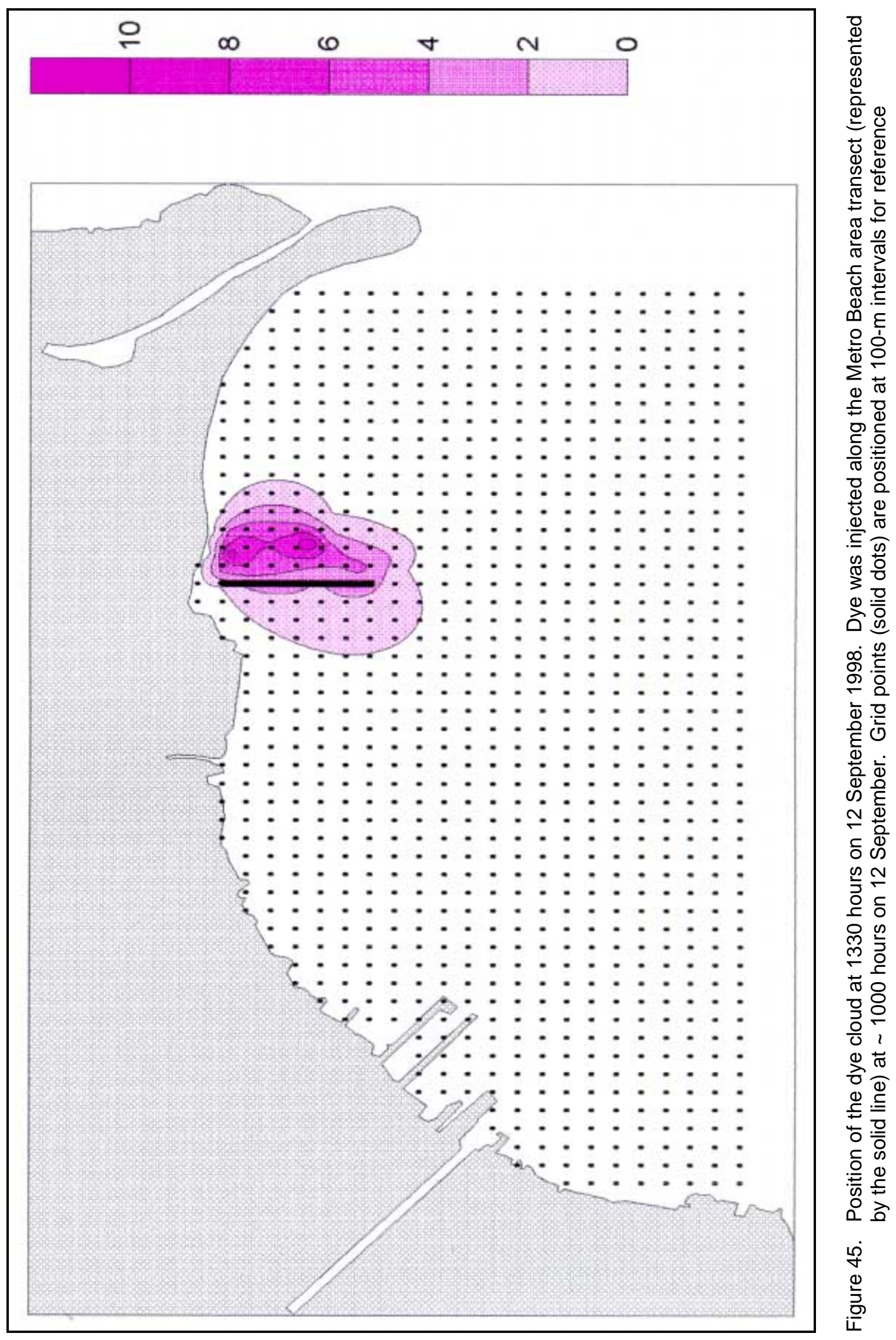




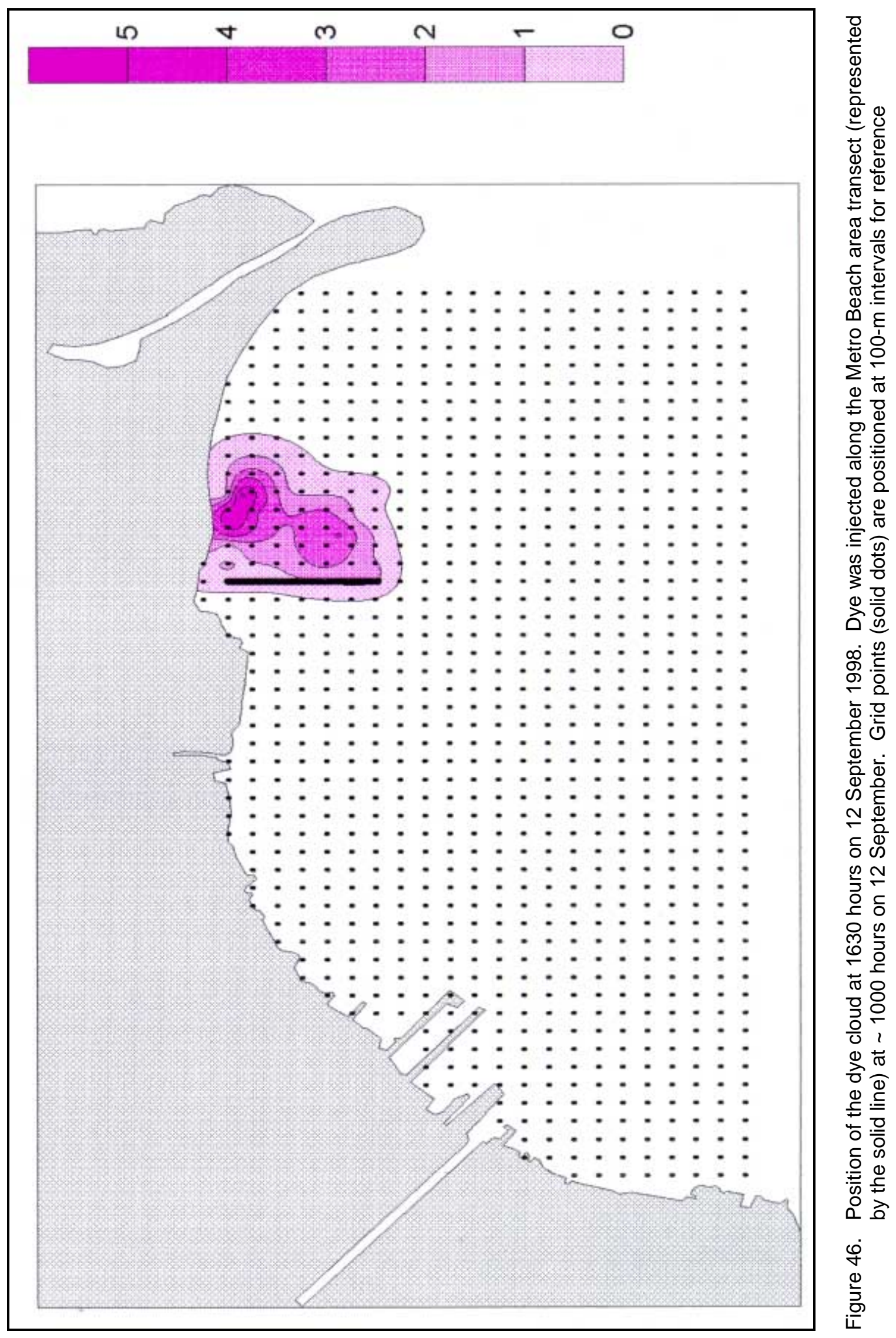




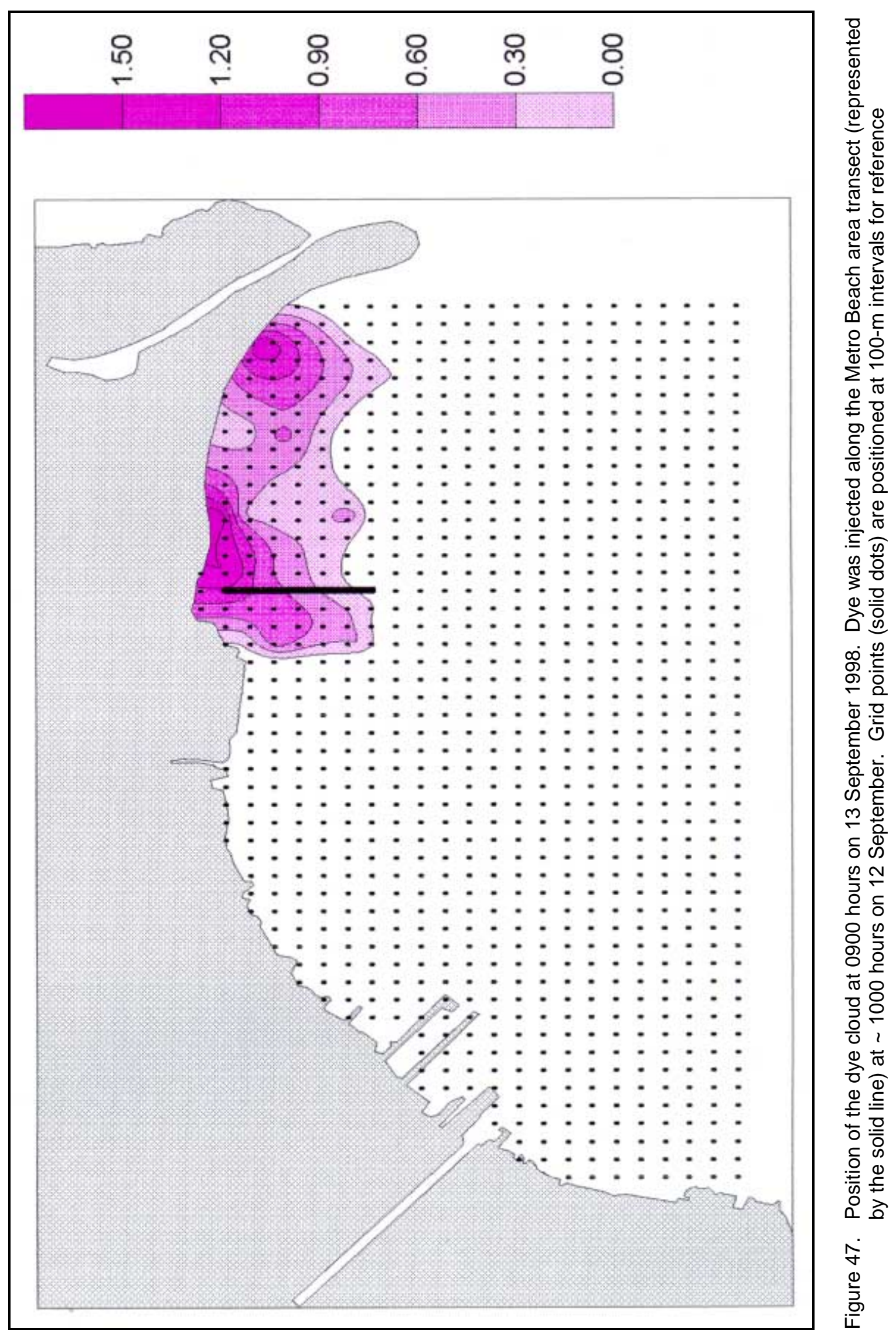




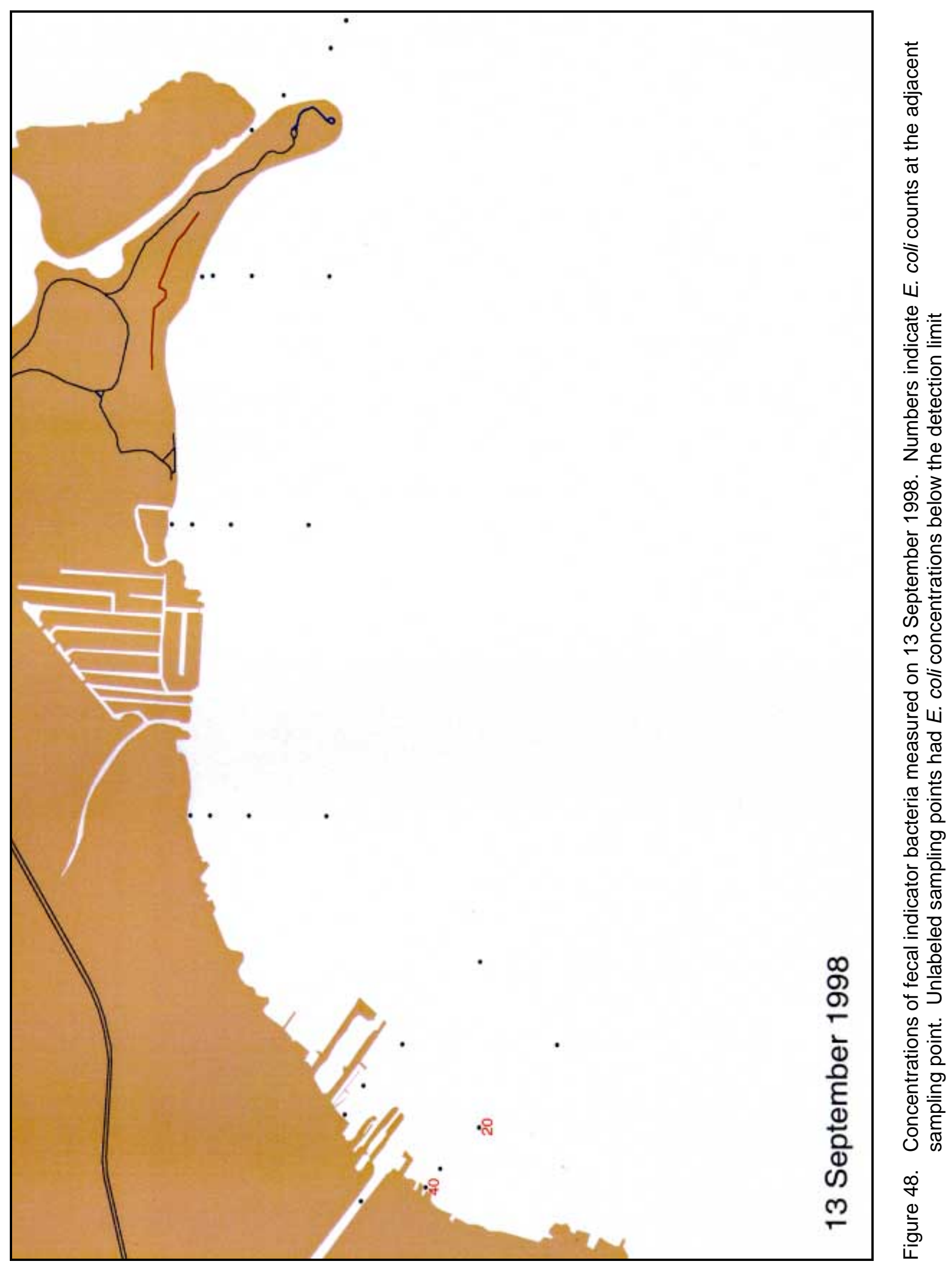




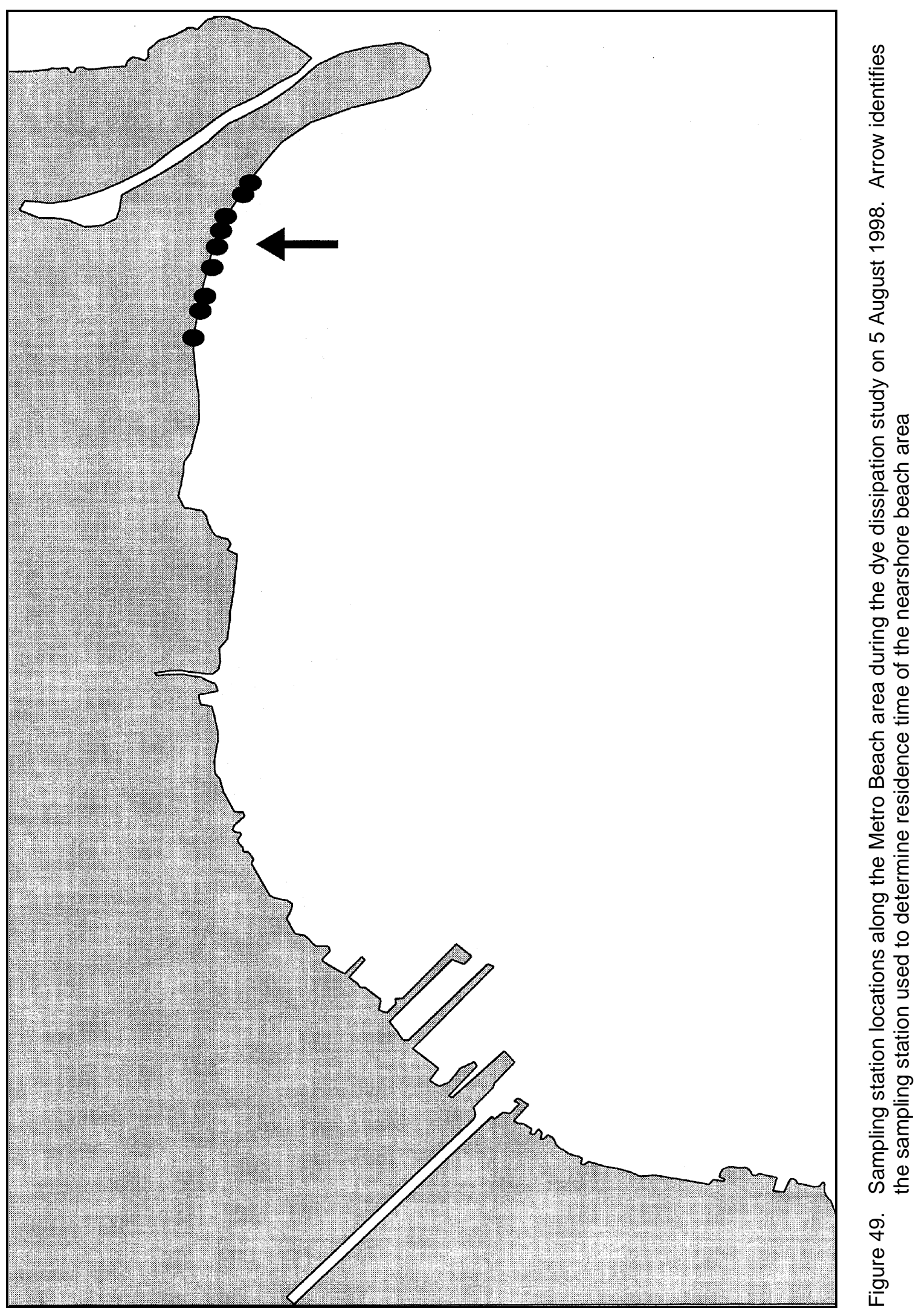




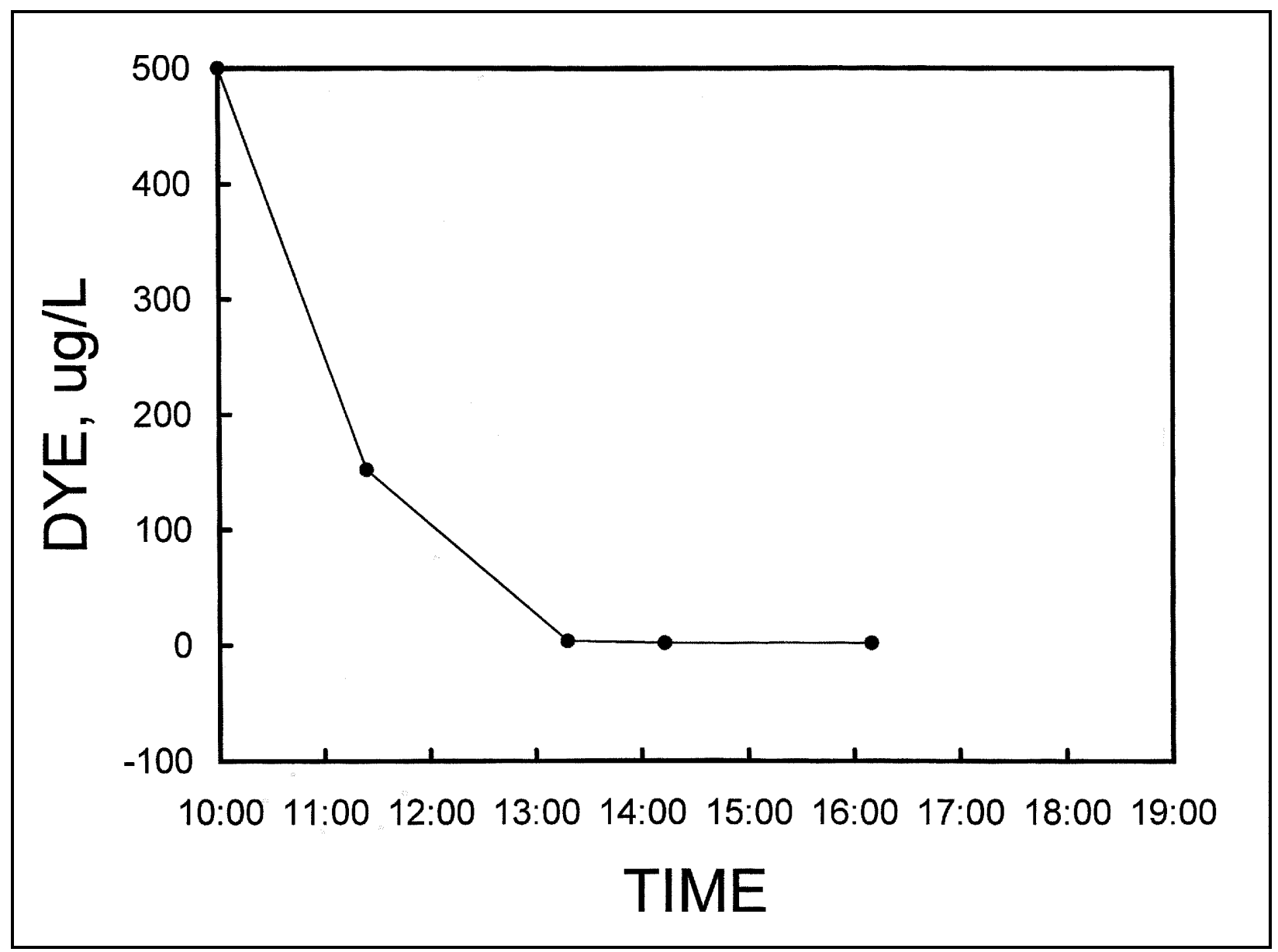

Figure 50. Changes in dye concentration as a function of time at the centrally located station (see

Figure 49) of the Metro Beach area dye dissipation study on 5 August 1998 


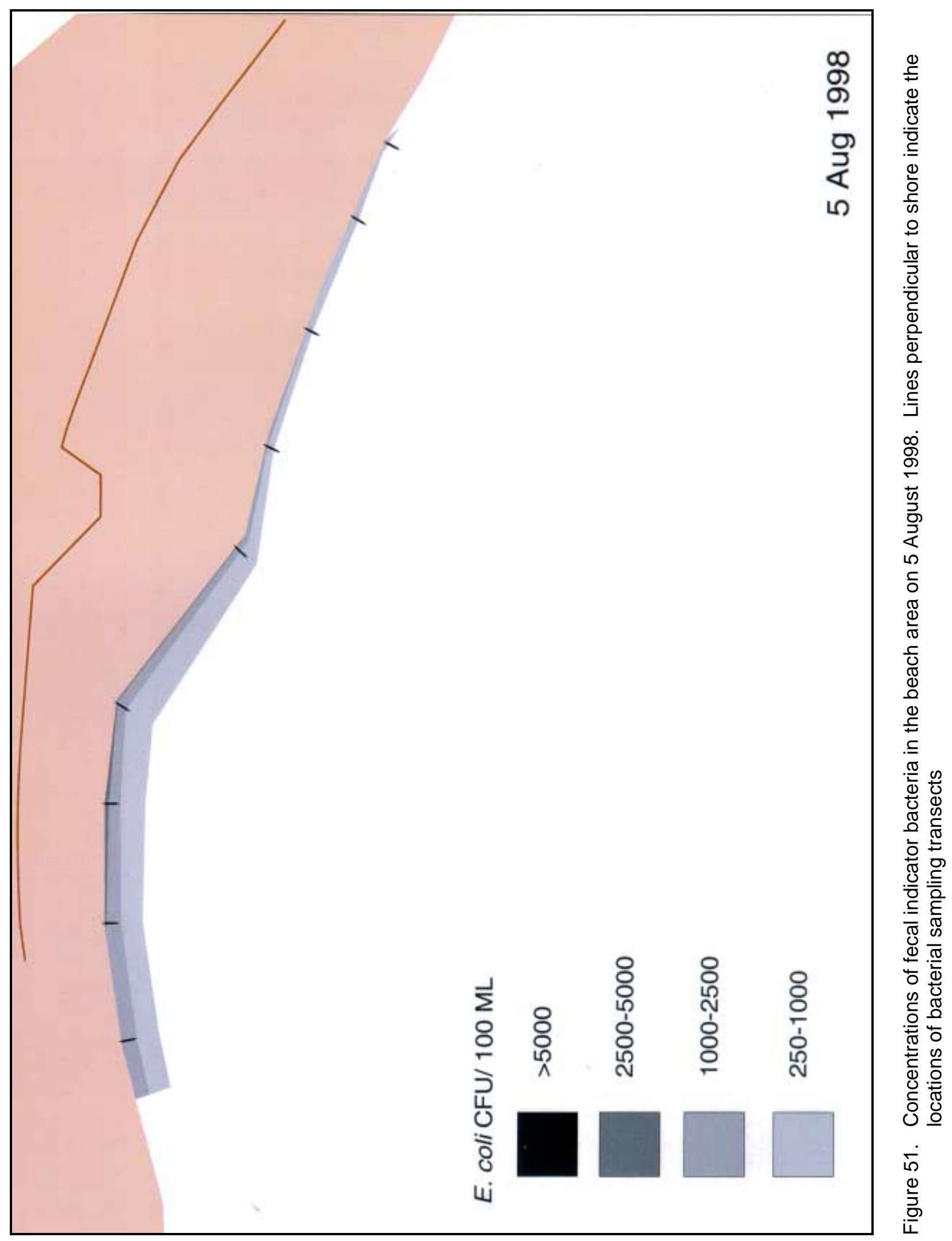




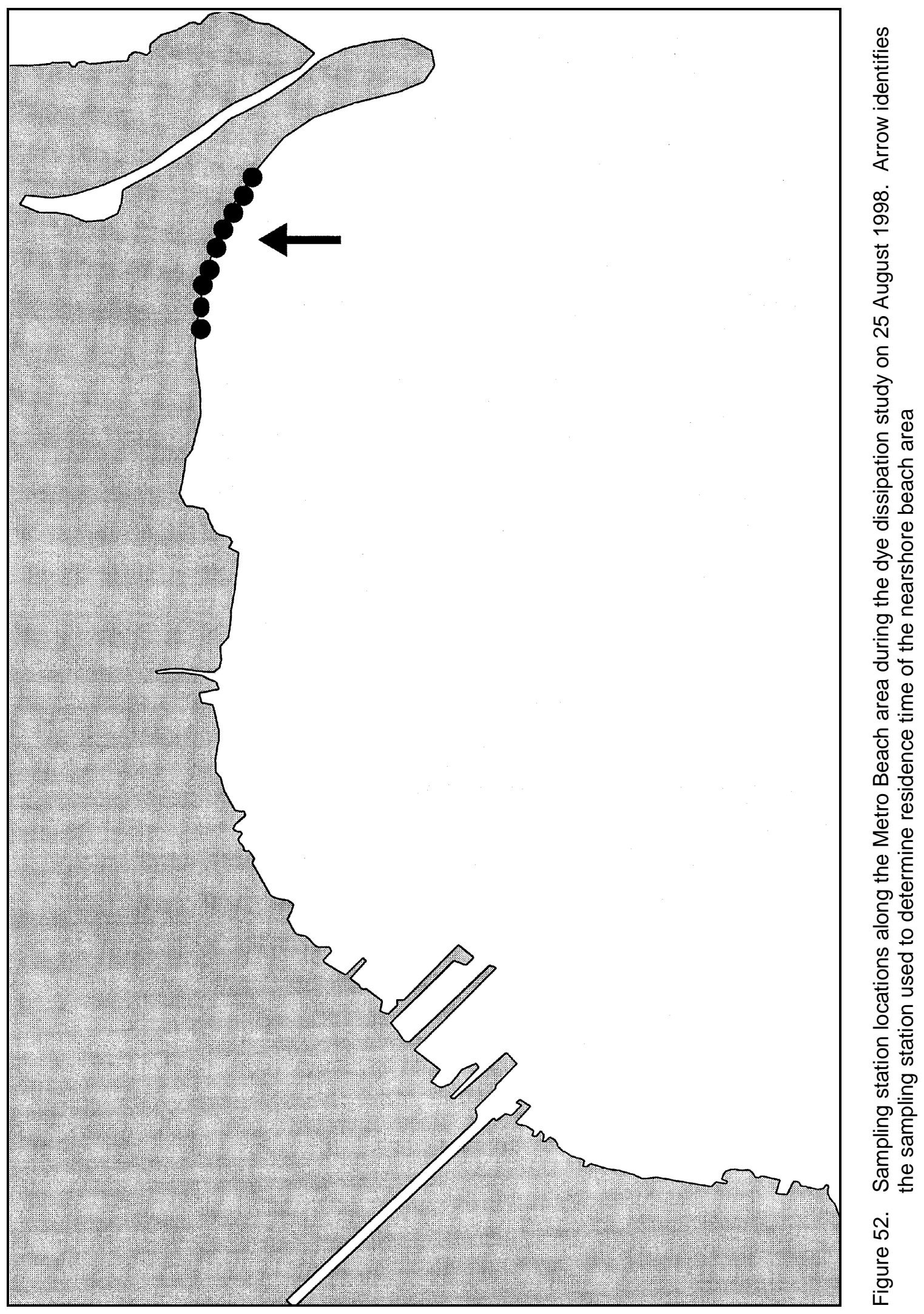




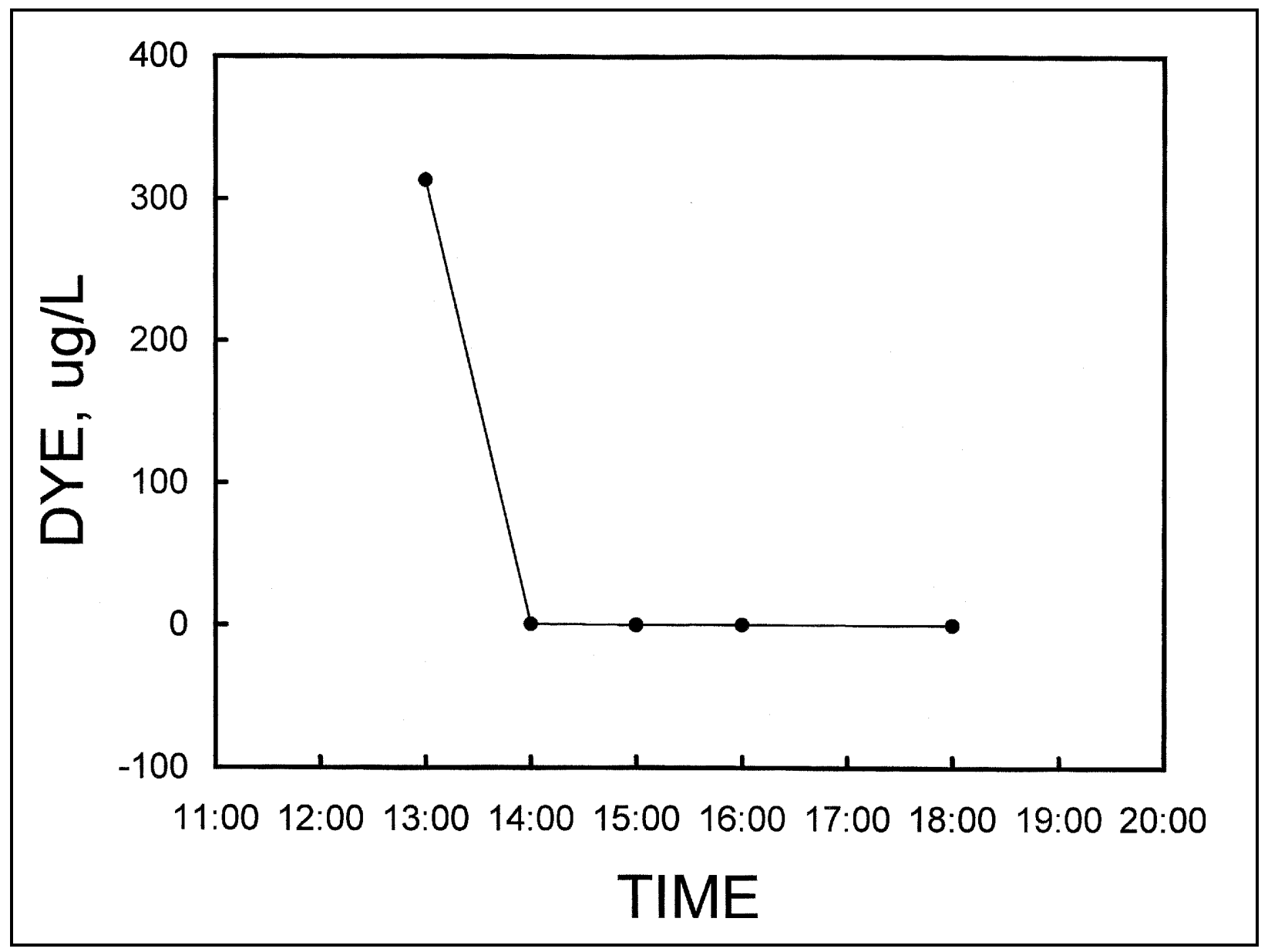

Figure 53. Changes in dye concentration as a function of time at the centrally located station (see Figure 52) of the Metro Beach area dye dissipation study on 25 August 1998 


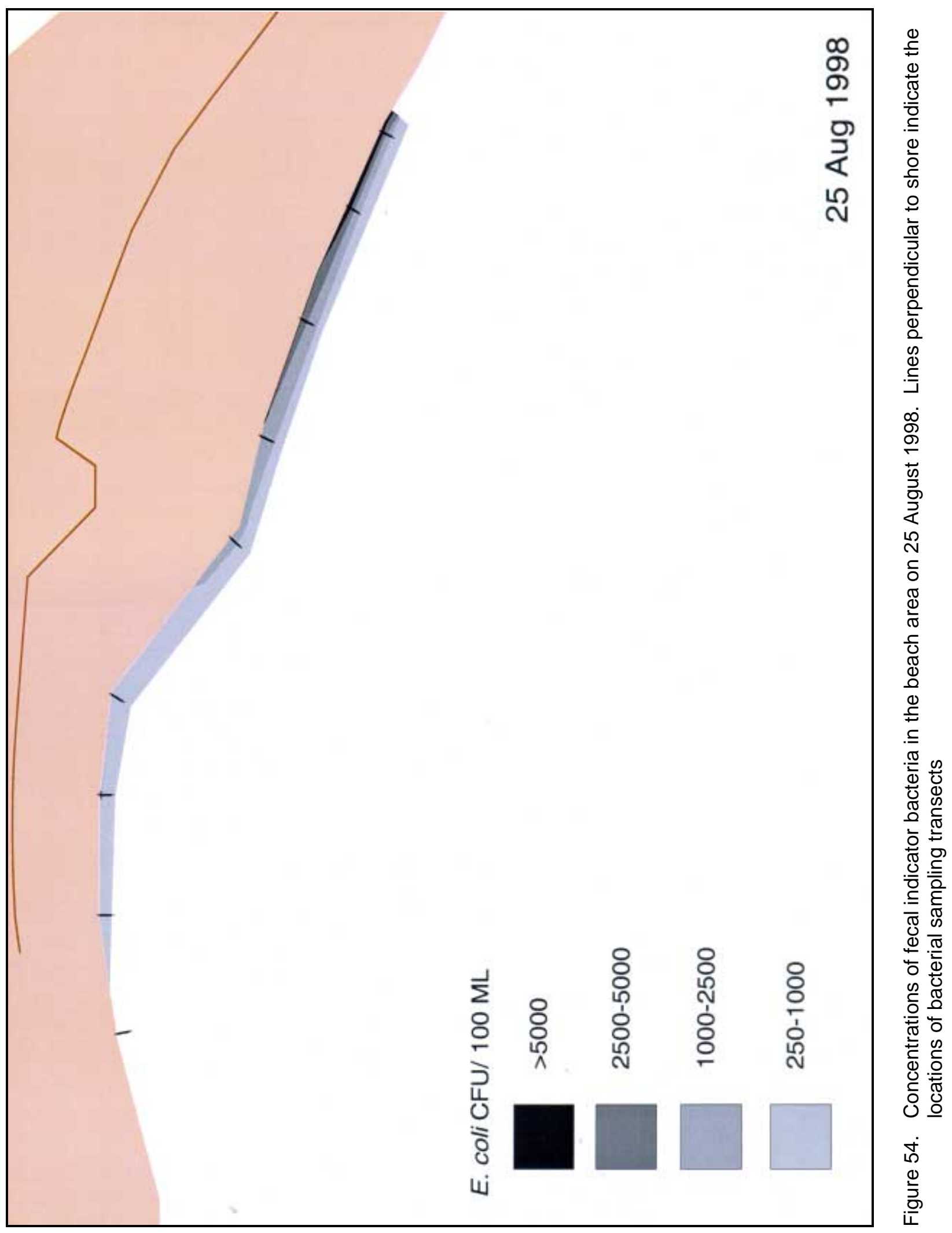




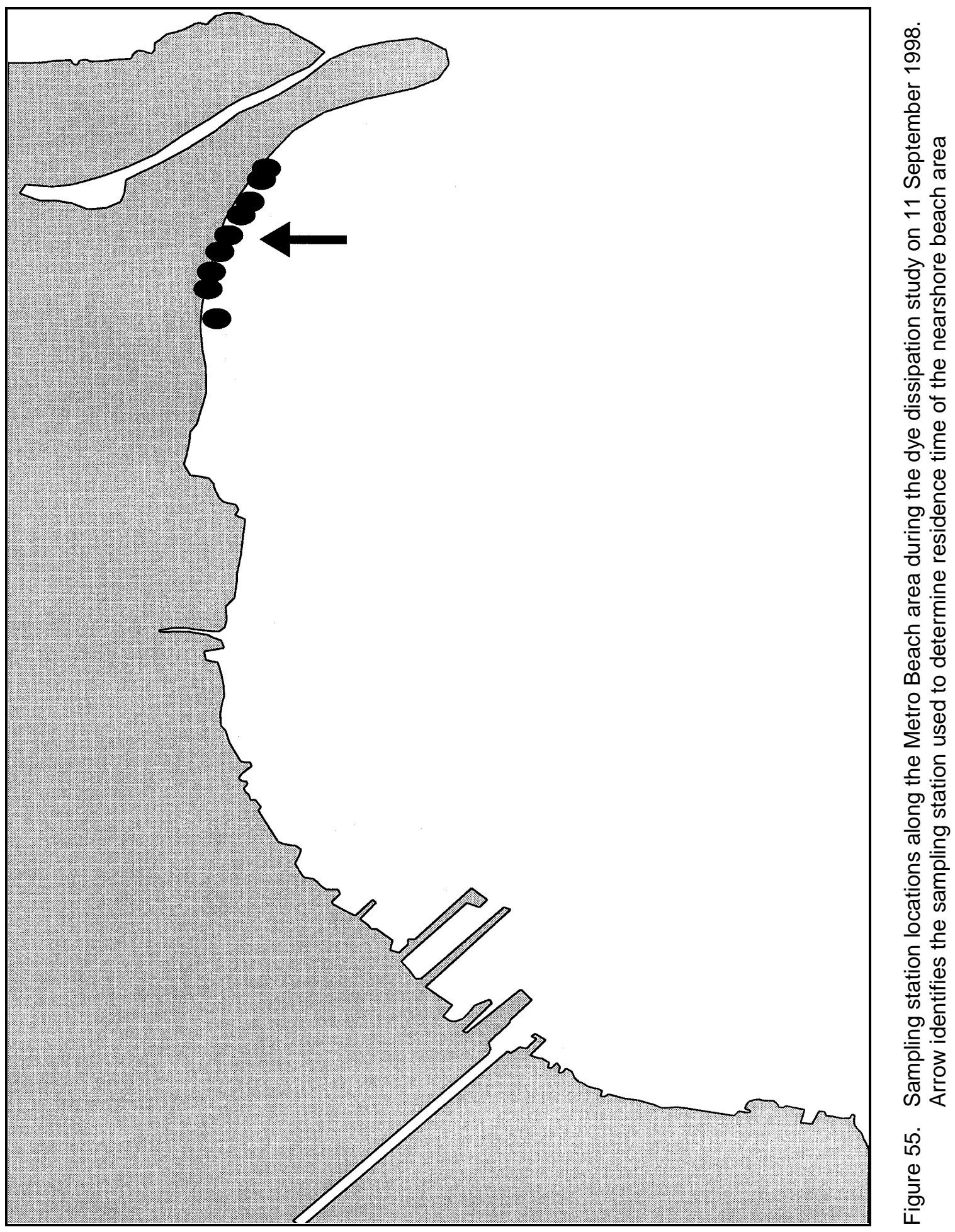




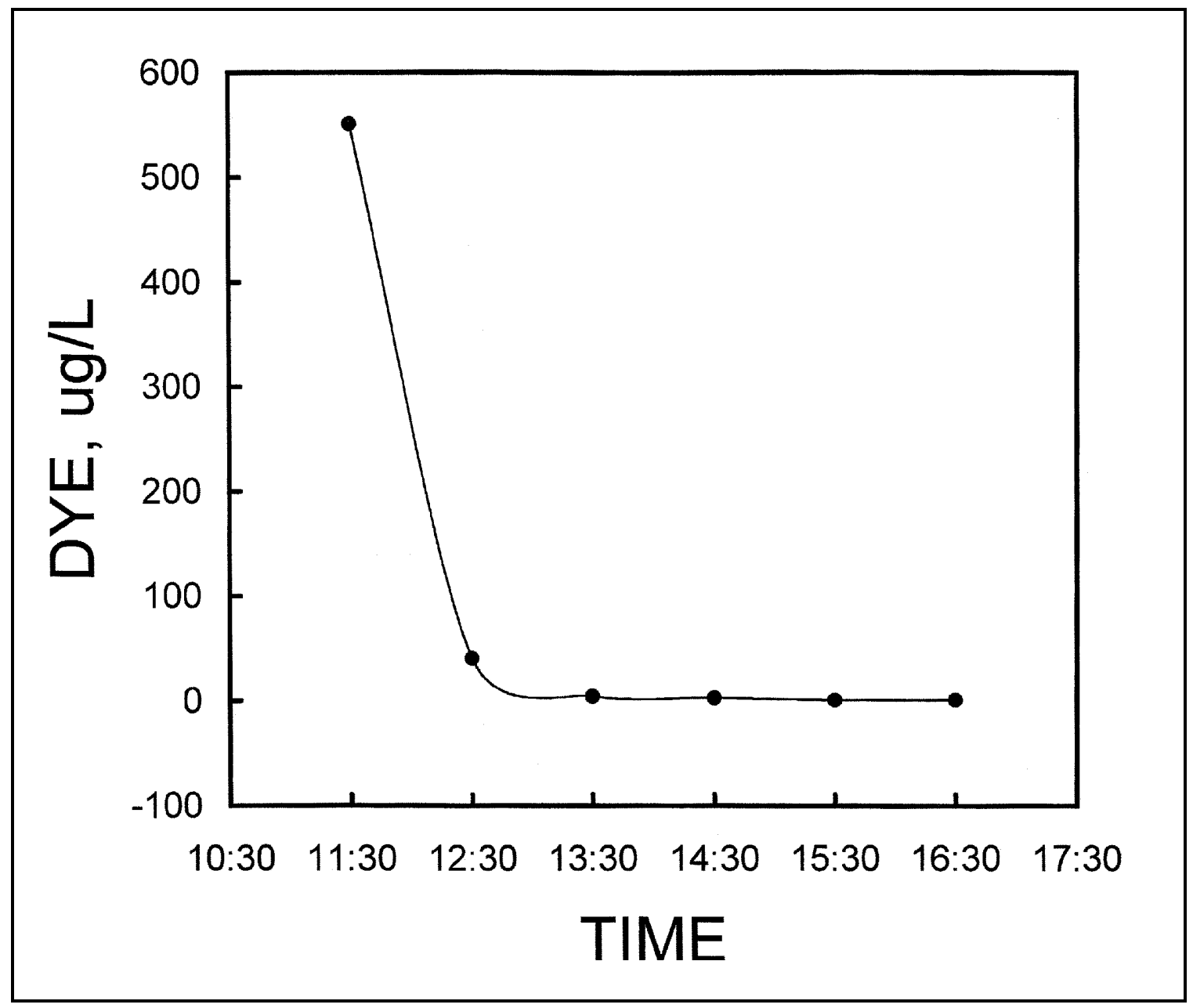

Figure 56. Changes in dye concentration as a function of time at the centrally located station (see Figure 55) of the Metro Beach area dye dissipation study on 11 September 1998 


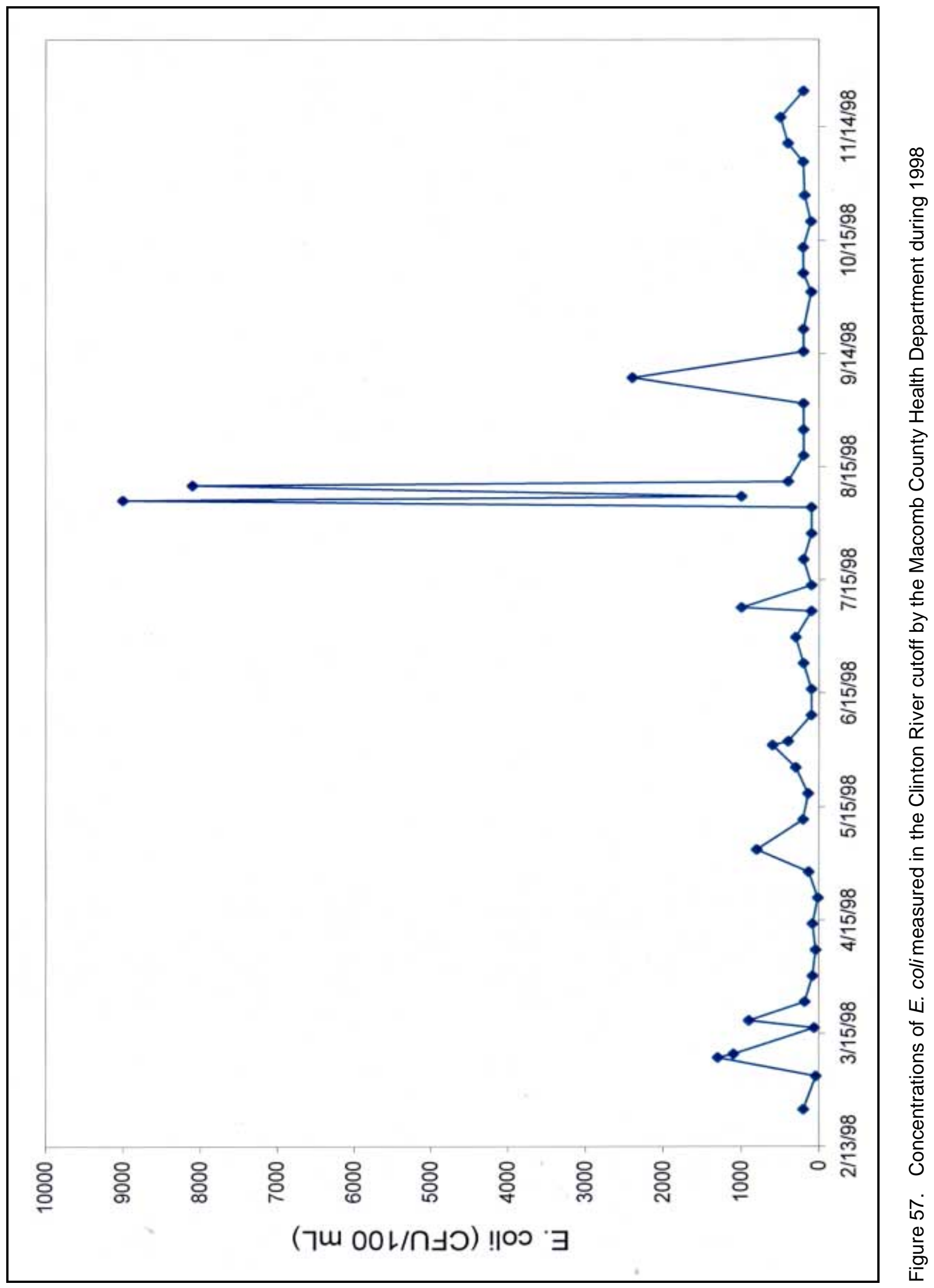




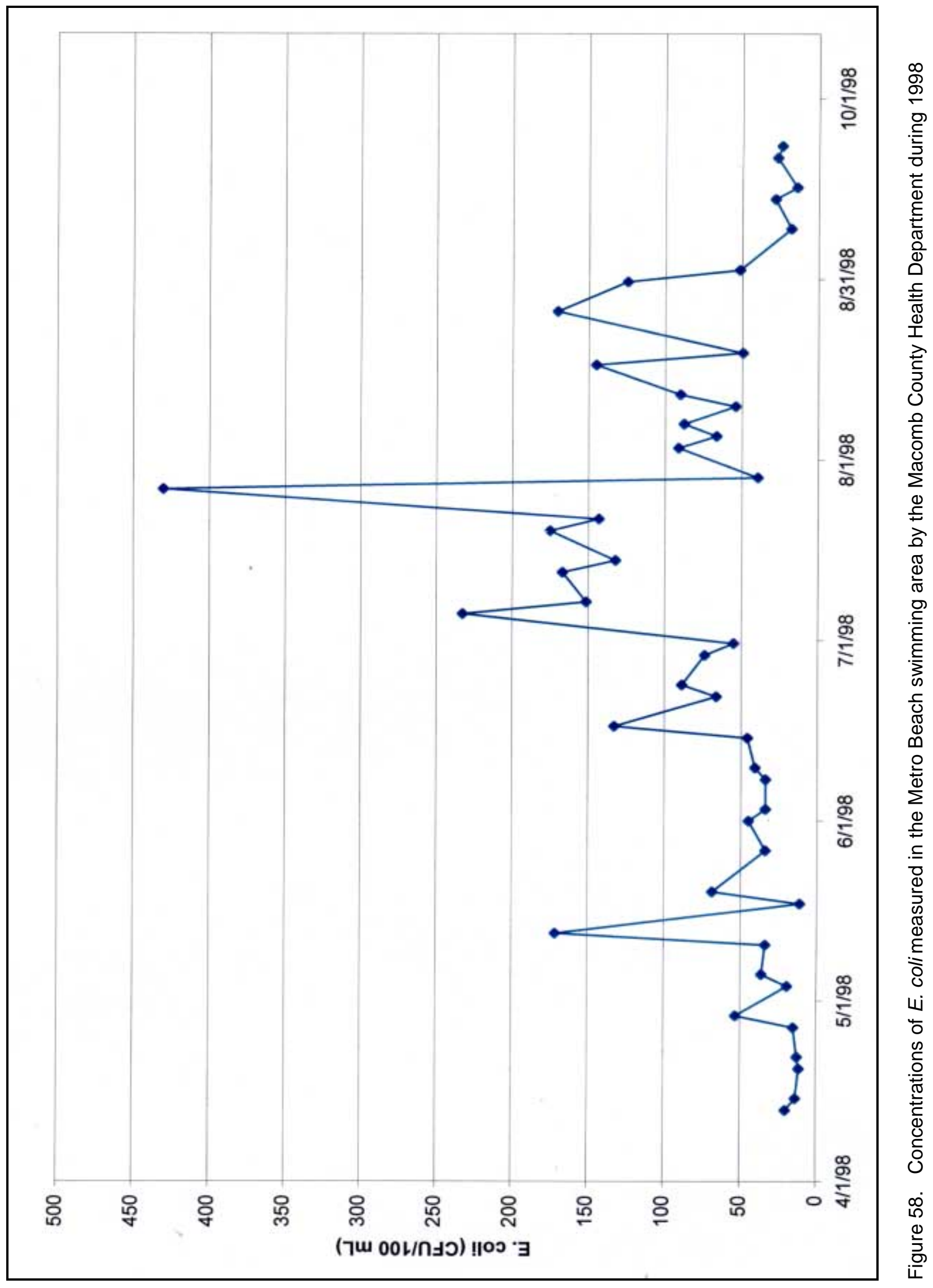




\section{REPORT DOCUMENTATION PAGE}

Public reporting burden for this collection of information is estimated to average 1 hour per response, including the time for reviewing instructions, searching existing data sources, gathering and maintaining

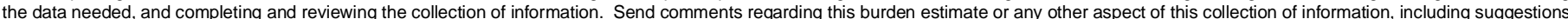

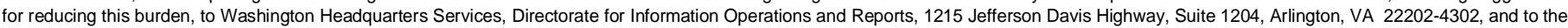
Office of Management and Budget, Paperwork Reduction Project (0704-0188), Washington, DC 20503.

\begin{tabular}{|l|c|c|}
\hline 1. AGENCY USE ONLY (Leave blank) & $\begin{array}{c}\text { 2. REPORT DATE } \\
\text { February } 2000\end{array}$ & $\begin{array}{c}\text { 3. REPORT TYPE AND DATES COVERED } \\
\text { Final report }\end{array}$ \\
\hline
\end{tabular}

\section{TITLE AND SUBTITLE}

Water Movement in Relation to Fecal Coliform Contamination in the Metro

Beach Area of Lake St. Clair, Michigan

5. FUNDING NUMBERS

$96 \times 3123$ O\&M

6. AUTHOR(S)

Craig S. Smith, William F. James, Harry L. Eakin, John W. Barko

7. PERFORMING ORGANIZATION NAME(S) AND ADDRESS(ES)

Professional Lake Management

8865 100th St. S.E.

Caladonia, MI 49316

U.S. Army Engineer Research and Development Center

Environmental Laboratory

3909 Halls Ferry Road, Vicksburg, MS 39180-6199

9. SPONSORING/MONITORING AGENCY NAME(S) AND ADDRESS(ES)

Headquarters, U.S. Army Corps of Engineers

10. SPONSORING/MONITORING AGENCY REPORT NUMBER

Washington, DC 20314-1000

\section{SUPPLEMENTARY NOTES}

Available from National Technical Information Service, 5285 Port Royal Road, Springfield, VA 22161.

12a. DISTRIBUTION/AVAILABILITY STATEMENT

12b. DISTRIBUTION CODE

Approved for public release; distribution is unlimited.

13. ABSTRACT (Maximum 200 words)

The purpose of this investigation was to determine sources of fecal coliform bacteria contaminating the Metro Beach area of Lake St. Clair and the likelihood that water currents moved contaminated water from the Clinton River cutoff into the Metro Beach area rapidly enough and with sufficiently limited dilution that bacteria from this source would exceed Michigan state standards for body contact recreation. Rhodamine WT, a red fluorescent dye, was used as a tracer for monitoring water movement near the Metro Beach area of Lake St. Clair during the weeks of 1 June, 13 July, 3 August, 24 August, and 7 September, 1998. The dye was injected into the upper $1 \mathrm{~m}$ of the water column near these locations along transects that were established perpendicular to the shoreline and approximately $600 \mathrm{~m}$ in length. Dye cloud movement from each transect was tracked at $\sim 2$-hour intervals over a 12- to 24-hour period. In conjunction with water movement studies, bacterial sampling transects, established perpendicular to the shore, were located between the Clinton River cutoff and the Metro Beach area. Along each transect, samples were collected at distances of approximately 100, 300, and 700-1000 m from shore. Bacterial samples were also taken from the mouth of the Clinton River Spillway. Dye dissipation studies and bacterial sampling were also conducted along the Metro Beach during the weeks of 3 and 24 August and 7 September, as mounting evidence indicated that bacterial contamination might be a localized nearshore phenomenon.

(Continued)

14. SUBJECT TERMS

Fecal Coliform Bacteria

Swimming Beaches, Lake St. Clair

Water circulation
15. NUMBER OF PAGES

87

16. PRICE CODE

\begin{tabular}{|l|l|l|} 
17. SECURITY CLASSIFICATION \\
$\begin{array}{l}\text { OF REPORT } \\
\text { UNCLASSIFIED }\end{array}$ & $\begin{array}{c}\text { 18. SECURITY CLASSIFICATION } \\
\text { OF THIS PAGE } \\
\text { UNCLASSIFIED }\end{array}$ & $\begin{array}{c}\text { 19. SECURITY CLASSIFICATION } \\
\text { OF ABSTRACT }\end{array}$ \\
\hline
\end{tabular}

NSN 7540-01-280-5500
Standard Form 298 (Rev. 2-89)

Prescribed by ANSI Std. Z39-18 298-102 


\section{3. (Concluded).}

Water currents in the part of Lake St. Clair between Metro Beach and the Clinton River cutoff were predominantly driven by wind direction and speed. In particular, winds blowing out of the west and southwest resulted in water circulation that followed an easterly trajectory toward the beach area. During the summer of 1998,winds blew out of the westerly wind rose (i.e., NW and SW wind rose) 62 percent of the time. Thus water movement from the mouth of the cutoff toward Metro Beach would have been expected to dominate circulation patterns from April until September. One possible source of fecal coliform contamination in the Metro Beach area was contaminated Clinton River water from the cutoff, transported to the beach by these water currents generated due to winds blowing out of the westerly wind rose. In order for this mechanism to operate, three conditions must be met: (1) the Clinton River cutoff must carry water with a high concentration of bacteria, (2) the flow of contaminated water from the Clinton River cutoff must be sufficient to produce a mass of contaminated water in the lake, and (3) water circulation must move the contaminated water mass from the cutoff to the beach rapidly enough so that the bacteria remain viable. However, these conditions were rarely met during the summer of 1998 . Despite low flows from the Clinton River cutoff in 1998 and low bacterial concentrations in the area between the cutoff and Metro Beach, E. coli concentrations were often elevated in the immediate vicinity of the beach.

Bacterial concentrations along the beach transects were consistently highest close to shore, suggesting that bacteria were entering the lake directly from the beach. Bacterial concentration patterns observed near the beach during dye studies indicated relatively low bacterial concentrations in the water on the upstream end of the beach, which increased toward the downstream end of the beach. This pattern suggests that relatively clean water from the lake was becoming contaminated as it passed by the beach.

Relatively high levels of bacterial contamination in the beach area were attained despite the brief residence time of water in the area, indicating that the beach must be a substantial source of bacteria. The source of bacteria contaminating the beach was not positively identified, but large numbers of gulls and geese congregate on the beach at night, and their droppings are the most likely source. The results of this study provide very strong evidence that bacterial contamination of the beach at Metro Beach is an important source of bacterial contamination in the swimming area. 
Destroy this report when no longer needed. Do not return it to the originator. 